\title{
Computational Analysis of the SRS Phase III Salt Disposition Alternatives
}

by

R. A. Dimenna

Westinghouse Savannah River Company

Savannah River Site

Alken, South Carolina 29808

M. V. Gregory

T. Hang

P. K. Paul

F. G. Smith III

G. A. Taylor

DOE Contract No. DE-AC09-96SR18500

This paper was prepared in connection with work done under the above contravt number with the U.S.

Department of Energy. By acceptance of this paper, the publisher and/or recipjent acknowledges the U.S. Government's right to retain a nonexclusive, royalty-free license in and to any copyright covering this paper, along with the right to reproduce and to authorize others to reproduce all or pari of the copyrighted paper. 
WSRC-TR-98-00459

\title{
Computational Analysis of the
}

\section{SRS Phase III Salt Disposition Alternatives}

\author{
by \\ Richard A. Dimenna \\ Michael V. Gregory \\ Thong Hang \\ Pran K. Paul \\ Frank G. Smith, III \\ Glenn A. Taylor
}

February 1999

\footnotetext{
Westinghouse Savannah River Company Savannah River Technology Center

Aiken, SC 29808

Prepared for the U.S. Department of Energy

Under Contract DE-AC09-96SR18500
} 


\section{DISCLAIMER}

This report was prepared as an account of work sponsored by an agency of the United States Government. Neither the United States Government nor any agency thereof, nor any of their employees, makes any warranty, express or implied, or assumes any legal liability or responsibility for the accuracy, completeness, or usefulness of any information, apparatus, product, or process disclosed, or represents that its use would not infringe privately owned rights. Reference herein to any specific commercial product, process, or service by trade name, trademark, manufacturer, or otherwise does not necessarily constitute or imply its endorsement, recommendation, or favoring by the United States Government or any agency thereof. The views and opinions of authors expressed herein do not necessarily state or reflect those of the United States Government or any agency thereof.

This report has been reproduced directly from the best available copy.

Available to DOE and DOE contractors from the Office of Scientific and Technical Information, P.O. Box 62, Oak Ridge, TN 37831; prices available from (615) 576-8401.

Available to the public from the National Technical Information Service, U.S. Department of Commerce; 5285 Port Royal Road, Springfield, VA 22161. 


\section{DISCLAIMER}

Portions of this document may be illegible in electronic image products. Images are produced from the best available original document. 


\title{
Computational Analysis of the \\ SRS Phase III Salt Disposition Alternatives
}

\author{
Richard A. Dimenna \\ Michael V. Gregory \\ Thong Hang \\ Pran K. Paul \\ Frank G. Smith, III \\ Glenn A. Taylor
}

\section{Authors:

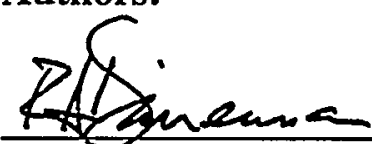

R. A. Dimenna, Engineering Modeling and Simulation

M.V. Hregon

M. V. Gregory, Engineeting Development

Mhry Hen

T. Hang, Waste Disposat \& Environmental Development

Ran 1 Pane?

P. K. Paul, Engineering Modeling and Simulation

7.N. Amethers

F. G. Smith, III, Process Chemistry and Control

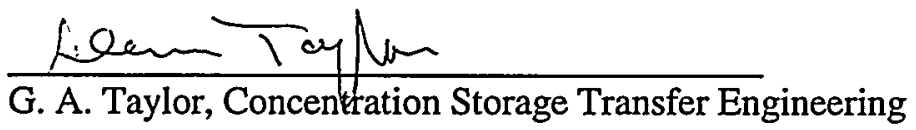

Approvals:

Saul 1 isutans

P. L. Rutland, Technical Reviewer

the

7. T. Carter HLW, Customer Review

Detuldive Sinth

C. P. Holding-Smith, Ianager, EM\&S

M. Q. Qfora

M. A Ebra, Manager, Engineering Development
Date: $2 / 17 / 99$

Date: $2 / 17 / 99$

Date: $2 / 17 / 99$

Date: $2 / 17 / 99$

Date: $2 / 17 / 99$

Date: $2 / 23 / 99$
Date: $2 / 24 / 99$

Date: $3 / 1 / 57$

Date: $3 / 2 / 99$

Date: $3 / 16 / 99$ 


\title{
Computational Analysis of the \\ SRS Phase III Salt Disposition Alternatives
}

\begin{abstract}
Completion of the Phase III evaluation and comparison of salt disposition alternatives was supported with enhanced computer models and analysis for each case on the "short list" of four options. SPEEDUPTM models and special purpose models describing mass and energy balances and flow rates were developed and used to predict performance and production characteristics for each of the options. Results from the computational analysis were a key part of the input used to select a primary and an alternate salt disposition alternative.
\end{abstract}




\section{CONTENTS}

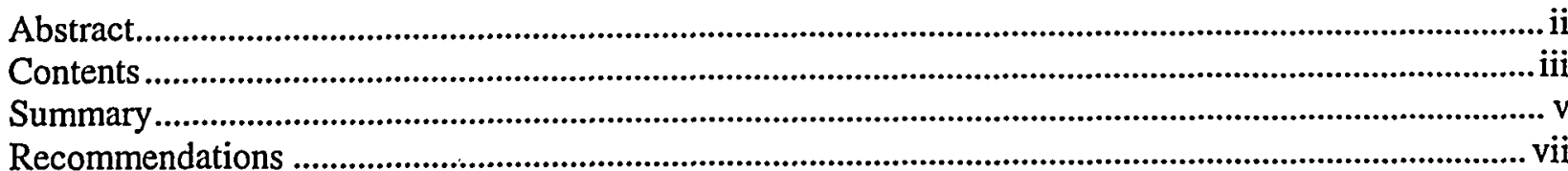

1. Introduction .......................................................................................................................................

2. General Model Considerations - Overall Analysis Approach................................................................ 4

2.1 Modeling Philosophy ..................................................................................................................... 4

2.2 Model Structure .................................................................................................................................. 6

3. Special Process Models ....................................................................................................................... 8

3.1 Tank Farm Blending Model .......................................................................................................... 8

3.1.1 Motivation ................................................................................................................................. 8

3.1.2 Model Implementation.................................................................................................................... 8

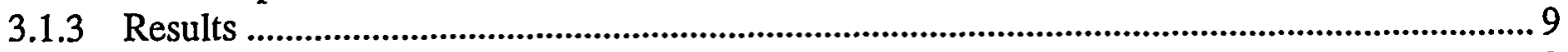

3.1.3.1 TFARM Applications ...................................................................................................

3.1.3.2 TFARM Verification ...................................................................................................

3.2 Alpha Sorption Tank................................................................................................................... 11

3.3 Defense Waste Processing Facility ................................................................................................ 12

3.3.1 DWPF Model................................................................................................................. 12

3.3.2 DWPF Salt Processing Cell Bases......................................................................................... 12

3.3.3 DWPF Chemical Cell Bases.................................................................................................. 13

3.3.4 Bases for RCT Operation..................................................................................................... 13

3.3.5 Melter Vitrification Reactions ................................................................................................ 14

3.3.6 DWPF Glass Property Bases ................................................................................................... 14

3.3.7 Chemical Components in DWPF Model .............................................................................. 15

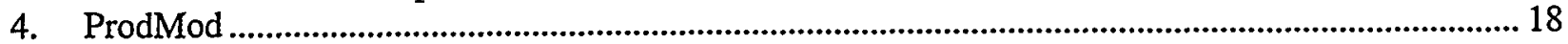

4.1 Overview of ProdMod ......................................................................................................................... 18

4.2 ProdMod Modifications.................................................................................................................... 19

4.3 Modeling and Evaluation................................................................................................................ 19

4.3.1 Feasibility Study ..................................................................................................................... 20

4.3.2 Small Tank TPB Precipitation ......................................................................................... 21

4.3.3 Caustic Side Solvent Extraction ........................................................................................ 21

4.3.4 CST Ion Exchange - DWPF Vitrification ............................................................................... 22

4.3.5 Direct Disposal in Grout..................................................................................................... 22

5. Small Tank TPB Precipitation Alternative ………………...............................................................2

5.1 Simulation of Small Tank TPB Precipitation .............................................................................. 23

5.2 Analysis of Small Tank TPB Alternative ..................................................................................... 25

5.2.1 Analysis Description............................................................................................................ 25

5.2.2 DWPF Model Results for Small Tank ITP Process.................................................................... 27

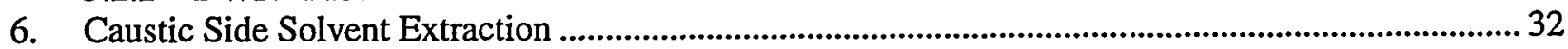

6.1 Solvent Extraction Material Balance Model..................................................................................... 32

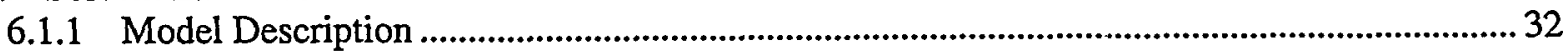

6.1.2 Comparison to TRUEX Literature Calculation ..........................................................................32

6.2 Solvent Extraction Model Results for FY 2012 Salt Blend .............................................................. 36

6.3 DWPF Model Results for Solvent Extraction Process .................................................................... 40

7. CST Non-Elutable Ion Exchange ............................................................................................................ 45

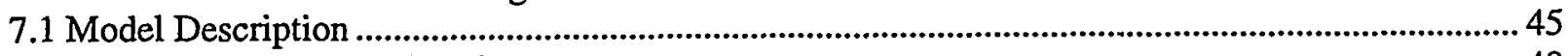

7.2 CST IX SPEEDUP Flowsheet ......................................................................................................... 48

7.3 Case Analyses ............................................................................................................................. 49 


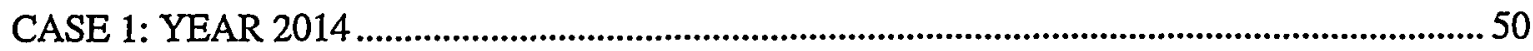

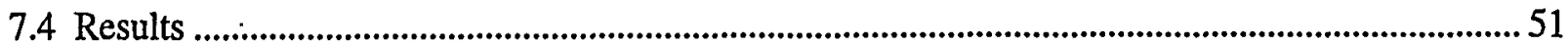

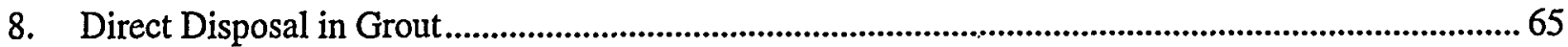

8.1 Direct Disposal in Grout Material Balance Model Description....................................................6 65

8.2 Direct Disposal in Grout Model Results for FY 2010 Salt Blend ..............................................6 65

8.3 DWPF Model Results for Direct Disposal in Grout Process ......................................................... 70

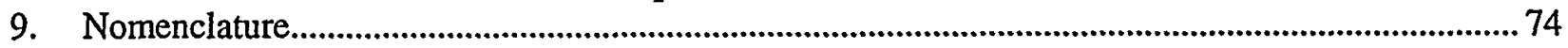

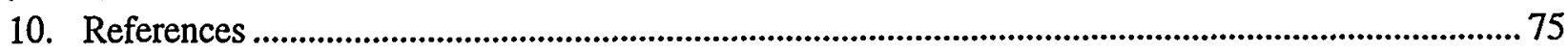

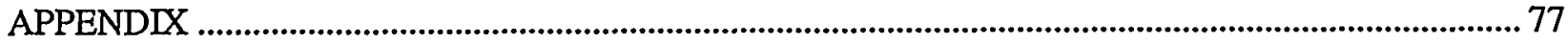




\section{SUMMARY}

In late 1997, the In Tank Precipitation facility was shut down and a process of evaluating alternative methods to process the liquid high level waste stored in the Savannah River Site High Level Waste storage tanks was begun. The purpose of evaluating alternatives to the ITP process was to determine whether another process might avoid the operational difficulties encountered. with ITP for a lower cost than that associated with modifying the ITP plant. The analysis described in this report was part of a structured approach to evaluating the proposals on a common basis to determine the most attractive.

The original SRS solicitation for salt disposition alternatives resulted in more than a hundred suggestions. The first paring of the list of alternatives was accomplished by a qualitative assessment of each of the alternatives by a design team made up of site management and technical professionals. This first reduction was referred to as Phase $\mathrm{I}$, and it resulted in a list of eighteen salt disposition alternatives which would be subjected to a more detailed quantitative analysis addressing technical feasibility, perceived risk, and estimated cost. The Phase II analysis looked at each of the eighteen alternatives as well as a base case which was the existing ITP process. The Phase III evaluation of salt disposition alternatives addressed the four alternatives on the "short list" resulting from the Phase II analysis: Small Tank TPB Precipitation, Caustic Side Solvent Extraction, CST Non-Elutable Ion Exchange, and Direct Disposal in Grout. Models used to address these options in the Phase II analysis were erlhanced to include more operational details for the Phase III analysis.

ProdMod

ProdMod was used to analyze flow streams for the entire life cycle of the HLW complex for each of the four salt disposition options. The assumptions and bases used in evaluating these options were developed from the "Bases" document to ensure consistency with the more detailed analyses of each of the specific options. The function of ProdMod was to develop a recipe for emptying the waste storage tanks and processing the contents while meeting the operating constraints and regulatory commitments for each alternative. The recipe included operating all the evaporators in a concentrated supernate (instead of salt) receiving mode in the drop tank, evaporating backlog unconcentrated wastes, intertank transfers, storing wastes in some old style tanks, etc. ProdMod results were used both for system planning purposes and as independent calculations against which the detailed analyses could be compared.

Blending model In order to provide a general capability to generate time-dependent salt blend compositions, a dynamic SPEEDUP ${ }^{\mathrm{TM}}$ model called TFARM was created. Its input was an initial state for each waste storage tank, specified for supernate, salt cake, and sludge regions as appropriate, all extracted from the standard HLW tank farm database. A blending schedule derived from ProdMod System Plan-like analyses was also required. The dynamic unit operation models in TFARM were all variants of the same basic equation set applied to each tank being represented: ordinary differential equations which track mass, mass fractions (for 34 constituents), and volume: changes. Distinct sets of equations were maintained for the supernate, salt cake, and sludge regions within each tank as needed.

DWPF A DWPF model similar to that used for the same option in Phase II was used for each of the four options. With the exception of the small tank precipitation option, the treated waste streams were fed directly to the SRAT. These streams included the salt stream from the salt processing alternative as well as an additional stream carrying actinides removed from the salt stream prior to cesium removal processing. The precipitation option included a moclel of the salt cell in the DWPF model, but the rest of the DWPF model was the same as the other options. Principal outputs from the DWPF model were the glass canister production rate, the cycle time of the SRAT and SME processes, workoff rates for the sludge and salt inventories, and recycle water volume. All results were transmitted to the Definition Team for inclusion in the summary reports. 
Non-elutable Ion exchange A one-dimensional ion exchange model was developed with SPEEDUP based on a text book example of the process. The model included a single valued mass transfer coefficient estimated from experimental data, as well as an ion exchange isotherm as a function of cesium concentration on the ion exchange resin. Calculations of axial nodalization sensitivity were completed to ensure spatial convergence. The results showed excellent comparisons with an independent model used by the Definition Group. The calculated "breakthrough" response for the column was qualitatively correct within the limitations of the physical parameters used to drive the model. The proposed operation of three CST ion exchange columns in series was modeled accurately, including the changeover at the end of each cycle when the first column reached the prescribed breakthrough conditions. Calculated results were based on conditions when a steady cyclic condition was achieved for the three columns.

Solvent extraction The SPEEDUP model for the solvent extraction process was completed and benchmarked against data. Calculations with the SPEEDUP model for the TRUEX process using the parameters reported in a paper by Leonard and Regalbuto (1994) compared well to literature values reported in the referenced paper using the SASSE model. The validated model was applied to the solvent extraction cases identified by the Definition Team. Results included output streams sent to both Saltstone and DWPF for further processing.

Small tank TPB precipitation The SPEEDUP representation of the Small Tank TPB Precipitation alternative was a comprehensive dynamic model of the overall process. It was composed of variants of pre-existing models originally developed for the High Level Waste Integrated Flowsheet Model (HLWIFM). Thus precipitation kinetics, filtration, solubility, evaporation, decomposition, absorption, and dissolution were treated in full dynamic detail as part of the mass balance with over 34 distinct chemical species. The basic building block of the models was the original HLWIFM Tank 48 model, with modifications to suit the new small tank design. The main extension to the original Tank 48 model was the addition of the dynamic equations to calculate benzene generation due to soluble NaTPB decomposition in the presence of copper or palladium catalyst.

Direct Disposal in Grout A one-dimensional thermal saltstone model was developed and enhanced by M. A. Shadday to determine the effect of Cs-137 activity on the temperature response of the grout. Results indicated that for anticipated cesium loading in the grout, the radioactive energy source term was a small but noticeable addition to the energy of hydration released during the curing process. Calculations showed acceptable temperatures at pour rates high enough to satisfy estimated operational requirements. DWPF and Saltstone calculations were also made for this case to show material balances around the processes. 


\section{RECOMMENDATIONS}

The models developed for the Phase III analysis of Salt Disposition Alternatives are a carefully constructed representation of the major individual facilities within the overall high level waste processing system. They describe mass balances for a large number of chemical species in enough detail to form an overall picture of system performance, but they are not sufficiently detailed to satisfy the needs of the next step, conceptual design. A number of model additions or enhancements are needed to address the more detailed issues associated with designing the salt processing facility.

The models were developed within the SPEEDUP environment, a choice which has proven to be valuable and which will continue to be so during the conceptual design phase. The structure of SPEEDUP allows development of fairly simple models such as mass balances in the initial phase of a project and later addition of more complexity with no penalty in either model or development efficiency. Therefore, additional relationships such as energy balances, additional chemical reactions, or more chemical species can be included in the existing models with no rework of the current models. The following is a list of model additions considered to be important for the conceptual design phase of the analysis. Further recommendations will likely be identified as the models are developed.

1. Couple the individual facility models together computationally, so that the impact of changes in one facility are evident in the overall plant response.

2. Identify the necessary chemical species that must be tracked within the model. This should include those that are already modeled, as well as those might have been omitted from the early analysis for time or computational performance considerations.

3. Develop and institute a configuration control structure for cataloging changes to the overall model.

4. Identify those facilities in which temperature dependence is important. Develop and implement the necessary energy equations.

5. Develop a more efficient comptational structure to allow the additional detail recommended here to be included without degrading the calculational performance of the model. This structure should take advantage of parallel computing capabilities to emulate actual high level waste system operations. 


\section{Computational Analysis of the \\ SRS Phase III Salt Disposition Alternatives}

\section{INTRODUCTION}

In late 1997, the In Tank Precipitation facility was shut down and a process of evaluating alternative methods to process the liquid high level waste stored in the Savannah River Site High Level Waste storage tanks was begun. The purpose of evaluating alternatives to the ITP process was to determine whether another process might avoid the operational difficulties encountered with ITP for a lower cost than that associated with modifying the ITP plant. In an effort to ensure that no candidate processes were overlooked, SRS published a request for recommended alternatives and received a large number of proposals from a wide spectrum of contributors. The analysis described in this report was part of a structured approach to evaluating the proposals on a common basis to deternine the most attractive.

The original SRS solicitation for salt disposition alternatives resulted in more than a hundred suggestions. The first paring of the list of alternatives was accomplished by a qualitative assessment of each of the alternatives by a design team made up of site management and technical professionals. This first reduction was referred to as Phase $I$, and it resulted in a list of eighteen salt disposition alternatives which would be subjected to a more detailed quantitative analysis addressing technical feasibility, perceived risk, and estimated cost. The Phase II analysis looked at each of the eighteen alternatives as well as a base case which was the existing ITP process. A key part of the Phase II analysis was a flowsheet model for each alternative which calculated the rate at which the liquid waste, or salt, could be processed and converted into a stable form for permanent storage. The result of the Phase $\Pi$ analysis was a reduction from eighteen alternatives to a short list of four. Phase III was the analysis of the four remaining alternatives.

The analytical models used for the Phase III analysis were modifications of those used for the Phase II analysis. Changes included more physical detail in the models themselves, as well as a better representation of the feed streams to the various options. The result was a better assessment of the performance of each option under the most limiting conditions it was likely to experience during the lifetime of the plant. As with the Phase II analysis, a workoff rate for salt and a production rate for the final waste form were determined for each of the four options.

The analysis effort used a team approach to address the various options. A definition team made up of engineering personnel familiar with the various processes was formed to describe the details of each of the proposed processes. For Phase II, the definition team developed a process flowsheet for each of the eighteen options and the base case. A significant part of the flowsheet development was to write the governing equations for each process step in the flowsheet so that the modeling team could write a computational model to evaluate the performance of that option. The modeling team was made up of engineers familiar with both chemical process modeling and SPEEDUPTM,"1.1 a dynamic equation solving package specifically designed for chemical process applications. The goal of the definition team was to write governing equations which approximated the perceived chemical process with enough simplicity to be evaluated quickly, but enough accuracy to give a good basis for evaluating the option. Frequent interactions between the definition and modeling teams were needed to accomplish this goal.

Another function of the definition team was to define the output required to evaluate the various options. The modeling team then formulated the output of the computational models to match the requirements of

" SPEEDUP is a trademark of Aspen Technology, Inc., Cambridge, Massachusetts. 
the definition team. Because of the batch nature of most of the processes, an averaging technique was needed to cast results in terms of yearly production rates. Because of the exceptionally tight schedule on which the options were to be defined, modeled, evaluated, and reported, the definition team played an additional role as reviewers of the calculated results from the modeling team. After several iterations for each option, the final results were assimilated by the definition team and cast into a common form for input to the design team. Meanwhile, the modeling team prepared archive documentation and computer files to preserve the work

The result of the Phase II analysis was a reduction in the list of options from eighteen to four. Phase III was the evaluation of the four options. Its purpose was to reduce the list still further, from four options to two, a preferred option and a backup, both of which will be evaluated in detail for specific design, operation, and risk issues.

The focus of this report is the Phase III analysis. It was similar to the Phase II analysis in that the models employed to evaluate the four options came from those used for the Phase II work. They were modified to some extent to address a few more details, but the general structure was the same. In addition, the relationship and interactions between the definition and modeling teams was the same as described above for Phase II.

The four options evaluated in Phase III were, in addition to the base case:

1. Small Tank TPB Precipitation

2. Caustic Side Solvent Extraction

3. CST Non-Elutable Ion Exchange - DWPF

4. Direct Disposal in Grout

Each of these options was evaluated under a common set of conditions which included:

1. Use of a common input vector structure to define the input stream from the salt tanks.

2. Separation of actinide components from the salt stream.

3. Definition of a common sludge input stream.

4. With the exception of option 4, Direct Disposal in Grout, discharge of the high activity salt output stream to the DWPF model. The DWPF model was fundamentally the same for all four options, except for the inclusion of the salt cell in the precipitation option.

5. Definition of a common output format and content.

The input salt stream for each option in Phase III was based on a blending schedule prescribed by the definition team. Input from the Tank Farm was used to drive a blending model which combined the various salt compositions from the waste tanks and produced a time dependent salt input vector. Each option was then evaluated with the most limiting conditions for the salt input: stream over the lifetime of the facility. On the other hand, the sludge input stream was treated as it was in Phase II; i.e., a 20-year average sludge composition representative of the integrated sludge flow to the DWPF over that time period.

ProdMod based HLW complex wide flow streams for the entire life cycle were analyzed for the four different salt disposition options. The assumptions and bases used in evaluating these options were developed from the "Bases" document ${ }^{1.1,1.2}$ to ensure consistency with the more detailed analyses of each of the specific options. The procedure, or recipe, for a successful operation while meeting the operating constraints and regulatory commitments for each alternative was generated by ProdMod. The recipe included operating all the evaporators in a concentrated supernate (instead of salt) receiving mode in the drop tank, evaporating backlog unconcentrated wastes, intertank transfers, storing wastes in some old 
style tanks, etc. ProdMod results were used both for system planning purposes and as independent calculations against which the detailed analyses could be compared. 


\section{GENERAL MODEL CONSIDERATIONS - OVERALL ANALYSIS APPROACH}

\subsection{Modeling Philosophy}

The Phase II and Phase III computational models evolved from two models that had been developed previously, the High Level Waste Integrated Flowsheet Model, ${ }^{2.1}$ and a detailed DWPF model developed by Smith. ${ }^{2.2}$ The IFM was used as a template for the salt processing models, in particular the precipitation option and the salt blending. The modularity of the SPEEDUP model made the task of removing the existing ITP model and replacing it with a modified precipitation model straightforward. In addition, the control logic built into the external data interface routines within the IFM SPEEDUP model were more or less applicable to the revised option of small tanks precipitation.

The actual process of separating the ITP modules from the rest of the IFM was made significantly faster because of work accomplished during 1998 on the Savannah River Technology Center Strategic Research and Development project for "Parallel Computing Acceleration of the High .Level Waste Integrated Flowsheet Model."2.3, 2.4 The initial work for that task was to separate one of the most time consuming portions of the IFM, the ITP module, to prepare the model for implementation on parallel processors. Because of this work, the remaining portion of the IFM had already been modified to run by itself. This made the task of developing a replacement salt processing model and coupling it with the rest of the HLW model significantly easier.

The IFM was a complete system model, but some parts of the model enjoyed a greater level of detail than others. One part that was particularly simple was the DWPF module. It was developed as an algebraic representation of a CPES calculation for a particular set of operating conditions. While this simple model was an acceptable approximation for the original IFM, it did not have enough flexibility to be useful for evaluating DWPF production with the various salt alternatives. A better model for this purpose was Smith's detailed DWPF model, ${ }^{2.2}$ which was used in a simplified version for the Phase II analyses.

The SPEEDUP models used for both the Phase II and Phase III analyses were fundamentally mass balances. The energy equation was not modeled explicitly in any of the modules comprising the overall model, although some of the DWPF modules incorporated a fixed evaporation rate to estimate cycle times affected by excess water inventory. Because Smith's DWPF model includecl detailed energy relationships in several of the DWPF modules, it was necessary to simplify the model to a mass balance only, thereby improving the run time performance of the model. In addition, feedback loops were removed from the entire model, both DWPF and the salt alternative models. This was to prevent convergence problems from impacting problem initialization and running time. While SPEEDUP has the ability to calculate flowsheets with feedback loops, and frequently does so with no difficulty, we felt the models would be faster to develop and more robust in running various cases with the feedback. loops removed. The use of this mathematical simplification effectively introduced a physical assumption that the feedback loops would not significantly alter the input flow rates or compositions. This was felt to be an acceptable approximation given the relative simplicity of the rest of the model.

An additional computational simplification was agreed upon early in the task. That was to run the salt alternative model and the associated DWPF calculation separately. Once again, the reason was to improve computational performance, as well as to hasten the development of: the models. Running the models independently kept both models smaller, thereby greatly simplifying development. In addition, the difficulties associated with coupling and debugging the joined models were avoided. Given the decision to remove feedback loops from the model, running the salt option and the DWPF models separately did not represent an additional physical approximation. The salt stream resulting from the salt option model was fed to the DWPF model at the correct delivery rate and composition based on the salt 
option calculation, and the impact of DWPF recycle on the salt option input was treated externally regardless.

Several general modeling assumptions and approximations were made in addition to those described above. They included:

1. Use of a common vector structure.

The salt input vector consisted of 51 components that were agreed upon by the definition team and the modeling team. The same input vector structure was used throughout all of the salt alternative models, even in situations where most of the constituents were not present. The DWPF models also used a standard vector structure, but the DWPF model had to accommodate both sludge and salt inputs. The sludge input was unique to the DWPF model, so its definition affected only the DWPF models. A 27-component sludge vector was defined based on a CPES characterization of the average sludge composition for a 20 -year period. The inputs were modified to carry most of the sludge components in oxide form, thereby simplifying calculations in the DWPF module.

The 51-component salt vector from the salt models had to be modified to mesh with a 45component salt vector used in the DWPF model. To accomplish this, a special module was written to form the interface between the salt models and the standard DWPF models. The translator module accepted a 61-component salt input stream so as to accommodate all of the materials that were introduced by the various salt options, as well as the standard 51 components comprising the common salt vector. Each of the 61 components was broken into components included in the 45-component DWPF salt vector in such a manner that, with only a few exceptions, the mass of each element was conserved. Because the glass forming components were already carried in oxide form and no chemical reactions were modeled in the DWPF module, this approach was an acceptable approximation to a DWPF mass balance.

2. Identifying required output.

Model development was aimed directly at providing a required set of information needed to evaluate specific salt alternative processing options. Because of the very short time requirements to produce this information, the models used to calculate system performance had to be simplified to the extent that only those internal processes that affected one of the desired output parameters could be included. To accomplish this goal, the Modeling Team reçuired that the Definition Team specify the parameters needed to evaluate the options and the degree of approximation that was acceptable in determining those parameters. This resulted in such approximations as using a fixed evaporation rate to boil off water, rather than trying to calculate a temperature and vapor pressure and forming an equilibrium between the liquid and gas spaces. Once a complete set of output parameters was defined, a standard output format was agreed. upon and all results were provided to the Definition Team in this format.

An important characteristic of the DWPF model output results is that they are cast in terms of yearly averages, such as a mass flow rate of klb/yr. The processes being represented by the SPEEDUP models are generally batch processes, so an evaluation in terms of yearly flows would be affected by the batch cycles as well as any startup transients. In addition, the times associated with processes upstream in the flowsheet delay the start of the downistream processes significantly. To minimize the impact of both of these influences, a delay time of 600-900 hours was imposed on the averaging process. Integrators were written for the output parameters to be included in the averages, but the integration over time did not begin until the user specified delay 
time had expired. Then the problem was run for a sufficiently long time that each facility processed between ten and twenty batches, thereby minimizing the influence of batch-to-batch variations in the components. There were still some errors introduced by the batch processing, but they were small enough to be acceptable.

3. Defining a standard input set.

A standard input set was used to evaluate all the options in Phase II. It was based on a 20-year average for both the sludge and salt input streams and formed a common basis for all of the cases evaluated. The sludge stream was modified from that provided by a CPES calculation to accommodate the actinide removal process with monosodium titanate prior to processing the salt stream in any of the options. Adding this MST stream to the sludge vector ensured that the actinides were included in the DWPF calculation without complicating the DWPF model. During the Phase III analysis, the MST stream was separated from the sludge stream and was input to the DWPF calculation explicitly.

The sludge stream assumptions were the same for Phases II and III, but the salt stream assumptions changed. Rather than use a 20-year average for the salt: stream, the blending operation to be accomplished as the various tanks are emptied was modeled and a time dependent salt input vector was determined. The options evaluated in Phase III were then driven with a salt vector representative of limiting conditions for that particular process. The blending calculation is described in detail in Section 4.

\subsection{Model Structure}

A sketch of the overall model structure is shown in Figure 2.1. The modeling differences for the various salt alternatives were in the salt processing option and the specific DWPF modules that were needed to process the salt option effluent.

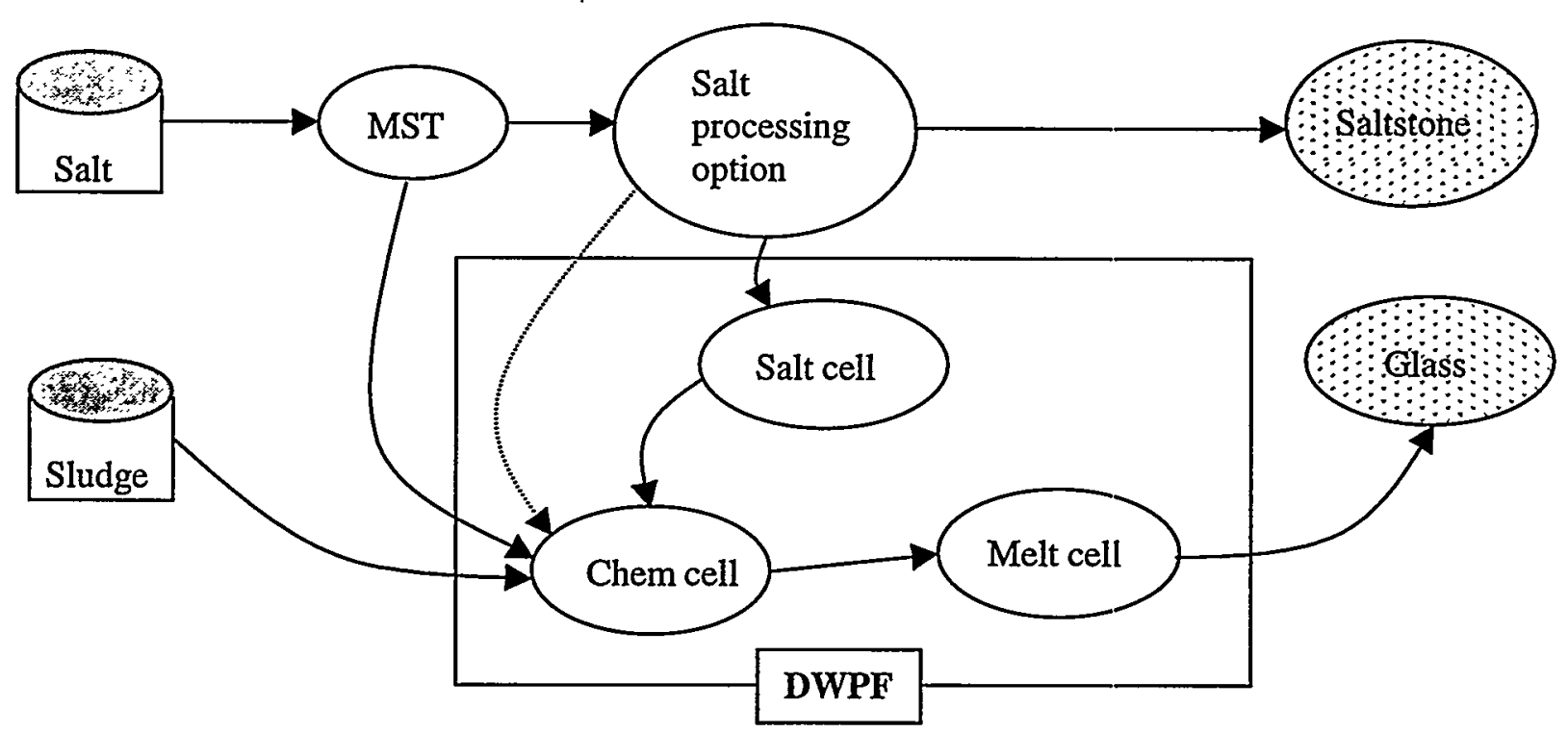

Figure 2.1 General Model Layout 
There were several salt side models and two basic DWPF side models, depending on the needs of a given option. The general salt models assessed during Phase II were:

1. Precipitation model

2. Ion exchange model

3. Solvent extraction model

4. Fractional crystallization model

5. Direct injection models, which were actually DWPF models used for these particular alternatives.

In addition, a filter model to remove actinides from the salt stream was written and employed for several of the options. This processing step took place before the salt stream was introduced to the salt processing module. As mentioned above, the computational treatment of the actinide effluent stream from this stage was different for Phases II and III, but the material was accounted for in all cases.

Most of the salt processing options required that the effluent stream carrying the cesium be sent to DWPF for vitrification. Different DWPF models were developed to account for the different nature of the incoming salt streams. The models used were:

1. Precipitation model - included the salt cell for treatment of the organic precipitate

2. Direct injection model - introduced the salt stream directly into the SRAT

Because the different salt alternatives could produce effluent streams of different compositions, a translator module was used to convert the output from the salt processing option into the common vector structure used in all of the DWPF models. This vector was different from the common vector used for the salt options. Use of the translator module avoided the need to rewrite either the salt models or the DWPF models to make their vector structures the same. 


\section{SPECIAL PROCESS MODELS}

\subsection{Tank Farm Blending Model}

\subsubsection{Motivation}

In Phase II of the Salt Disposition Alternatives study, the eighteen options being evaluated were all driven by the same 20-year average, constant salt solution feed composition, but the constant feed approximation was deemed inappropriate for the more detailed modeling of the four alternatives being considered in Phase III. Instead, the process simulation of each of the four options was designed to address the most limiting salt input conditions expected over the lifetime of the plant. This required a detailed, dynamic salt source composition unique to each option. As described in the section on ProdMod, each alternative process was evaluated based on its own operational schedule: the different start dates required unique scenarios in tank farm operations as different combinations of tanks were selected to make up the feed blend. Thus each salt disposition alternative was to have its own varying feed composition driving its simulation, with the relative fractions of the 34 chemical species of interest changing as the blends were formed.

\subsubsection{Model Implementation}

In order to provide a general capability to generate these various time-dependent blend compositions, a dynamic model called TFARM has been created with SPEEDUPTM. Its input is an initial state for each tank specifying supernate, salt cake, and sludge volumes and compositions as appropriate, all extracted from the standard HLW tank farm database..$^{3.1}$ In addition, a blending schedule derived from ProdMod System Plan-like analyses (see Section 4) is also required.

The dynamic unit operation models in TFARM are all variants of the same basic equation set applied to each tank being represented: ordinary differential equations which track mass, mass fractions (for 34 constituents), and volume changes. Distinct sets of equations are maintained for the supernate, salt cake, and sludge regions within each tank as needed. The "universal coupler" algorithm originally developed for the HLWIFM is used: a dynamic coupler model makes the necessary tank-to-tank stream connections at the appropriate times using a custom FORTRAN procedure to perform the switching logic. Also based on HLWIFM experience, pairs of step functions are used to turn on and turn off each transfer in order to ensure that the SPEEDUP dynamic timestep selection algorithm does not jurnp entirely over an event. The event times are explicitly defined in the OPERATION section via a start time and a transfer volume, thereby avoiding the computational burden of resolving dynamic discontinuities during the simulation.

The final blend preparation is carried out in a distinctive tank represented by the Mix_Tank model. In addition to the usual equation set used in the other tank unit operation models, this model also contains algebraic equations to dynamically dilute the blend to a specified $\mathrm{Na}$ molarity criterion. The Mix_Tank model can also be set up to make up annual blend batches, which was the form used for reporting the final blend data for the Phase III analyses. At the conclusion of each FY's duration, the tank's contents are automatically removed so that the next year's particular blend can be built up.

TFARM takes the schedule of events defined in the OPERATION section and, using the unit operation models, dynamically tracks the composition in all tanks as well as in the final blend tank. Supernate 
decants, direct evaporations, salt cake dissolutions, plus tank composition changes due to DWPF recycle, ESP decant, and new canyon wastes are all treated in the model. The detailed 34-species composition is tracked in each of the three regions in each tank as appropriate (i.e., those tanks that lack a particular region are represented by a unit operation model with a reduced number of equations in order to minimize the computational burden). Ultimately, the blended solution ends up in the feed tank that is the source to the salt processing alternative being simulated: its composition reflects all the operations that have occurred downstream of the blend tank. The tank volume required to store the blended salt solution was not used as a controlling parameter for the blending model. Rather, the required workoff rate for the salt solution was treated as an input parameter for the downstream calculations.

The model takes the form of approximately 10,200 differential-algebraic equations that are integrated over a time span of about 20 years. Well in excess of 100 distinct blending operations are prescribed by the input schedules over that time span. The result is a significantly compute-intensive job that requires about 25 CPU minutes per case on our fastest DEC Alpha workstation.

\subsubsection{Results}

\subsubsection{TFARM Applications}

TFARM has been used to provide detailed salt feed compositions to each of the four salt disposition alternatives currently being considered (Direct Grout, Small Tank TPB Precipitation, Solvent Extraction, and CST Ion Exchange). The model's output pinpoints in which year a blend may take on a characteristic of interest (e.g., when the blend solution has the highest alpha concentration). Then that detailed composition for that specific blend can be used to drive the salt processing alternative in order to verify that option's response to those extreme conditions. In its usual mode of use, TFARM outputs several response curves over the full lifetime of the process alternative (e.g., for $\mathrm{Na}, \mathrm{K}$, and $\mathrm{Hg}$ molarities; for $\mathrm{Ci}$ /gal and alpha activity mass fraction). Based on those observed behaviors, one or two FY blends will be used to drive the detailed process models through a significant portion of their life cycles. In addition, the full edit of the 34-constituent blend for each FY is retained for archival purposes.

\subsubsection{TFARM Verification}

The commonality between ProdMod and TFARM (they represent the outcome of operating the tank farm under the same schedule scenario) provides a useful means to cross-verify the two models. Contrasting the two models is yet another way to describe some aspects of TFARM. Though both are SPEEDUP models, they represent very different solutions of the problem of interest. Their two equation sets are fundamentally different. ProdMod consists of a set of approximately 100,000 algebraic equations which represent time advancement only implicitly in the form of the equations. TFARM consists of a set of approximately 10,000 ordinary differential equations (with only a few algebraic equations) which are dynamically integrated with an automatic timestep selector. Thus we have two essentially independent solutions of the same problem which can provide a useful verification of the two models, at least in an integral sense.

There are sufficient differences between the ProdMod and TFARM models so that one would never expect exact agreement between the two. Most of the major operations are treated by the two models: tank-to-tank supernate transfers, direct evaporation from tanks, salt cake dissolution, fresh waste sources from the canyons, DWPF recycle and ESP spent wash sources to the tank farm. But there are differences in the details of implementation. The largest difference is the neglect in TFARM of wash water from 
those tanks that are being taken out of service, which takes on significance mostly in the last years of a scenario. In addition, the recycle and spent wash sources in TFARM are kept fixed at a given composition, rather than varying as the spent wash would during sludge washing. Plus, in TFARM continued evaporation of tank contents and ETF contributions are not modeled. On the other hand, the TFARM compositions are much more detailed (tracking 34 rather than the four chemical species in ProdMod). Thus the tank composition database takes a totally different form (but hopefully consistent) between the two models. In fact, the entire reason for creating TFARM was to predict the time response of all 34 constituents in the different blends being fed to the salt disposition alternatives. The purpose of TFARM is to highlight the maximum deviations from a uniform, average composition feed, while the purpose of ProdMod is to work through the entire multi-decade production schedule with a feasible scenario which leads to clean tanks.

Though the TFARM and ProdMod results were cross-verified by more than just the one alternative, only results for the Direct Grout Option verification will be discussed here. The other cases yielded similar results. Integral results for the two models, plus results for one FY's specific blend, will be presented. The results are: the volume of salt solution blended together and the total volume of dilution water required to bring the individual blends to the $\mathrm{Na}$ molarity specification. These two volumes provide a gross, integral test of the two models in the sense that the former would identify any large discrepancies in the volume of quantities blended together (i.e., an error in the schedule details), while the latter would identify any large discrepancy in the specific compositions of the volumes taking part in the blending (i.e., an error in the tank composition data). In addition, the specific blend details for one FY (FY2006 in the first analysis of the Direct Grout Option) will be broken down into its individual sub-volumes to provide one finer-than-integral test case.

The first analysis of the Direct Grout Option was with the original schedule as defined prior to 9/21/98 (a start date of Jan 2004 rather than the Mar 2006 in the final analysis of the option). For that case, the integral comparison between TFARM and ProdMod yielded the following, where the difference is defined as (ProdMod-TFARM)/ProdMod:

Table 3.1 Integral Verification for Direct Grout Option

\begin{tabular}{|l|c|c|c|}
\hline & TFARM & ProdMod & difference \\
\hline $\begin{array}{l}\text { Total blend volume before } \\
\text { dilution }\end{array}$ & $57,569 \mathrm{kgal}$ & $58,324 \mathrm{kgal}$ & $1.3 \%$ \\
\hline $\begin{array}{l}\text { Total dilution added to get } \\
\text { to } 6 \mathrm{M} \text { Na }\end{array}$ & $20,500 \mathrm{kgal}$ & $20,397 \mathrm{kgal}$ & $-0.5 \%$ \\
\hline $\begin{array}{l}\text { Total diluted blend } \\
\text { Volume (FY2016) }\end{array}$ & $78,069 \mathrm{kgal}$ & $\begin{array}{c}79,135 \mathrm{kgal} \\
\text { (includes ETF source) }\end{array}$ & $1.3 \%$ \\
\hline
\end{tabular}

A more rigorous test is to examine the specific 'details of the blend composition for a single year rather than relying on the "macro" results provided by the integral comparisons. That has been done for the FY2006 blend for the Direct Grout Option (in the delayed start case), focusing specifically on the Na species, with the following results: 
Table 3.2 FY2006 Blend Verification for Direct Grout Option

\begin{tabular}{|c|c|c|c|}
\hline & Volume, kgal & ProdMod & TFARM \\
\hline Supernate Decants & & Na: & $7.13 \mathrm{M}$ \\
\hline Tank 43 & 362. & $5.80 \mathrm{M}$ & $7.72 \mathrm{M}$ \\
\hline Tank 26 & 400. & $9.56 \mathrm{M}$ & $9.17 \mathrm{M}$ \\
\hline Tank 30 & 300. & $10.77 \mathrm{M}$ & $7.77 \mathrm{M}$ \\
\hline Tank 47 & 149. & $8.56 \mathrm{M}$ & $8.16 \mathrm{M}$ \\
\hline Dissolved Saltcake & & Na: & $8.33 \mathrm{M}$ \\
\hline Tank 41 & 300. & $7.02 \mathrm{M}$ & $7.48 \mathrm{M}$ \\
\hline Tank 14 & 413. & $8.33 \mathrm{M}$ & $7.88 \mathrm{M}$ \\
\hline Tank 47 & 997. & $6.41 \mathrm{M}$ & \\
\hline Total Blend & 2921. & $7.66 \mathrm{M}$ & $912 . \mathrm{kgal}$ \\
\hline $\begin{array}{l}\text { Dilution H2O to achieve } \\
\text { 6 Ma Na }\end{array}$ & & $809 . \mathrm{kgal}$ & \\
\hline
\end{tabular}

The results in Table 3.2 illustrate several points of interest. First, the tank compositions differ between the two models, which may have several causes: differences in the initial tank composition database, differences in the effects of tank-to-tank transfers, modeling differences (e.g., Tank 43 is an evaporator feed tank - evaporator systems are handled very differently in the two models). Second, the differences in the supernate and saltcake regions tend in opposite directions, thus the net effect is minimized: the total blend $\mathrm{Na}$ content is roughly the same, thus the final composition of the two blends do not differ greatly. The result is that both models predict a dilution volume that agrees to within about $10 \%$. Third, the $\mathrm{Na} \mathrm{M}$ value for the total blend in both models can be almost trivially calculated by hand, and is found to be in agreement with the data produced by the models. The ultimate conclusion is that on the "micro" level as well as on the "macro" level, both models are consistent to within the uncertainty on the basic tank farm data itself (typically larger than 10\%).

\subsection{Alpha Sorption Tank}

The model feeds salt solution in $60 \mathrm{kgal}$ batches into the Alpha Sorption Tark. MST slurry (11 wt\% MST in water) is added to the tank in $1 \%$ excess over the stochiometric amount required to complex uranium, strontium and plutonium salts in the solution. Each AST batch is held for 24 hours to simulate the adsorption process. Following the hold time, the AST batch is continuously passed through a filtration step. A stream is added to the effluent from the AST to simulate water added from the ETF and water added to wash the AST. The filter is assumed to be $100 \%$ efficient in removing solids from the incoming salt solution. The solids fraction includes metal oxides, MST and MST complexes, that are carried in the salt solution. Output from the filter is separated into filtrate and solids slurry streams. Water is added to the solids stream at the specified flush ratio of 16.69 pounds of water per pound of solids. The filtrate is collected in the Salt Solution Holding Tank and from there fed continuously to the grout plant. The solids fraction is collected in the Sludge Slurry Receipt Tank. Material collected in the SSRT is added as an input stream to the SRAT in the DWPF model with the volume prorated over each SRAT batch as:

$$
V_{\text {SRAT }}=\frac{\text { SRAT Cycle Time }}{\text { SSRT Collection Time }} V_{\text {SSRT }}
$$

where $V_{S R A T}$ is the volume of slurry added to each SRAT batch. 


\subsection{Defense Waste Processing Facility}

\subsubsection{DWPF Model}

All of the salt processing options send material to the DWPF. The DWPF model ${ }^{3.1}$ consists of two major components: (1) The salt cell model shown schematically in Fig. 3.1 and (2) a combined chemical cell melt cell model shown schematically in Fig 3.2. Only the small tank TPB precipitation process uses the DWPF salt cell to hydrolyze the tetraphenyl-borate salt complexes generated by the process. As can be seen in Fig. 3.1, the salt cell process has been simplified for the purposes of this model calculation. The organic evaporator is neglected entirely since it should not be limiting to the overall processing times. It is further assumed that the salt cell is able to process two batches of precipitate during the time period of a single cycle in the SRAT and SME. That is, parameters (time delays) in the salt cell model were adjusted such that it would not limit the overall DWPF processing rate.

All four of the salt disposition options send material to the SRAT in the DWPF chemical cell. For the Direct Grout option, only an MST stream from alpha decontamination operations is sent to the SRAT. For Solvent Extraction, a $0.01 \mathrm{M}$ nitric acid stream containing the extracted cesium is sent to the glass plant in addition to the MST stream. For the ion exchange option, the MST stream and the spent IX resin are processed through the SRAT. The small tank precipitation option sends the processed salt stream to the salt cell, which then results in a precipitate stream being sent to the SRA'T.

A version of the PCCS ${ }^{3.2}$ was used to determine the optimal (minimum frit) glass blend for the Direct Grout and Solvent Extraction case studies. For Small Tank TPB, the amounts of sludge, salt and frit processes through DWPF were set to predetermined ratios to ensure that the inventories of sludge and salt would be worked off at same rate. Since the ion exchange resin significantly changes the glass composition, for this option the glass blend was also fixed. All of the DWPF calculations were based on a 5000 gal sludge batch and a 100\% attainment of 425 glass canisters per year.

\subsubsection{DWPF Salt Processing Cell Bases}

The simplified reaction scheme shown below was used to model hydrolysis teactions in the salt cell. These reactions represent $84 \%$ of the proposed true reaction pathway. The rnodel does not track organic species other than benzene.

- Reactants

$\mathrm{CsB}\left(\mathrm{C}_{6} \mathrm{H}_{5}\right)_{4}+\mathrm{HCOOH}+3 \mathrm{H}_{2} \mathrm{O}$

$\mathrm{KB}\left(\mathrm{C}_{6} \mathrm{H}_{5}\right)_{4}+\mathrm{HCOOH}+3 \mathrm{H}_{2} \mathrm{O}$

$\mathrm{NaB}\left(\mathrm{C}_{6} \mathrm{H}_{5}\right)_{4}+\mathrm{HCOOH}+3 \mathrm{H}_{2} \mathrm{O}$

$\mathrm{NH}_{4} \mathrm{~B}\left(\mathrm{C}_{6} \mathrm{H}_{5}\right)_{4}+\mathrm{HCOOH}+3 \mathrm{H}_{2} \mathrm{O}$
Products

$\mathrm{CsCOOH}+\mathrm{B}(\mathrm{OH})_{3}+4 \mathrm{C}_{6} \mathrm{H}_{6}$

$\mathrm{KCOOH}+\mathrm{B}(\mathrm{OH})_{3}+4 \mathrm{C}_{6} \mathrm{H}_{6}$

$\mathrm{NaCOOH}+\mathrm{B}(\mathrm{OH})_{3}+4 \mathrm{C}_{6} \mathrm{H}_{6}$

$\mathrm{NH}_{4} \mathrm{COOH}+\mathrm{B}(\mathrm{OH})_{3}+4 \mathrm{C}_{6} \mathrm{H}_{6}$

Fixed volumes of formic acid and copper catalyst were added to each PR batch: 
1. 167 gallons of $90 \mathrm{wt} \%$ formic acid, and

255 gallons of $5 \mathrm{wt} \%$ copper nitrate.

Time delays were used in the model to match the nominal salt cell operating time. Two salt cell batches were run for every chemical cell batch processed. The $O E$ was not modeled since benzene separation was essentially complete in the PR boiling. Since the model does not include an energy balance, temperature is immaterial to the model calculations, although a built in temperature profile is used to simulate actual operating conditions.

\subsubsection{DWPF Chemical Cell Bases}

Acid additions to the SRAT and SME used fixed volumes representative of plant operating practice. For each SRAT batch the model added:

1. 200 gallons of $50 \mathrm{wt} \%$ nitric acid, and

2. 150 gallons of $90 \mathrm{wt} \%$ formic acid.

If some nitric acid enters the SRAT through the salt feed stream (as was the case in some of the alternative salt processing schemes) the 200 gallon volume was reduced by the equivalent acid added with the input stream.

In each SME batch the model added 100 gallons of $90 \mathrm{wt} \%$ formic acid. The F-N redox value in the SME was calculated using the experimentally based equation,

$$
\mathrm{F}-\mathrm{N}=0.227 * \text { (liquid density }) *(0.646 *[\text { Formate }]-1.403 *[\text { Nitrate }])
$$

Some formic acid will be removed in the SRAT cycle during the evaporation. The amount of acid lost is calculated by an ideal solution estimate of the vapor composition and may not be the nominal $40 \%$.

Mercury is removed from the solution in the SRAT and collected as a side stream. To simplify the number of chemical species that must be tracked, mercury is left as $\mathrm{HgO}$ throughout the process.

\subsubsection{Bases for RCT Operation}

Caustic and inhibitor are added to the RCT to produce a recycle solution having the following composition:

\section{$0.5 \mathrm{M} \mathrm{NaOH}$ and $0.045 \mathrm{M} \mathrm{NaNO}_{2}$}

Water evaporated in the SRAT, SME and melter goes directly to the RCT in our simplified model. In addition, water is added to the RCT at the continuous rate of $4.05 \mathrm{gpm}$ to account for miscellaneous water additions from the SAS stream, film cooler, equipment decontamination, and laboratory flushes. 


\subsubsection{Melter Vitrification Reactions}

The following simplified oxidation reactions were used to convert metal salts and other compounds into oxides in the glass melter:

$\begin{array}{ll}\underline{\text { Reactants }} & \text { Products } \\ 2 \mathrm{~B}(\mathrm{OH})_{3} & \mathrm{~B}_{2} \mathrm{O}_{3}+3 \mathrm{H}_{2} \mathrm{O} \\ 2 \mathrm{C}_{6} \mathrm{H}_{6}+15 \mathrm{O}_{2} & 12 \mathrm{CO}_{2}+6 \mathrm{H}_{2} \mathrm{O} \\ 2 \mathrm{CsCOOH}+\mathrm{O}_{2} & \mathrm{Cs}_{2} \mathrm{O}+2 \mathrm{CO}_{2}+\mathrm{H}_{2} \mathrm{O} \\ 2 \mathrm{KCOOH}+\mathrm{O}_{2} & \mathrm{~K}_{2} \mathrm{O}+2 \mathrm{CO}_{2}+\mathrm{H}_{2} \mathrm{O} \\ 2 \mathrm{NaCOOH}+\mathrm{O}_{2} & \mathrm{Na}_{2} \mathrm{O}+2 \mathrm{CO}_{2}+\mathrm{H}_{2} \mathrm{O} \\ 2 \mathrm{NH}_{4} \mathrm{COOH}+\mathrm{O}_{2} & 2 \mathrm{NH}_{3}+2 \mathrm{CO}_{2}+2 \mathrm{H}_{2} \mathrm{O} \\ 2 \mathrm{Cu}\left(\mathrm{NO}_{3}\right)_{2} & 2 \mathrm{CuO}_{2}+4 \mathrm{NO}_{2}+\mathrm{O}_{2} \\ 4 \mathrm{HNO}_{3} & 4 \mathrm{NO}_{2}+2 \mathrm{H}_{2} \mathrm{O}+\mathrm{O}_{2} \\ 2 \mathrm{HCOOH}^{2}+\mathrm{O}_{2} & 2 \mathrm{CO}_{2}+2 \mathrm{H}_{2} \mathrm{O} \\ 2 \mathrm{NaOH}^{2} & \mathrm{Na}_{2} \mathrm{O}+\mathrm{H}_{2} \mathrm{O} \\ 4 \mathrm{Na} \mathrm{NO}_{3} & 2 \mathrm{Na}_{2} \mathrm{O}+4 \mathrm{NO}_{2}+\mathrm{O}_{2} \\ 4 \mathrm{NaNO}_{2}+\mathrm{O}_{2} & 2 \mathrm{Na}_{2} \mathrm{O}+4 \mathrm{NO}_{2} \\ 2 \mathrm{NaTi}_{2} \mathrm{O}_{5} \mathrm{H} & \mathrm{Na}_{2} \mathrm{O}+4 \mathrm{TiO}_{2}+\mathrm{H}_{2} \mathrm{O}\end{array}$

These reactions will closely approximate the $\mathrm{NO}_{2}$ emission but, by assuming complete oxidation, they do not account for carbon monoxide or hydrogen in the melter off-gas.

\subsubsection{DWPF Glass Property Bases}

The DWPF model uses a version of the PCCS calculation ${ }^{3.2}$ to determine the minimum amount of frit that can be added to each SME batch that will make acceptable glass meeting all property constraints including uncertainty. Glass properties are calculated using the correlations shown below. In all of the equations, the chemical species shown in square brackets represent molar concentrations of oxides in the glass.

Liquidus Temperature $\left(T_{L}\right.$ in $\left.{ }^{\circ} \mathrm{C}\right)$

$$
T_{L}=T_{0}+K_{T} \frac{a\left[\mathrm{Fe}_{2} \mathrm{O}_{3}\right]}{b\left[\mathrm{SiO}_{2}\right]+c\left[\mathrm{Al}_{2} \mathrm{O}_{3}\right]}
$$

with the constant values: 


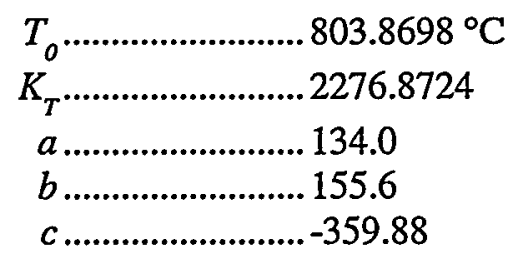

$\underline{\text { Melt Viscosity ( } \eta \text { in poise) }}$

$$
\eta=\exp \left(m-n \frac{2\left\{\left[\mathrm{Fe}_{2} \mathrm{O}_{3}\right]-\left[\mathrm{Al}_{2} \mathrm{O}_{3}\right]+\left[\mathrm{K}_{2} \mathrm{O}\right]+\left[\mathrm{Li}_{2} \mathrm{O}\right]+\left[\mathrm{Na}_{2} \mathrm{O}\right]\right\}+\left[\mathrm{B}_{2} \mathrm{O}_{3}\right]}{\left[\mathrm{SiO}_{2}\right]}\right)
$$

with the constant values:

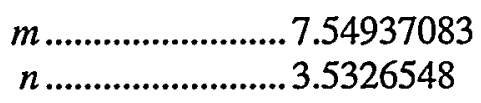

Glass Durability $(\Delta G)$

Durability can be cast into the form of limits on the glass free energy which is calculated from the relationship

$$
\Delta G=\sum_{i} \alpha_{i}\left[C_{i}\right]
$$

In Eq. (3), the $\alpha_{i}$ are free energy coefficients given in the following table.

Table 3. Free energy coefficients for oxides in DWPF model.

\begin{tabular}{|c|c|c|c|c|c|}
\hline Oxide & $\alpha_{i}$ & Oxide & $\alpha_{i}$ & Oxide & $\alpha_{i}$ \\
\hline $\mathrm{Al}_{2} \mathrm{O}_{3}$ & 37.68 & $\mathrm{Fe}_{2} \mathrm{O}_{3}$ & 14.56 & $\mathrm{SiO}_{2}$ & 4.05 \\
\hline $\mathrm{B}_{2} \mathrm{O}_{3}$ & -10.43 & $\mathrm{~K}_{2} \mathrm{O}$ & -76.41 & $\mathrm{TiO}_{2}$ & 16.27 \\
\hline $\mathrm{BaO}$ & -23.18 & $\mathrm{Li}_{2} \mathrm{O}$ & -24.04 & $\mathrm{U}_{3} \mathrm{O}_{8}$ & -23.77 \\
\hline $\mathrm{CaO}$ & -13.79 & $\mathrm{MgO}$ & -6.57 & $\mathrm{ZrO}_{2}$ & 17.49 \\
\hline $\mathrm{Cr}_{2} \mathrm{O}_{3}$ & 11.95 & $\mathrm{MnO}$ & -24.44 & $\mathrm{P}_{2} \mathrm{O}_{5}$ & -26.55 \\
\hline $\mathrm{Cs}_{2} \mathrm{O}$ & -80.38 & $\mathrm{Na} 2 \mathrm{O}$ & -53.09 & & \\
\hline $\mathrm{CuO}$ & -4.96 & $\mathrm{NiO}$ & 0.37 & & \\
\hline
\end{tabular}

\subsubsection{Chemical Components in DWPF Model}

A list of the 45 chemical species used in the DWPF model is given below: 


\begin{tabular}{|c|c|c|c|}
\hline 1. $\mathrm{H}_{2} \mathrm{O}$ & 2. $\mathrm{HCOOH}$ & 3. $\mathrm{C}_{6} \mathrm{H}_{6}$ & 4. $\mathrm{NH}_{3}$ \\
\hline 5. $\mathrm{B}(\mathrm{OH})_{3}$ & 6. $\mathrm{NaCOOH}$ & 7. $\mathrm{KCOOH}$ & 8. $\mathrm{CsCOOH}$ \\
\hline 9. $\mathrm{NH}_{4} \mathrm{COOH}$ & 10. $\mathrm{Cu}\left(\mathrm{NO}_{3}\right)_{2}$ & 11. NaTPB & 12. KTPB \\
\hline 13. CsTPB & 14. $\mathrm{NH}_{4} \mathrm{TPB}$ & 15. $\mathrm{NaNO}_{2}$ & 16. $\mathrm{NaNO}_{3}$ \\
\hline 17. $\mathrm{NaOH}$ & 18. $\mathrm{NaTi}_{2} \mathrm{O}_{5} \mathrm{H}$ & 19. $\mathrm{HNO}_{3}$ & 20. $\mathrm{Al}_{2} \mathrm{O}_{3}$ \\
\hline 21. $\mathrm{B}_{2} \mathrm{O}_{3}$ & 22. $\mathrm{BaO}$ & 23. $\mathrm{CaO}$ & 24. $\mathrm{Cr}_{2} \mathrm{O}_{3}$ \\
\hline 25. $\mathrm{Cs}_{2} \mathrm{O}$ & 26. $\mathrm{CuO}$ & 27. $\mathrm{Fe}_{2} \mathrm{O}_{3}$ & 28. $\mathrm{K}_{2} \mathrm{O}$ \\
\hline 29. $\mathrm{Li}_{2} \mathrm{O}$ & 30. $\mathrm{MgO}$ & 31. $\mathrm{MnO}$ & 32. $\mathrm{Na}_{2} \mathrm{O}$ \\
\hline 33. $\mathrm{NiO}$ & 34. $\mathrm{SiO}_{2}$ & 35. $\mathrm{TiO}_{2}$ & 36. $\mathrm{U}_{3} \mathrm{O}_{8}$ \\
\hline 37. $\mathrm{ZrO}_{2}$ & 38. $\mathrm{Ca} 3\left(\mathrm{PO}_{4}\right)_{2}$ & 39. $\mathrm{P}_{2} \mathrm{O}_{5}$ & 40. $\mathrm{NaCl}$ \\
\hline 41. $\mathrm{NaF}$ & 42. $\mathrm{Na}_{2} \mathrm{SO}_{4}$ & 43. $\mathrm{SrO}$ & 44. Alpha \\
\hline
\end{tabular}

45. $\mathrm{HgO}$

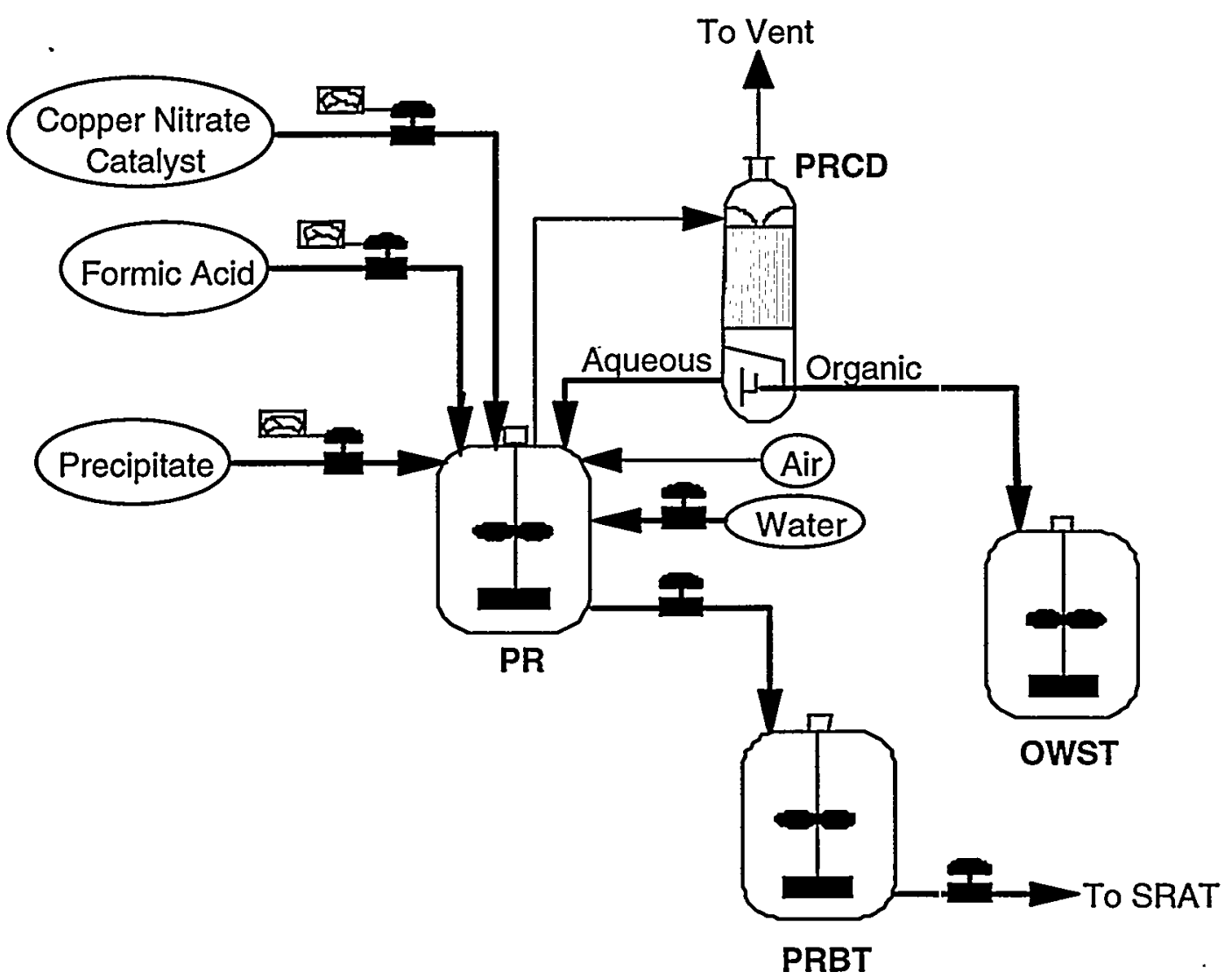

Figure 3.1 Schematic representation of DWPF Salt Cell model. 


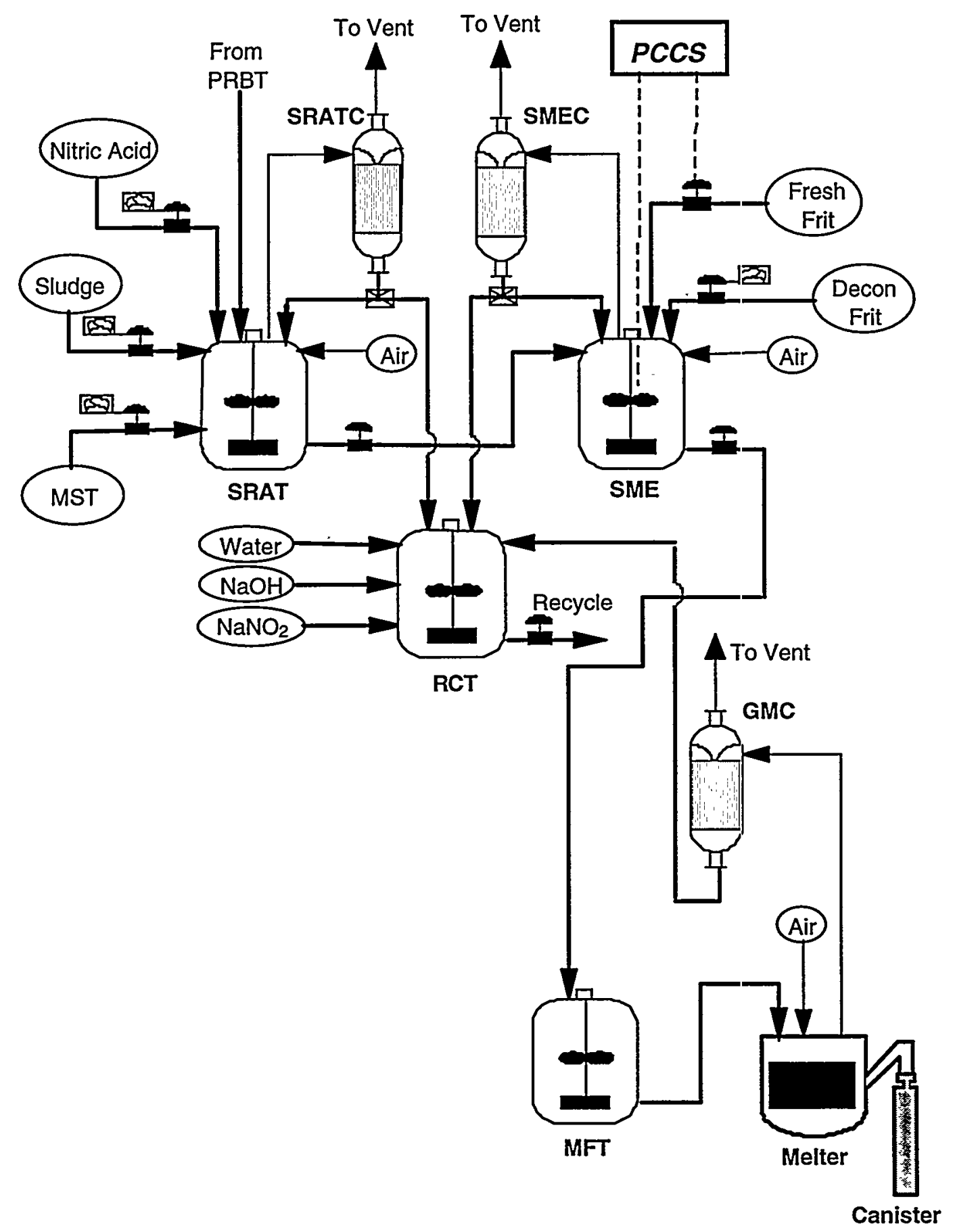

Figure 3.2 Schematic representation of DWPF Chemical and Melt Cell model. 


\section{PRODMOD}

\subsection{Overview of ProdMod}

An integrated computational tool called ProdMod ${ }^{4.1}$ was developed to simulate the waste processing behavior of the entire HLW complex at SRS for its life cycle operation. The existing ITP was modeled as the salt processing facility in ProdMod. ProdMod is a simplified integrated pseudo-dynamic simulation code based on SPEEDUP. ${ }^{1.1}$ The SRS HLW operations are modeled in ProdMod using algebraic equations only. The dynamic nature of the plant processes is modeled in linear constructs in which time dependence is implicit. ProdMod models the batch processes in event-space and the continuous processes in time-space and then couples between event-space and time-space. Figure 4.1 shows the processes and facilities along with the main flow streams modeled in ProdMod. SPEEDUP solves the process equations in ProdMod in two steps. First, the equations are blocked into independently and sequentially solvable blocks by a block decomposition method. The independently solvable linear: and nonlinear blocks are then solved using sparse linear and nonlinear solvers respectively. After successful solution, ProdMod provides HLW facility, process, and flow stream information for the entire range of simulation. The information includes tank inventory; precipitate, sludge, grout, and canister production; the salt solution blending history and their $\mathrm{Na}, \mathrm{K}$, and Cs composition; the chemical consumption in different processes; etc. ProdMod has been used to develop the HLW System Plan ${ }^{4.2}$ for the last several years.

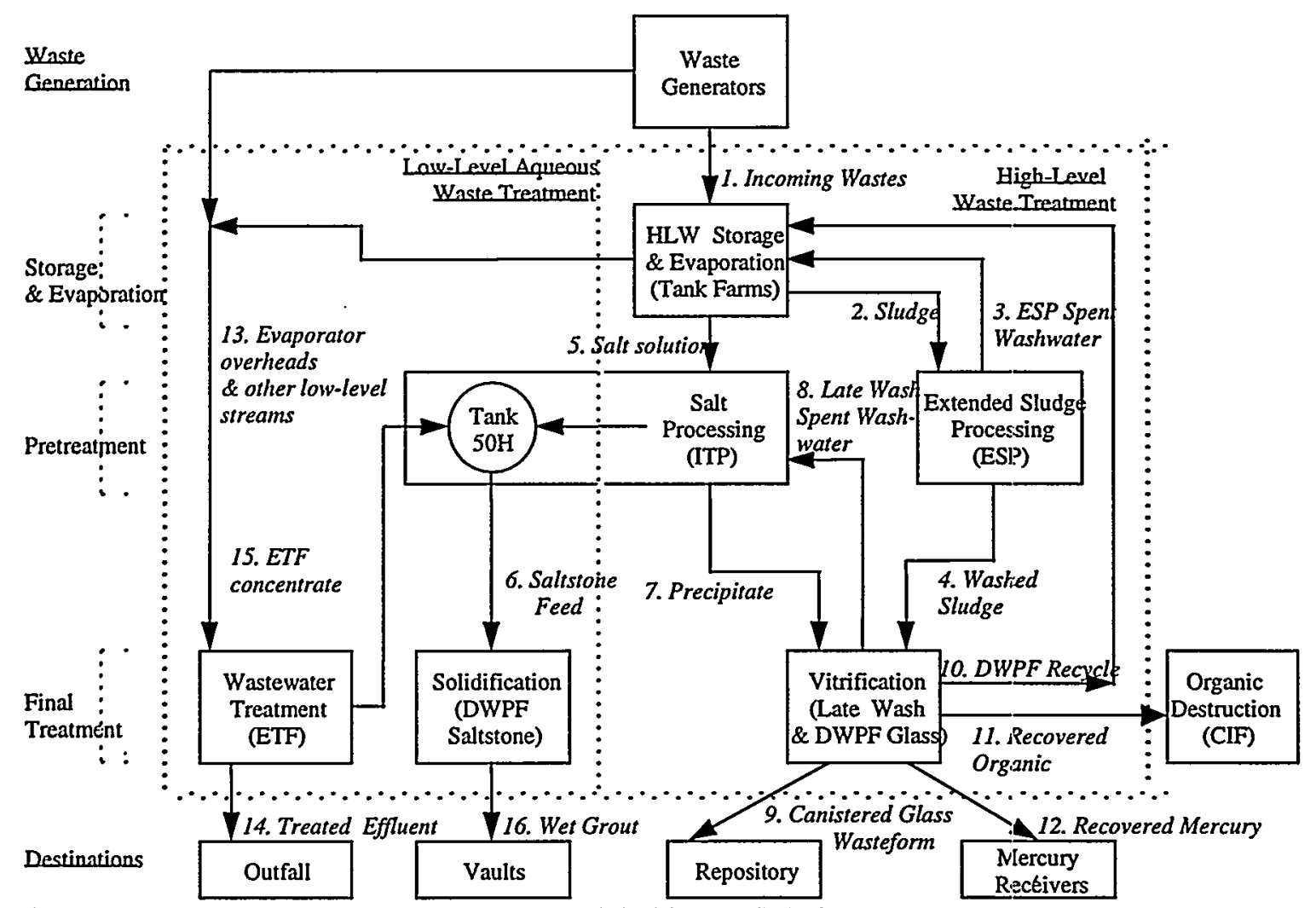

Figure 4.1 SRS HLW Process Streams Modeled in ProdMod 


\subsection{ProdMod Modifications}

ProdMod was modified to reflect a new salt disposition option and then usecl to evaluate that option for the entire life cycle to clean up all the waste tanks. In the original ProdMod, the existing ITP facility was modeled as the salt processing operation. For each of the new salt disposition options, the ITP model in ProdMod was replaced with a new proposed salt disposition operating scenario. ProdMod development is based on a flowsheeting environment that couples the waste processing processes through different incoming and outgoing flow streams. Hence, flow stream connections were also modified in ProdMod to reflect a new salt disposition option. To model and evaluate a new salt disposition option, ProdMod was modified in such a way that required minimal changes to save time and avoid bugs.

\subsection{Modeling and Evaluation}

ProdMod has been used first to evaluate whether the HLW System can successfully meet its mission objectives during the fiscal year 1998 through 2009 until a salt processing facility is available, while operating at a 200 canister/year production rate. The SRS commitment to the regulatory bodies is to produce an average of 200 canisters/year during DWPF operations. This study is termed as the Feasibility Study in this section. After completion of the feasibility study, ProdMod was used to evaluate the four salt disposition alternatives which are:

1. Direct Disposal in Grout,

2. Small Tank TPB Precipitation,

3. CST Non-Elutable Ion Exchange - DWPF Vitrification, and

4. Caustic Side Solvent Extraction.

ProdMod has used the Tank Farm waste composition and volumes per the Waste Composition System ${ }^{4.3}$ updated on August 3, 1998. In ProdMod, the ESP model has not been yet verified. As a result, the spent wash water from sludge washing and the processed sludge volumes in each sludge batch are matched to CPES results. The DWPF sludge batch composition used in all options are the same as used in HLW System Plan, Rev. 9. The spent wash water from sludge washing and the DWPF recycle are the main byproducts coming to the Tank Farm from waste processing operations. These products have a great impact on tank space in the Tank Farm due to their large volume, although these wastes are minimally contaminated and very dilute. The source of new wastes in the Tank Farm comes from F-and $\mathrm{H}$-Canyon operations. The space gain in the Tank Farm is achieved by concentrating dilute wastes in the evaporators. For tanks containing significant quantities of supernate and/or salt, the supernate and salt needs to be removed first in order to transfer sludge to ESP. Another source of new waste coming to the Tank Farm is the spent wash water after cleaning tanks for closure. In generating scenarios for life cycle operation, ProdMod modeling requires implementation of the operating constraints and regulatory commitments. The commitments are:

1. closure of non-compliant waste tanks before specified dates, and

2. maintaining an average DWPF production rate of $200 \mathrm{cans} / \mathrm{yr}$.

Some of the operating constraints are to provide:

1. minimum emergency storage space of $1,271 \mathrm{kgal}$ in each Tank Farm, and

2. minimum of $200 \mathrm{kgal}$ space in each evaporator system. 
In salt disposition option studies, ProdMod has generated salt solution blending sequence scenarios, the necessary inter-tank waste transfer, the waste processing products and byproducts, tank inventory with time, grout and canister production rate, etc., while meeting the operating constraints and regulatory commitments. The basic assumptions and bases used in the four alternatives are summarized below.

Operation Startup Date:

Direct Disposal in Grout: $\quad$ March 1, 2006

Small Tank TPB Precipitation: May 1, 2006

CST Ion Exchange: $\quad$ March 1, 2007

Caustic Side Solvent Extraction: May 1, 2007

DWPF Recycle:

Direct Disposal in Grout:

DWPF recycle production rate based on sludge only case Gillam's Memo: ${ }^{4.3}$ $\mathrm{gpm}=1.63+5.25 *$ attainment, where attainment $=1$ when DWPF operates at 500 cans/year production rate

Small Tank TPB Precipitation:

Before Small Tank TPB Startup $-\mathrm{gpm}=1.63+5.25 *$ attainment

After Small Tank TPB Startup $-320 \mathrm{kgal} /$ year plus gpm $=1.63+5.25 *$ attainment

CST Ion Exchange:

Before CST Ion Exchange Startup - gpm $=1.63+5.25 *$ attainment:

After CST Ion Exchange Startup - 1.1* CST production in kgal/klb-yr plus gpm $=1.63+5.25 *$ attainment

Caustic Side Solvent Extraction:

Before Small Tank TPB Startup - gpm $=1.63+5.25 *$ attainment

After Small Tank TPB Startup $-520 \mathrm{kgal} /$ year plus gpm $=1.63+5.25 *$ attainment

Canister Production in DWPF:

Direct Disposal in Grout:

235 cans/year

Small Tank TPB Precipitation: $\quad 210$ cans/year

CST Ion Exchange: $\quad 225$ cans/year

Caustic Side Solvent Extraction: $\quad 225$ cans/year

\subsubsection{Feasibility Study}

This study indicates that the HLW system can successfully meet its mission objectives during FY19982009 until a salt processing facility is available. This study is based on assumptions that: 
1. DWPF will produce 200 sludge only canisters per year during FY 1999 - FY 2009,

2. DWPF sludge batch composition remains the same as used in HLW System Plan, Rev. 9.,

3. RHLWE evaporator will begin radioactive operations in July 1999,

4. All three evaporators will run continuously and receive concentrated supernate instead of salt in their drop tanks,

5. Future wastes from $\mathrm{F}$ and $\mathrm{H}$ canyons are according to current published forecasts,

6. Tank 48 will continue to be a dedicated storage of benzene-bearing solution,

7. Tank 49 will return to Tank Farm waste storage service after being deinventoried to Tank 48 , and

8. Tank 50 will continue as a dedicated ETF concentrate receipt tank.

The study shows that multiple inter-area waste transfers, evaporation of dilute supernate, and storing concentrated supernate in a few old style waste tanks are needed to be in cornpliance with regulatory and safety commitments. The study identifies when and how much waste volume needs to be evaporated or transferred to which tanks. To have the required minimum space in the evaporator and Tank Farm, ProdMod has identified the need to transfer some supernate from one old style tank to another old style tank for a few cases. This study has also identified the need to operate all three evaporators in concentrate supernate instead of salt receiving mode. This feasibility study serves as the foundation for the subsequent evaluations of the four salt disposition options.

\subsubsection{Small Tank TPB Precipitation}

In modeling the Small Tank TPB precipitation option, it has been assumed that the new facility will be ready for operation in May 2006. The Tank Farm provides a blended salt solution of 5.2 million gallons at $6.44 \mathrm{M}$ Na.per year on average, which produces approximately $325 \mathrm{kgal} 10 \mathrm{wt} \%$ precipitated slurry without exceeding the Cs concentration limit of $46 \mathrm{Ci} / g a l$. The salt solution is diluted to $4.7 \mathrm{M}$ sodium in the small tank facility before adding precipitating reagents. ProdMod models the precipitate production rate based on $120 \%$ stoichiometric value of $\mathrm{K}$ and Cs present in the salt solution, along with MST adsorbents for $\mathrm{Sr}, \mathrm{Pu}$, and $\mathrm{U}$. The available spent wash water from precipitate wash is used for required dilution water. The DWPF recycle to the Tank Farm is based on a sludge-only operation algorithm ${ }^{4.3}$ before the facility start-up; after the start-up an additional $320 \mathrm{kgal} /$ year is added. ProdMod models the canisters production rate at 210 cans/year in DWPF so that sludge and precipitate finish their feeds to DWPF at the same time. Modeling results indicate that salt processing via Small Tank TPB option would complete in FY 2020, which also corresponds to the end of sludge processing.

\subsubsection{Caustic Side Solvent Extraction}

Based on the assumption that the Caustic Side Solvent Extraction facility will start up in May 2007, ProdMod models and evaluates the clean up operation using this salt disposition option. Modeling results are based on a canister production rate of 225 cans/year to finish sludge processing at the same time as salt processing. In ProdMod modeling, it is assumed that the spent MST and Solvent Extraction feeds to DWPF can be blended in with the sludge feed without increasing canister production. In this option, the Tank Farm provides a blended salt solution of 6.0 million gals at $6.44 \mathrm{M}$ Na per year on average, which does not exceed the $\mathrm{Cs}$ limit of $4.0 \mathrm{Ci} / g a l$. The DWPF recycle to the Tank Farm is based on a sludgeonly operation algorithm ${ }^{4.3}$ before the facility start-up, and after the facility has started up an additional $520 \mathrm{kgal} / \mathrm{year}$ is added. Based on ProdMod results, both salt and sludge processing would complete in DWPF in FY 2019, while producing 225 cans/year. 


\subsubsection{CST Ion Exchange - DWPF Vitrification}

ProdMod modeling for the CST Ion Exchange option is based on the facility start up date in March 2007. In this option, the Tank Farm provides a blended salt solution of 6.0 million gals at $6.44 \mathrm{M}$ Na per year on average, which does not exceed the $\mathrm{K}$ and $\mathrm{Cs}$ limits of $0.173 \mathrm{M}$ and $3.30 \mathrm{Ci} / \mathrm{gal}$ respectively. The salt solution is then diluted to $5.6 \mathrm{M} \mathrm{Na}$ in the Ion Exchange facility for feed to the Ion Exchange columns. In ProdMod, the contaminated CST production rate is calculated in three steps based on the following recipe:

$$
\begin{aligned}
& \text { Step } 1^{1.2}- \\
& \text { mg Cs } / L \Rightarrow C \text { conc of salt soln }(\mathrm{Ci} / \mathrm{gal}) * 1000 /(3.7854 * 87 * \text { frac }), \\
& \text { where, frac }=0.225
\end{aligned}
$$

Step $2^{4.4,4.5}$

$\mathrm{mg} \mathrm{Cs} / \mathrm{g} \mathrm{CST} \Rightarrow 0.90 *[7.97 * \ln (\mathrm{mg} \mathrm{Cs} / \mathrm{L})-1.61]$

Step 3 -

lbs/year CST => salt sol vol $\left(@ 5.6 \mathrm{M} \mathrm{Na}^{+}\right) * 3.7854 *(\mathrm{mg} \mathrm{Cs} / \mathrm{L}) /[(\mathrm{mg} \mathrm{Cs} / \mathrm{g} \mathrm{CST}) * 453.6]$

The DWPF recycle to the Tank Farm is based on a sludge-only operation algorithm ${ }^{4.3}$ before the facility start-up, and after the start-up an additional amount of 1.1 times the CST production in $(\mathrm{kgal} / \mathrm{klb})$ is added. Canister production at a rate of 225 cans/year is modeled in DWPF so that the radionuclides loaded MST and CST from the salt processing can be blended with the sludge at DWPF, and both sludge and salt processing can finish at the same time. It is also assumed that no additional cans will be produced as a result of the blending of CST resin with the sludge feed. The model predicts that salt processing via CST Ion Exchange along with sludge processing would complete in FY 2019.

\subsubsection{Direct Disposal in Grout}

ProdMod models the Direct Disposal in Grout option under the assumption that the new grout facility will be in operational in March 2006, and will begin processing at maximum throughput. ProdMod models that DWPF will run at a rate of 235 canisters production per year. The DWPF production rate is synchronized to the Grout Facility production rate so that both the facilities can cease their operations at the same time. As a result, all the MST, after adsorbing Sr, U, and Pu and the residual sludge solids, can be transferred periodically to the sludge feed in DWPF. The DWPF recycle to the Tank Farm is based on the sludge-only operation algorithm of Reference 4. ProdMod schedules the salt solution blending such that Tank Farm provides 6.44 million gallons of salt solution at $6.0 \mathrm{M} \mathrm{Na}$, with less than $3 \mathrm{Ci}$ /gal cesium to the proposed new Saltstone facility. Modeling results indicate that salt processing via Direct Disposal in Grout would complete in FY 2018, along with sludge only glass production completion at the same time. 


\section{SMALL TANK TPB PRECIPITATION ALTERNATIVE}

\subsection{Simulation of Small Tank TPB Precipitation}

The schematic for the Small Tank TPB Precipitation process model is shown in Fig. 5.1, where quotation marks around "Tank" indicate a modeling construct rather than an actual tank (e.g., the Accumulation "Tank" is a model construct to interface between the Precipitation and Concentration Tanks which are running as continuous processes, and the Wash Tank which is running as a batch process). The broad arrows indicate major paths entering or leaving the process, one being the specification of the salt solution feed, one sending washed precipitate to DWPF, and the third sending filtrate to Saltstone. Spent wash water is recycled to dilute the feed as needed and as available. The front-end Feed Specification is what is provided by the TFARM blending model discussed in Section 3.1.

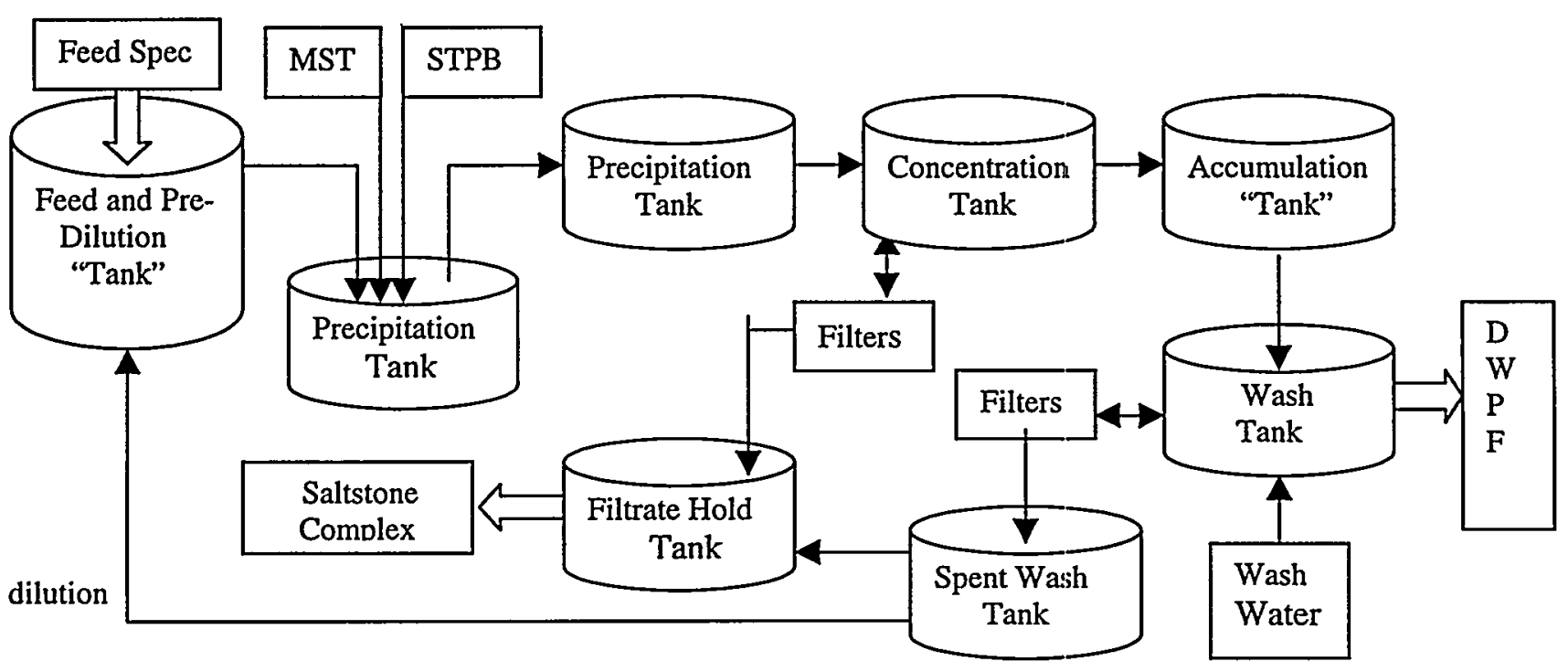

Fig. 5.1 Small Tank TPB Precipitation Process Model

The SPEEDUP representation of the Small Tank TPB Precipitation alternative is a comprehensive dynamic model of the overall process. To maximize the rate of model development, it is composed of variants of pre-existing models originally developed for the High Level Waste Integrated Flowsheet Model. Thus precipitation kinetics, filtration, solubility, evaporation, decomposition, adsorption, and dissolution are treated in full dynamic detail as part of the mass balance over 34 distinct chemical species. The basic building block of the models is the original HLWIFM Tank 48 model, with modifications to suit the new small tank design. The main extension to the original Tank 48 model is the addition of the dynamic equations to calculate benzene generation due to soluble STPB decomposition in the presence of copper or palladium catalyst.

The basic Tank 48 model integrates ordinary differential equations for the total tank slurry mass, and for each individual species making up that mass. A solids mass is calculated by summation over a subset of 
the species. Precipitation kinetics are controlled through the definition of a rate constant. STPB solubility is defined by a correlation dependent on temperature and $\mathrm{Na}$ molarity. Benzene generation due to both radiolysis and catalytic decomposition is accounted for. Two significant approximations are made: the enhanced safety case assumption that benzene is released as it is generated at a fixed rate of $10 \mathrm{mg} / \mathrm{L}-$ $\mathrm{hr}$; and slurry temperatures are fixed at $25^{\circ} \mathrm{C}$. Adsorption of Sr and U onto MST is accounted for. A filtrate flow correlation is used, based on the solids content and the number of filters on line. Each of the individual tank models is based on some variant of these details, depending on the processes required to simulate the functionality of that tank. In order to minimize the running time, unnecessary equations out of the basic model are deleted for the appropriate tank models.

A brief summary of the models making up the elements shown in Fig. 5.1 follows:

1. Accum_Tank: An artificial construct used to interface the continuous precipitation and concentration unit operations with the batch-wise precipitate washing step. This model is based on the Tank 48 model with filtration logic removed. The model accumulates concentrated product until at least the predefined batch volume is available; then it passes batches forward to be washed. That transfer is controlled by the External Data Interface which links the SPEEDUP model to custom FORTRAN that controls the batched process.

2. Collect_Tank: Used to integrate the grout volume leaving Saltstone_Complex. This model consists of simple integrations of the mass and component mass fraction equations.

3. Conc_Tank: Represents the concentration operation that follows the precipitation steps. This model is based on a variant of the Tank 48 model, running in a continuous operation mode. It holds up the slurry product from the precipitation operation until the solids weight percent criterion is met through filtration. At that point, the model starts transferring concentrated product continuously to Accum_Tank with the product flow rate determined by the difference between the feed to the tank and the filtrate flow leaving the tank.

4. Filtrate_Tank: Combines filtrate from Conc_Tank with spent wash water from Spent_Wash_Tank and passes the result onwards to Saltstone_Complex. Ordinary differential equations for the mass balance and the component mass fractions are integrated. The flow rate to Saltstone is set at the predetermined value unless the flow into the tank is less, at which point the departing flow is set to the incoming flow.

5. Precip_Tank: Represents the precipitation operations. This model accumulates slurry from either the Salt_Feed_Tank or the downstream Precip_Tank for the duration of the defined holdup interval, then it passes precipitated slurry on to either the next Precip_Tank or the Conc_Tank. The current process representation has two Precip_Tanks in series, with STPB and MST additions into the first tank only. This model is based on the Tank 48 model, running in a continuous operation mode with filtration logic removed. The holdup intervals are predefined in the input so that the IF test logic in the OPERATION section will turn on the transfer at the correct elapsed time from the start of the simulation. The second Precip_Tank does not begin to receive feed until the holdup duration in the first expires, and it does not feed the Conc_Tank until it satisfies its own post-feed holdup duration.

6. Recycler: Controls dilution water source, either provided by Spent_Wash_Tank or by a fixed source. IF test logic in the OPERATION section defines the time at which spent wash water is to be used for dilution. Prior to that time, dilution water of a prescribed composition will be supplied. The rate of dilution addition is calculated in the Salt_Feed_Tank model. 
7. Saltstone_Complex: Represents the Saltstone and grout processes, based on the same model in HILWIFM.

8. Salt_Feed_Tank: Used to provide the salt solution feed that drives the entire process. This model takes the input salt solution feed composition, the prescribed work-off rate for the salt solution, and the dilution target to dynamically calculate the dilution water flow rate required to meet the $\mathrm{Na}$ molarity specification. As spent wash starts being used for the dilution source, its composition will vary, hence the amount of dilution water added will vary in concert.

9. Spent_Wash_Tank: Used to accumulate spent wash from Wash_Tank and send it on either for use as dilution in Salt_Feed_Tank or for mixing into Filtrate_Tank. The Recycler model controls the drawoff of the spent wash for use as dilution water. IF test logic in the OPERATION section defines the time at which spent wash is to start transferring to the Filtrate_Tank, and the rate at which it transfers. This rate needs to be iteratively determined by the user so that the spent wash tank volume neither goes negative nor increases without bound.

10. Wash_Tank: Represents the batched precipitate washing process. This model is a minor variation of the original HLWIFM Tank 48 model. It is fed by the Accum_Tank with the batch steps under control of the EDI. The fixed duration of the washing step is defined within the EDI FORTRAN (e.g., 2 days). During that interval, wash water will be turned off when the wash criterion is met, and filtration will cease when the solids criterion is met. Washed precipitate is sent onward to the DWPF process which is outside the current model. The next batch to be washed will be pulled into the Wash_Tank when sufficient volume is present. If that condition is not met, the EDI will check at one day intervals until the condition is satisfied. Thus individual wash batch cycles may not be of the same duration, depending on the state of Accum_Tank. Averaging of quantities over batches needs to be done with caution to ensure that the duration is long enough to span the varying cycle lengths.

The SPEEDUP model listing is essentially self-documenting, so that detail is not repeated here.

\subsection{Analysis of Small Tank TPB Alternative}

\subsubsection{Analysis Description}

It was desired to run the Small Tank TPB Alternative with a salt stream that would test the curie concentration limits of the downstream processes. A salt stream was chosen which had the highest cesium to potassium ratio (Year 2017). This stream also had high transuranics and sludge concentrations. The high cesium to potassium ratio yielded the most concentrated cesium since there was relatively less KTPB available to dilute the CsTPB. The concentrated, washed slurry, that which was passed to DWPF, was $45.5 \mathrm{Ci} / g a l$.

Several deviations from normal operation were required because of the composition of the feed stream. The ideal concentration process is run so that the end solids concentration is $10 \mathrm{wt} \%$, which includes both xTPB, sludge, and MST compounds. The "average" flowsheet would provide about 8.5-9.0 wt\% KTPB solids to DWPF with the remaining 1-1.5 wt\% being composed of the sludge and MST. The DWPF throughput is limited by the amount of KTPB which can be processed by the Salt Cell. The feed stream used for this analysis, if concentrated to $10 \mathrm{wt} \%$ total solids, yielded about $7.7 \mathrm{wt} \% \mathrm{KTPB}$. If the process were to supply the equivalent amount of KTPB at $10 \mathrm{wt} \%$ solids as expected by the "average" flowsheet, the salt cell would be overwhelmed by the total volume of feed necessary to process the same amount of KTPB. Therefore, the analysis was performed with a total solids concentration of about $10.8 \mathrm{wt} \%$, giving 
a KTPB solids concentration of about $8.7 \mathrm{wt} \%$. By running in this manner, DWPF can process the amount of feed it receives while making the desired amount of glass.

The other major deviations from the bases given were a result of the reaction kinetics of the NaTPB with the $\mathrm{Cs}+$ and $\mathrm{K}+$ ions. The bases originally stipulated that the reaction tanks provide a 24 hour hold-up time with a 33\% excess NaTPB over the stoichiometric value. The first series of runs showed that there was insufficient hold up time and excess NaTPB to achieve the desired cesium decontamination. The hold-up time was increased to 72 hours for the precipitation and concentration tanks and the excess NaTPB was increased to $150 \%$ of stoichiometric. While this provided a better Cs decontamination, it was still not as required. At about this time some experimental work that had been in progress from Phase II was beginning to provide additional insight into the NaTPB reaction kinetics. With the preliminary data, a new reaction rate was determined and applied to both the CSTPB and KTPB reactions. These new reaction rates produced the required decontamination when coupled with the changes stated above.

The simulations were run by starting with an empty system. Feed was introduced to the first precipitate tank and allowed to progress through the system. In order to eliminate any start-up effects, the simulations were run for about 100 days. Most of the start-up variability was eliminated within the first 20 days, so taking results at 100 days provided a reliable steady-state solution for the continuous process. As mentioned above, the precipitate and concentration tanks were treated as continuous processes, while the wash tank was not. The wash tank presented some difficulty in interpreting results because of its batch operation. These difficulties are described below.

The wash tank operated on a fixed batch time of two days. The rate at which concentrated slurry was supplied to the accumulator tank did not correspond exactly to this time schedule. A plot of the volume of the wash tank showed an oscillating function with a major period of about. 30 days and minor periods corresponding to the individual washes. A comparison of the exit stream coming from the wash tank to that leaving the concentrate tank then showed an apparent mismatch. While everything appeared to be internally consistent within the two streams, the KTPB contained in each looked different: the stream leaving the concentrate tank contained about $1 \mathrm{lbm} / \mathrm{hr}$ while the wash tank stream contained about 1.2 $\mathrm{lbm} / \mathrm{hr}$. If the wash tank stream were averaged for the entire duration of the simulation, which was easily done by integrating the stream and dividing it by the time the wash operated, the average values of the wash stream matched those of the stream exiting the concentrate tank. The a.pparent differences, therefore, were not caused by a physical discrepancy in the model, but rather by the method of presenting results.

The results of the simulations showed what was expected except with one exception. It had been thought that the majority of the precipitation reactions would take place in the first precipitation tank, with second precipitation tank providing a slight improvement of cesium decontamination, and the concentration tank there solely to provide concentration. The simulations showed that the first precipitation tank provided about a 22 times decrease in cesium concentration, the second precipitation tank provided another 19 times, and the concentration tank provided the remaining 67 times decrease in soluble cesium concentration. These three tanks together provide a decontamination factor of about 28,000 , which was just slightly high enough to meet the downstream requirements for the decontaminated salt solution. The suggestion that the second precipitation tank and the concentration tanks have a shorter hold-up time than the first precipitation tank is not supported by these results.

If the Small Tank alternative should pass on to the next round, several improvements to the model would be necessary. Firstly, new data on reaction kinetics, tetraphenylborate degradation, and solubilities should be included. Secondly, the filter equations need to be redone. The present filter equations provide a rate of flow as a function of solids concentration, but this is only an approximation of actual filter performance. In the continuous process, a more realistic representation of the filter operation is needed. 
In addition, a simpler and more accurate representation would make the model more robust. Thirdly, and finally, the reaction kinetics should be rewritten to include both $\mathrm{xNO}_{3}$ and $\mathrm{xOH}$ compounds. Presently they only consider the $\mathrm{xNO}_{3}$ compounds, so a translation must be used to convert the $\mathrm{xOH}$ compounds in the input to $\mathrm{xNO}_{3}$ compounds. Then, even though the degradation reactions create both the $\mathrm{xNO}_{3}$ and $\mathrm{xOH}$ compounds, the precipitation equations include only the $\mathrm{xNO}_{3}$ compounds. Therefore, $\mathrm{KOH}$ and $\mathrm{CsOH}$ concentrations continue to increase. A thorough scrub of the model is required to assure all the appropriate equations consider both forms of the compounds.

\subsubsection{DWPF Model Results for Small Tank ITP Process}

The following table lists summary results from the DWPF calculation for the Small Tank TPB Precipitation process. Mass and volume results for the various flow streams and can production are yearly averages based on about 20 batch cycles in DWPF. The second section shows the instantaneous flow stream compositions throughout the model at the end of the run.

\section{Report SUMMARY}

$\begin{array}{crl}\begin{array}{c}\text { Problem time : } 3000.0 \mathrm{hr}= \\ \text { Integration interval } \\ \text { Can production: }\end{array} & 0.342 \mathrm{yr} \\ & 0.274 \mathrm{yr} \\ & 308.817 \mathrm{per} \text { year } \\ \text { Glass properties: } & & \\ \text { Durability: } & -7.271 & \\ \text { Viscosity: } & 47.424 & \\ \text { Liquidus: } & 1004.035 & \\ \text { Effective } & 0.317 & \\ \text { Percent_Ti: } & & \\ & 1328.252 \mathrm{kgal} / \mathrm{yr} \\ \text { Recycle volume: } & 59.557 \mathrm{kgal} / \mathrm{yr} \\ \text { Organic waste: } & 61.709 \mathrm{klbm} / \mathrm{yr} \\ \text { No2: } & & \end{array}$

PROCESS SUMMARY

Salt Cell (PRFT, PR, PRBT)

$\begin{array}{rlrr}\text { Item } & & \text { Mass }(\mathrm{klb} / \mathrm{Yr}) & \text { Volume }(\mathrm{Kgal} / \mathrm{Yr} \text { ) } \\ 57 & \text { PRFT to PR } & 4255.237 & 494.393 \\ 58 & \text { PHA to PRBT } & 5456.136 & 643.521 \\ 60 & \text { Copper nitrate } & 270.034 & 31.645 \\ 61 & \text { Formic to PR } & 205.728 & 20.726\end{array}$

Chemical Processing Cell (SRAT, SME, MFT)

$\begin{array}{clrr}\text { Item } & & \text { Mass (klb/yr) } & \text { Volume } \\ 68 & \text { Benzene to CIF } & 431.513 & 59.557 \\ 81 & \text { Sludge to SRAT } & 2835.358 & 310.253 \\ 82 & \text { MST to SRAT } & 5.154 & 0.621 \\ 83 & \text { Formic to SRAT } & 97.819 & 9.855 \\ 84 & \text { Nitric acid to SRAT } & 124.621 & 12.483 \\ 85 & \text { NaNO2 to RCT } & 222.188 & 20.963 \\ 86 & \text { Caustic to RCT } & 1149.015 & 101.532 \\ 87 & \text { Recycle H2O to TnkFrm } & 11178.643 & 1328.252 \\ 88 & \text { SRAT condensate } & 0.817 & \end{array}$




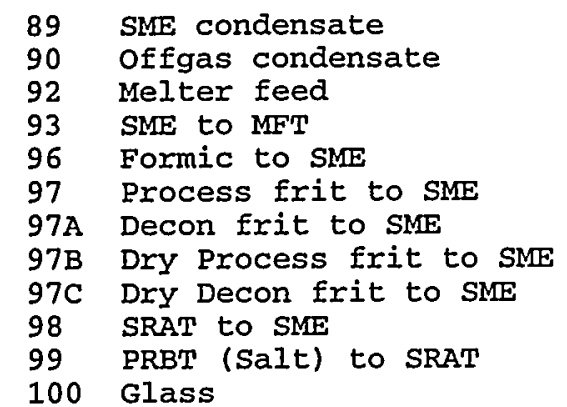

$\begin{array}{rr}0.502 & \\ 2848.909 & 250.942 \\ 2847.428 & 248.884 \\ 61.591 & 6.205 \\ 1149.261 & 93.074 \\ 1216.374 & 142.716 \\ 680.581 & \\ 57.084 & \\ 2568.937 & 274.281 \\ 5489.802 & 647.468 \\ 1191.355 & 55.653\end{array}$

\section{Report MASSFRACTION}

\begin{tabular}{|c|c|c|c|c|c|c|}
\hline time : & $\begin{array}{l}3000 . \\
\text { Precip_Feed } \\
\text { stream densi }\end{array}$ & & \multicolumn{2}{|c|}{ Input/Tank Mass Fractions } & & \\
\hline 1. & $\mathrm{H} 2 \mathrm{O}$ & : & 0.888000 & 2. Misc salts & $: 108.611000$ & $E-6$ \\
\hline 3. & NaNO3 & : & $2.010000 \mathrm{E}-3$ & 4. NaNO2 & $: 646.9621000$ & $E-6$ \\
\hline 5. & $\mathrm{NaOH}$ & : & $1.525000 \mathrm{E}-3$ & 6. KNO3 & $:$ & 0 \\
\hline 7. & CsNO3 & : & 0 & 8. NH4NO3 & : & 0 \\
\hline 9. & NH4OH & : & 0 & 10. NaAlO2 & $: 331.012000$ & $E-6$ \\
\hline 11. & Misc sludge & : & 0.010120 & 12. Na2U2O7 & $:$ & 0 \\
\hline 13. & $\mathrm{Fe}(\mathrm{OH}) 3$ & $:$ & 0 & 14. Al $(\mathrm{OH}) 3$ & $:$ & 0 \\
\hline 15. & $\mathrm{Sr}(\mathrm{OH}) 2$ & : & 0 & 16. Benzene & $:$ & 0 \\
\hline 17. & Phenol & & $35.388000 \mathrm{E}-6$ & 18. $\mathrm{CsOH}$ & $=1.016000$ & $E-6$ \\
\hline 19. & $\mathrm{KOH}$ & & $19.589000 \mathrm{E}-6$ & 20. CsTPB & $: \quad 2.145000$ & E-3 \\
\hline 21. & NaTPB & $: 41$ & $18.439000 \mathrm{E}-6$ & 22. NaDPB & $: 62.715000$ & $E-6$ \\
\hline 23. & KTPB & $:$ & 0.087620 & 24. NH4TPB & $: \quad 4.552000$ & $E-3$ \\
\hline 25. & NaTitanate & $:$ & $1.767000 \mathrm{E}-3$ & 26. NaT.Sr $(\mathrm{OH}) 2$ & $:$ & 0 \\
\hline 27. & $\mathrm{NaT} \cdot \mathrm{Na} 2 \mathrm{U} 2 \mathrm{O} 7$ & $: 45$ & $52.679000 \mathrm{E}-6$ & 28. (C6H5) 3B & : 17.220000 & E-6 \\
\hline 29 . & (C6H5) $2 \mathrm{BOH}$ & $:$ & 0 & 30. $(\mathrm{C} 6 \mathrm{H} 5) \mathrm{B}(\mathrm{OH}) 2$ & $2:$ & 0 \\
\hline 31. & $\mathrm{~B}(\mathrm{OH}) 3$ & $:$ & 0 & 32. K2O & $: 160.374000$ & $E-6$ \\
\hline 33 . & Li20 & $: 22$ & $21.115000 \mathrm{E}-6$ & 34. $\mathrm{MgO}$ & : & 0 \\
\hline 35 . & Mno & $:$ & 0 & 36. TiO2 & $:$ & 0 \\
\hline 37. & U308 & $:$ & 0 & 38. $\mathrm{ZrO} 2$ & $:$ & 0 \\
\hline 39. & $\mathrm{Ca} 3 \mathrm{P} 2 \mathrm{O} 8$ & $:$ & 0 & 40. P205 & $:$ & 0 \\
\hline 41. & $\mathrm{Cr} 2 \mathrm{O} 3$ & $:$ & 0 & 42. Cs2O & : & 0 \\
\hline 43 . & CuO & $:$ & 0 & 44. Na2O & : & 0 \\
\hline 45 . & NiO & $:$ & 0 & 46. SiO2 & : & 0 \\
\hline 47. & $\mathrm{HgO}$ & $:$ & 0 & 48. Alpha & $:$ & 0 \\
\hline 49. & $\mathrm{CaCO} 3$ & : & 0 & 50. $\mathrm{Na} 2 \mathrm{CO} 3$ & : & 0 \\
\hline 51. & $\mathrm{Na2SO} 4$ & : & 0 & 52. CaO & : & 0 \\
\hline 53. & A1203 & $:$ & 0 & 54. Fe2O3 & $:$ & 0 \\
\hline 55 & $\mathrm{Na} 3 \mathrm{PO} 4$ & $:$ & 0 & 56. Na2MoO4 & : & 0 \\
\hline 57 & HINO3 & : & 0 & 58. Caso4 & : & 0 \\
\hline 59 & $\mathrm{NaF}$ & : & 0 & 60. NaCl & : & 0 \\
\hline
\end{tabular}

Precip_Feed: Output Mass Fractions

stream density : $\quad 8.607000$ (1 $1 \mathrm{bm} / \mathrm{gal})$

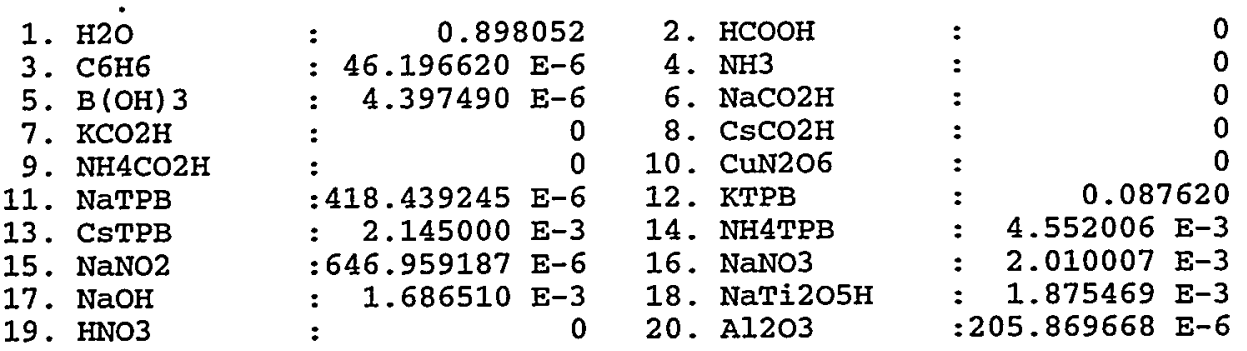




\begin{tabular}{|c|c|c|c|}
\hline 21. $\mathrm{B} 2 \mathrm{O} 3$ & : & 0 & 22. $\mathrm{BaO}$ \\
\hline 23. $\mathrm{CaO}$ & : & 0 & 24. Cr2O3 \\
\hline 25. Cs20 & : & 0.0 & 26. CuO \\
\hline 27. Fe203 & : & 0 & 28. K2O \\
\hline 29. Li20 & $: 221.115000$ & $E-6$ & 30. $\mathrm{MgO}$ \\
\hline 31. Mno & : & 0 & 32. $\mathrm{Na2O}$ \\
\hline 3. $\mathrm{NiO}$ & : & 0 & 34. SiO2 \\
\hline 5. TiO2 & : & 0 & 36. U308 \\
\hline 7. $\mathrm{ZrO2}$ & : & 0 & 38. Сa3P2O8 \\
\hline P205 & : & 0 & 40. $\mathrm{NaCl}$ \\
\hline $\mathrm{NaF}$ & : & 0 & 42. Na2SO4 \\
\hline Sro & : & 0 & 44. Alpha \\
\hline $\mathrm{HgO}$ & : & 0 & \\
\hline
\end{tabular}

\begin{tabular}{|c|c|}
\hline : & 0 \\
\hline : & C \\
\hline : & c \\
\hline$: 176.818 .157$ & $E-6$ \\
\hline : & 0 \\
\hline$: 33.647849$ & $E-6$ \\
\hline & 0 \\
\hline$: 304.7731549$ & $E-6$ \\
\hline & 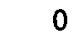 \\
\hline & C \\
\hline & \\
\hline & \\
\hline
\end{tabular}

SRAT Feed: Input PHA Mass Fractions stream density :

$8.478871(1 \mathrm{bm} / \mathrm{gal})$

1. $\mathrm{H} 2 \mathrm{O}$
3. $\mathrm{C} 6 \mathrm{H} 6$
5. $\mathrm{B}(\mathrm{OH}) 3$
7. $\mathrm{KCO} 2 \mathrm{H}$
9. $\mathrm{NH} 4 \mathrm{CO} 2 \mathrm{H}$
11. $\mathrm{NaTPB}$
13. $\mathrm{CsTPB}$
15. NaNO2
17. NaOH
19. HNO3
21. $\mathrm{B} 2 \mathrm{O} 3$
23. $\mathrm{CaO}$
25. Cs2O
27. Fe2O3
29. Li2O
31. MnO
33. NiO
35. TiO2
37. ZrO2
39. 2205
41. NaF
43. SrO
45. HgO

$\begin{array}{lrll}: & 0.938157 & 2 . \mathrm{HCOOH} \\ : & 0.0 & 4 . \mathrm{NH} 3 \\ : & 0.012389 & 6 . \mathrm{NaCO} 2 \mathrm{H} \\ : 645.755132 & \mathrm{E}-6 & 10 . \mathrm{CUNO} 2 \mathrm{H} \\ : & 0.015607 & 8.0 & 12 . \mathrm{KTPB} \\ : & -0.0 & 14 . \mathrm{NH} 4 \mathrm{TPB} \\ : 490.791313 & \mathrm{E}-6 & 16 . \mathrm{NaNO} \\ : & 1.279407 & \mathrm{E}-3 & 18 . \mathrm{NaTi} 2 \mathrm{O} \mathrm{H} \\ : & 0 & 20 . \mathrm{Al} 2 \mathrm{O} 3 \\ : & 0 & 22 . \mathrm{BaO} \\ : & 0.0 & 24 . \mathrm{Cr} 2 \mathrm{O} 3 \\ : & 0.0 & 26 . \mathrm{CuO} \\ : & 0.0 & 28 . \mathrm{K} 2 \mathrm{O} \\ : 167.740598 \mathrm{E}-6 & 30 . \mathrm{MgO} \\ : & 0.0 & 32 . \mathrm{Na} 2 \mathrm{O} \\ : & 0.0 & 34 . \mathrm{SiO} 2 \\ : & 0 & 36 . \mathrm{U} 308 \\ : & 0 & 38 . \mathrm{Ca} 3 \mathrm{P} 2 \mathrm{O} 8 \\ : & 0 & 40 . \mathrm{NaCl} \\ : & 0 & 42 . \mathrm{Na} 2 \mathrm{SO} 4 \\ : & 0 & 44 . \mathrm{Alpha} \\ & 0.0 & \end{array}$

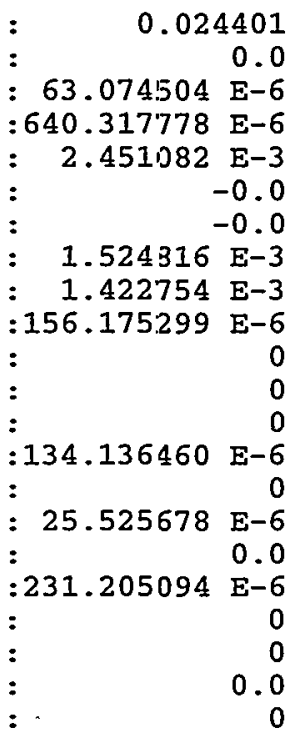

SRAT Feed: Sludge Input Mass Fractions stream density : $\quad 9.138866(\mathrm{Ibm} / \mathrm{gal})$
1. $\mathrm{H} 2 \mathrm{O}$
3. $\mathrm{B} 203$
5. $\mathrm{CaO}$
7. $\operatorname{cs} 20$
9. $\mathrm{Fe} 203$
11. Li2O
13. MnO
15. $\mathrm{NiO}$
17. TiO2
19. ZrO2
21. P205
23. NaF
25. SrO
27. HgO

$\begin{array}{lrr}: & 0.879010 \\ : & 0 \\ : & 2.813900 & \mathrm{E}-3 \\ : & 0.0 \\ : & 0.049460 \\ : & 7.519400 & \mathrm{E}-3 \\ : & 3.245200 & \mathrm{E}-3 \\ : & 10.731000 & \mathrm{E}-6 \\ : 800.920000 & \mathrm{E}-6 \\ : & 0 \\ : & 0 \\ : & 0.0 \\ : & 3.513200 & \mathrm{E}-3\end{array}$

2. A1203

4. $\mathrm{BaO}$

6. $\mathrm{Cr} 203$

8. CuO

10. $\mathrm{K} 2 \mathrm{O}$

12. $\mathrm{MgO}$

14. Na2O

16. SiO2

18. U308

20. Ca3P2O8

22. NaCl

24. $\mathrm{Na2SO} 4$

26. Alpha $\begin{array}{lrr}: & 0.016910 \\ : 474.480000 & E-6 \\ : 174.360000 & E-6 \\ : & 94.623000 & E-6 \\ : 822.780000 & E-6 \\ : & 0.017450 \\ : & 5.883500 & E-3 \\ : & 0.010520 \\ : & 1.105700 & E-3 \\ : & & 0 \\ : 141.040000 & E-6 \\ : & 49.177000 & E-6\end{array}$ 
SRAT : Output Mass Fractions

$$
\text { stream density : } \quad 9.366077 \text { (lbm/gal) }
$$

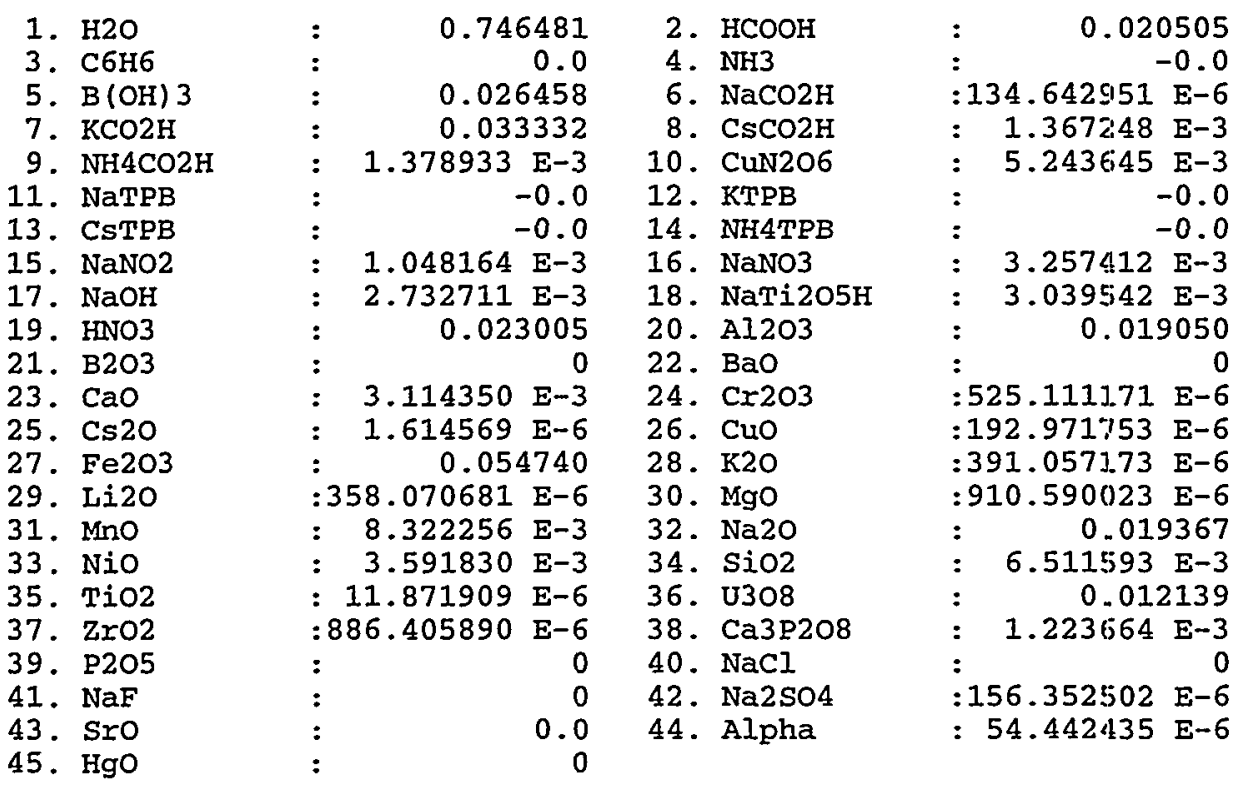

SME : Output Mass Fractions stream density : $\quad 11.440803$ (1bm/gal)

1. $\mathrm{H} 2 \mathrm{O}$

3. $\mathrm{C} 6 \mathrm{H} 6$

5. $\mathrm{B}(\mathrm{OH}) 3$

7. $\mathrm{KCO} 2 \mathrm{H}$

9. $\mathrm{NH} 4 \mathrm{CO} 2 \mathrm{H}$

11. NaTPB

13. CSTPB

15. NaNO2

17. $\mathrm{NaOH}$

19. HNO3

21. $\mathrm{B} 2 \mathrm{O} 3$

23. CaO

25. Cs2O

27. $\mathrm{Fe} 2 \mathrm{O} 3$

29. Li2O

31. Mno

33. NiO

35. TiO2

37. $\mathrm{ZrO} 2$

39. P205

41. NaF

43. Sro

45. HgO

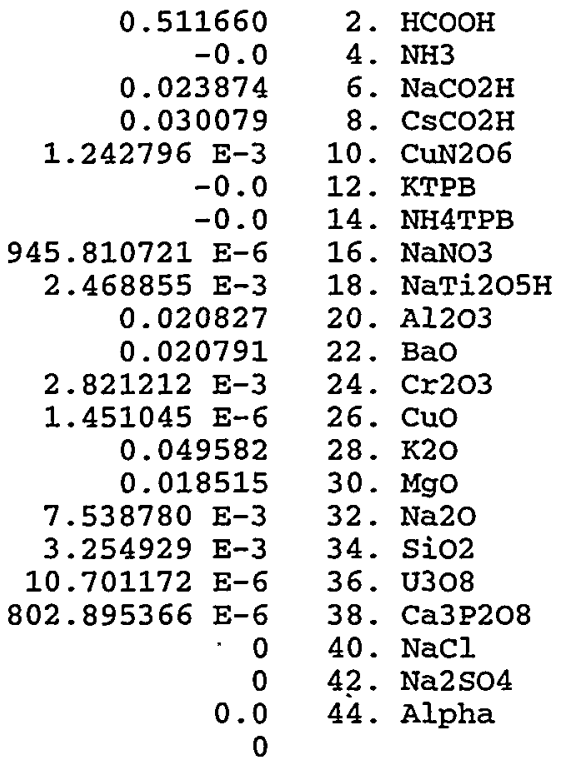

0.511660

0.023874

0.030079

$-0.0$

:945.810721 E-6

$1212 \mathrm{E}-3$

$1045 \mathrm{E}-6$

0.049582

0.018515

$7.538780 \mathrm{E}-3$

3.254929 E-3

.802 .895366 E-6

0
0
$: \quad 0.017490$
$: \quad 0.0$

$: 120.990591 \mathrm{E}-6$

: $1.231716 \mathrm{E}-3$

$4.742211 \mathrm{E}-3$

8.503.153 E-6

0.0

$2.947070 \mathrm{E}-3$

$2.751: 392 \mathrm{E}-3$

0.017262

:475.512519 E-6

$: 174.722744$ E-6

:352.164443 E-6

: $6.021 .392 \mathrm{E}-3$

: $\quad 0.033129$

: $\quad 0.206015$

0.011007

$1.107676 \mathrm{E}-3$

$\begin{array}{lr}: & 0 \\ & 143.833461 \text { E-6 }\end{array}$

: $49.386340 \mathrm{E}-6$

MFT : Output Mass Fractions

stream density :

$11.352855(1 \mathrm{bm} / \mathrm{gal})$

$\begin{aligned} \text { 1. } & \mathrm{H} 2 \mathrm{O} \\ \text { 3. } & \mathrm{C} 6 \mathrm{H} 6 \\ \text { 5. } & \mathrm{B}(\mathrm{OH}) 3 \\ \text { 7. } & \mathrm{KCO} 2 \mathrm{H} \\ \text { 9. } & \mathrm{NH} 4 \mathrm{CO} 2 \mathrm{H} \\ \text { 11. } & \text { NaTPB }\end{aligned}$

$\begin{array}{rl}0.511690 & \text { 2. } \mathrm{HCOOH} \\ 0.0 & \text { 4. } \mathrm{NH} 3 \\ 0.023955 & 6 . \mathrm{NaCO} 2 \mathrm{H} \\ 0.030177 & 8 . \mathrm{CsCO} 2 \mathrm{H} \\ 1.248589 \mathrm{E}-3 & \begin{aligned} 10 . \\ \mathrm{CuN} 2 \mathrm{O} 6\end{aligned} \\ -0.0 & 12 . \mathrm{KTPB}\end{array}$

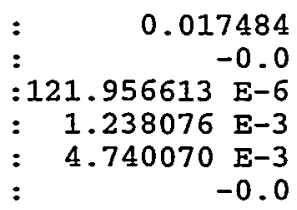


13. CsTPB

15. NaNO2

17. $\mathrm{NaOH}$

19. HNO3

21. $\mathrm{B} 203$

23. $\mathrm{CaO}$

25. $\operatorname{Cs} 20$

27. $\mathrm{Fe} 2 \mathrm{O} 3$

29. Li2O

31. Mno

33. NiO

35. TiO2

37. $\mathrm{ZrO} 2$

39. $\mathrm{P} 205$

41. NaF

43. Sro

45. HgO
: $\quad-0.0$ $: 948.965947 \mathrm{E}-6$ $2.473789 \mathrm{E}-3$ 0.020808 0.020797

$2.818089 \mathrm{E}-3$

$1.462409 \mathrm{E}-6$

0.049534

0.018523

7.530594 E-3

$3.250031 \mathrm{E}-3$

$10.746973 \mathrm{E}-6$

:802.112326 E-6

:

:

$:$
14. NH4TPB

16. NaNO3

18. NaTi2O5H

20. Al203

22. $\mathrm{BaO}$

24. Cr203

26. CuO

28. K2O

30. $\mathrm{MgO}$

32. $\mathrm{Na2O}$

34. SiO2

36. U308

38. Сa3P2O8

40. $\mathrm{NaCl}$

42. $\mathrm{Na25O4}$

44. Alpha

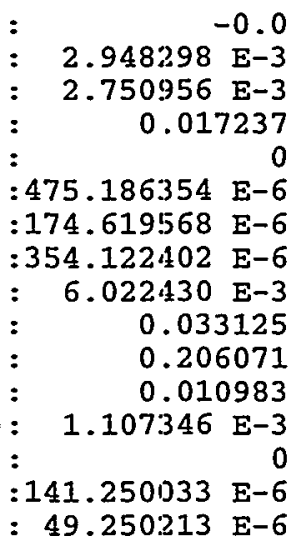

MELTER Output Mass Fractions

MELTER Output density:

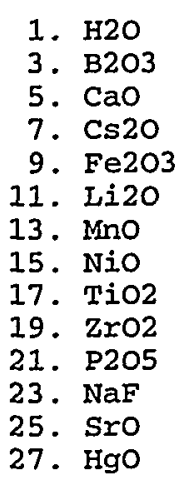

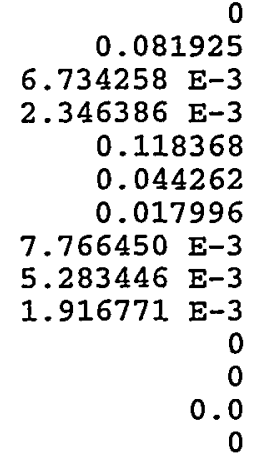

\section{$21.407009 \mathrm{lbm} / \mathrm{gal}$}

2. $\mathrm{Al2O} 3$
4. $\mathrm{BaO}$
6. $\mathrm{Cr} 2 \mathrm{O} 3$
8. $\mathrm{CuO}$
10. $\mathrm{K} 2 \mathrm{O}$
12. $\mathrm{MgO}$
14. $\mathrm{Na2O}$
16. $\mathrm{SiO} 2$
18. $\mathrm{U} 308$
20. Ca3P2O8
22. NaCl
24. Na2SO4
26. Alpha

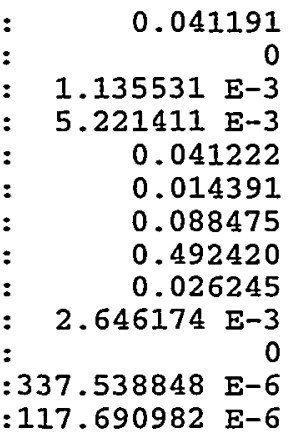

Recycle Mass Fractions

stream density : 8.416054 ( $1 \mathrm{bm} / \mathrm{gal})$

1. $\mathrm{H} 2 \mathrm{O}$

3. $\mathrm{C} 6 \mathrm{H} 6$

5. $\mathrm{BO} 3 \mathrm{H3}$

7. $\mathrm{KCO} 2 \mathrm{H}$

9. $\mathrm{NH} 4 \mathrm{CO} 2 \mathrm{H}$

11. NATPB

13. CSTPB

15. NaNO2

17. $\mathrm{NaOH}$

0.969266
0.0
0
0
0
0
0
0
$3.072608 \quad E-3$
0.019858

2. $\mathrm{CO} 2 \mathrm{H} 2$

4. $\mathrm{NH} 3$

6. $\mathrm{NaCO} 2 \mathrm{H}$

8. $\mathrm{CsCO} 2 \mathrm{H}$

10. CuN2O6

12. KTPB

14. NH4TPB

16. NaNO3

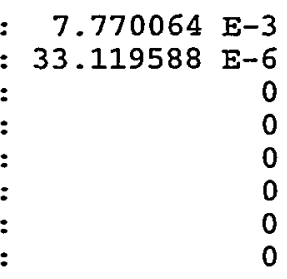




\section{CAUSTIC SIDE SOLVENT EXTRACTION}

\subsection{Solvent Extraction Material Balance Model}

\subsubsection{Model Description}

Figure 6.1 shows a schematic diagram of the Solvent Extraction material balance model. The alpha decontamination and grout production parts of this models are identical to those discussed with the Direct Grout model. The solvent extraction process adds a continuous counter-current solvent extraction operation to remove cesium from the salt solution in the SSHT prior to grouting. The solvent extraction model consists of three units:

1. An extraction unit where cesium is removed from the salt solution into an organic solvent. The aqueous effluent from the extraction stage is sent to the grout plant.

2. A scrubber where $0.5 \mathrm{M} \mathrm{NaOH}$ is added the aqueous phase that then enters the extraction unit.

3. A stripper where $0.01 \mathrm{M}$ nitric acid is used to strip the cesium from the organic phase back into the aqueous phase. The aqueous phase from the stripper is accumulated in a holding tank and added as an input stream to the DWPF model.

Parameters used for the model including the number of stages in each unit and the cesium distribution coefficients are listed in Table 6.1. The model assumes that cesium is the only component transferred between the different phases in the solvent extraction process.

Table 6.1. Parameters Used in Solvent Extraction Model

\begin{tabular}{|c|c|c|c|}
\hline Unit & Stages & Cesium, Kd & Feed Flow (gpm). \\
\hline Extraction & 16 & 8 & 5.7 solvent \\
\hline Scrubbing & 2 & 0.6 & $20 \%$ of solvent flow \\
\hline Stripping & 16 & 0.2 & 1.5 \\
\hline
\end{tabular}

The organic solvent used in the extraction unit is continuously recycled from the output of the stripping stages to the input of the extraction stages. A series of trial calculations showed that a flow rate of 5.7 gpm solvent minimized the amount of cesium retained in the raffinate stream going to saltstone. Figure 6.2 shows a plot of the model calculated results at various solvent flow rates for two levels of cesium in the incoming salt stream. The optimum solvent flow is independent of the incoming concentration and a relatively strong function of flow rate. The scrub flow was set to $20 \%$ of the solvent flow and the strip flow was fixed at $1.5 \mathrm{gpm}$. The flow of salt solution into the extraction unit will vary with the case study but is nominally in the range of 15 to $20 \mathrm{gpm}$.

\subsubsection{Comparison to TRUEX Literature Calculation}

A version of the SPEEDUP solvent extraction model was run to simulate the TRUEX process and model results were compared with literature values obtained using the SASSE code as reported in the paper by Leonard and Regalbuto. ${ }^{6.1}$ The model used for the comparison started with the SPEEDUP model employed in the Phase II and Phase III calculations and removed the alpha decontamination and grouting 
steps to leave just the solvent extraction portion of the model. The input was then modified to use the TRUEX process parameters as given in the citation.

Results from the SPEEDUP solvent extraction model compared well with most of the SASSE results although they were not in complete agreement. The original SPEEDUP model used a relatively simple representation of a counter-current extraction stage with two input streams and two output streams for the aqueous and organic phases. As an enhancement to this model (based on the description of the solvent extraction process in the SASSE article) the SPEEDUP model was modified to include carryover of the aqueous phase in the organic stream and of the organic phase in the aqueous stream. This modification approximately doubles the size of the model since it increases the number of flow streams by a factor of two. Using carryover ratios from the SASSE report, this modification improved the comparison between the SPEEDUP results and those reported for the SASSE code. For the four major output streams from the TRUEX process, the comparisons shown in the following tables were obtained.

Table 6.2 Comparison between SASSE and SPEEDUP Solvent Extraction models.

\begin{tabular}{|c|c|c|c|c|}
\hline \multirow[b]{2}{*}{ Component } & \multicolumn{2}{|c|}{$\begin{array}{c}\text { Extraction Stages } \\
\text { Raffinate }\end{array}$} & \multicolumn{2}{|c|}{$\begin{array}{l}\text { Strip \#1 Stages } \\
\text {. Am Product } \\
\end{array}$} \\
\hline & SASSE & SPEEDUP & SASSE & SPEEDUP \\
\hline $\mathrm{xi}$ (HNO3), M & 1.09 & 1.09 & 0.86 & 0.85 \\
\hline$x i(\mathrm{Am}), \mathrm{M}$ & $4 e-12$ & $4 e-12$ & $2 e-6$ & $2 e-6$ \\
\hline $\mathrm{xi}(\mathrm{Pu}), \mathrm{M}$ & $3 e-16$ & $2 e-16$ & $8 e-9$ & $8 \mathrm{e}-9$ \\
\hline$x i(\mathrm{Na}), \mathrm{M}$ & 0.27 & 0.27 & $3 e-4$ & $2 e-4$ \\
\hline $\mathrm{xi}(\mathrm{Al}), \mathrm{M}$ & 0.43 & 0.43 & $4 e-6$ & $2 e-7$ \\
\hline yi (HNO3), M & 0.54 & 0.55 & 0.20 & 0.20 \\
\hline yi $(\mathrm{Am}), \mathrm{M}$ & $1 e-10$ & $1 e-10$ & $1 e-5$ & $1 e-5$ \\
\hline yi $(\mathrm{Pu}), \mathrm{M}$ & $7 e-14$ & $3 e-14$ & $1 e-6$ & $1 e-6$ \\
\hline yi (Na), M & $5 e-3$ & $5 e-3$ & $5 e-6$ & $4 e-6$ \\
\hline yi (Al), M & $4 e-5$ & $4 e-5$ & $4 e-10$ & $2 \mathrm{e}-11$ \\
\hline
\end{tabular}


Table 6.3 Comparison between SASSE and SPEEDUP Solvent Extraction models.

\begin{tabular}{|l|c|c|c|c|}
\hline & \multicolumn{2}{|c|}{$\begin{array}{c}\text { Strip \#2 Stages } \\
\text { Pu Product }\end{array}$} & \multicolumn{2}{c|}{ Strip \#2 Stages } \\
& Solvent \\
\hline Component & SASSE & SPEEDUP & SASSE & SPEEDUP \\
\hline xi (HNO3), M & 0.05 & 0.05 & 0.05 & 0.05 \\
\hline xi (Am), M & $2 \mathrm{e}-5$ & $2 \mathrm{e}-5$ & $6 \mathrm{e}-6$ & $6 \mathrm{e}-6$ \\
\hline xi (Pu), M & $5 \mathrm{e}-6$ & $5 \mathrm{e}-6$ & $9 \mathrm{e}-8$ & $7 \mathrm{e}-8$ \\
\hline xi (Na), M & $3 \mathrm{e}-9$ & $1 \mathrm{e}-9$ & $3 \mathrm{e}-11$ & $1 \mathrm{e}-11$ \\
\hline xi (Al), M & $9 \mathrm{e}-14$ & 0 & $4 \mathrm{e}-17$ & 0 \\
\hline yi (HNO3), M & 0.002 & 0.002 & 0.002 & 0.002 \\
\hline yi (Am), M & $4 \mathrm{e}-6$ & $4 \mathrm{e}-6$ & $1 \mathrm{e}-6$ & $1 \mathrm{e}-6$ \\
\hline yi (Pu), M & $2 \mathrm{e}-7$ & $2 \mathrm{e}-7$ & $3 \mathrm{e}-9$ & $2 \mathrm{e}-9$ \\
\hline yi (Na), M & $6 \mathrm{e}-11$ & $3 \mathrm{e}-11$ & $5 \mathrm{e}-13$ & $2 \mathrm{e}-13$ \\
\hline yi (Al), M & $9 \mathrm{e}-18$ & 0 & $4 \mathrm{e}-21$ & 0 \\
\hline
\end{tabular}

$\mathrm{xi}=$ molar concentration in aqueous phase

$\mathrm{yi}=$ molar concentration in organic phase

Concentrations are rounded off to the precision reported for the SASSE results.

As can be seen from the above tables, results from the SPEEDUP solvent extraction model compare favorably with those from the SASSE code. This provides a verification and validation of the SPEEDUP results calculated in Phase II and Phase III. No attempt was made to follow the SASSE implementation of solvent extraction exactly. The existing SPEEDUP model, extended to include carryover, with a formulation independent of that used in the SASSE model was used to make: the comparisons. The somewhat different algorithms or machine precision may account for the remaining differences in the two sets of results.

The SPEEDUP formulation is significantly easier to extend to handle additional modifications such as solvent cleanup or direct linking to pre and post processing steps for the salt: streams than would be the spreadsheet version. The steady-state SPEEDUP code runs very quickly on the VAX alpha machines. The SPEEDUP code is also very compact using just a model of a single extraction stage and a macro for separate units in the extraction process (extraction, scrubbing and stripping) that builds each unit using as many stages as are specified in the operation section of the code. 


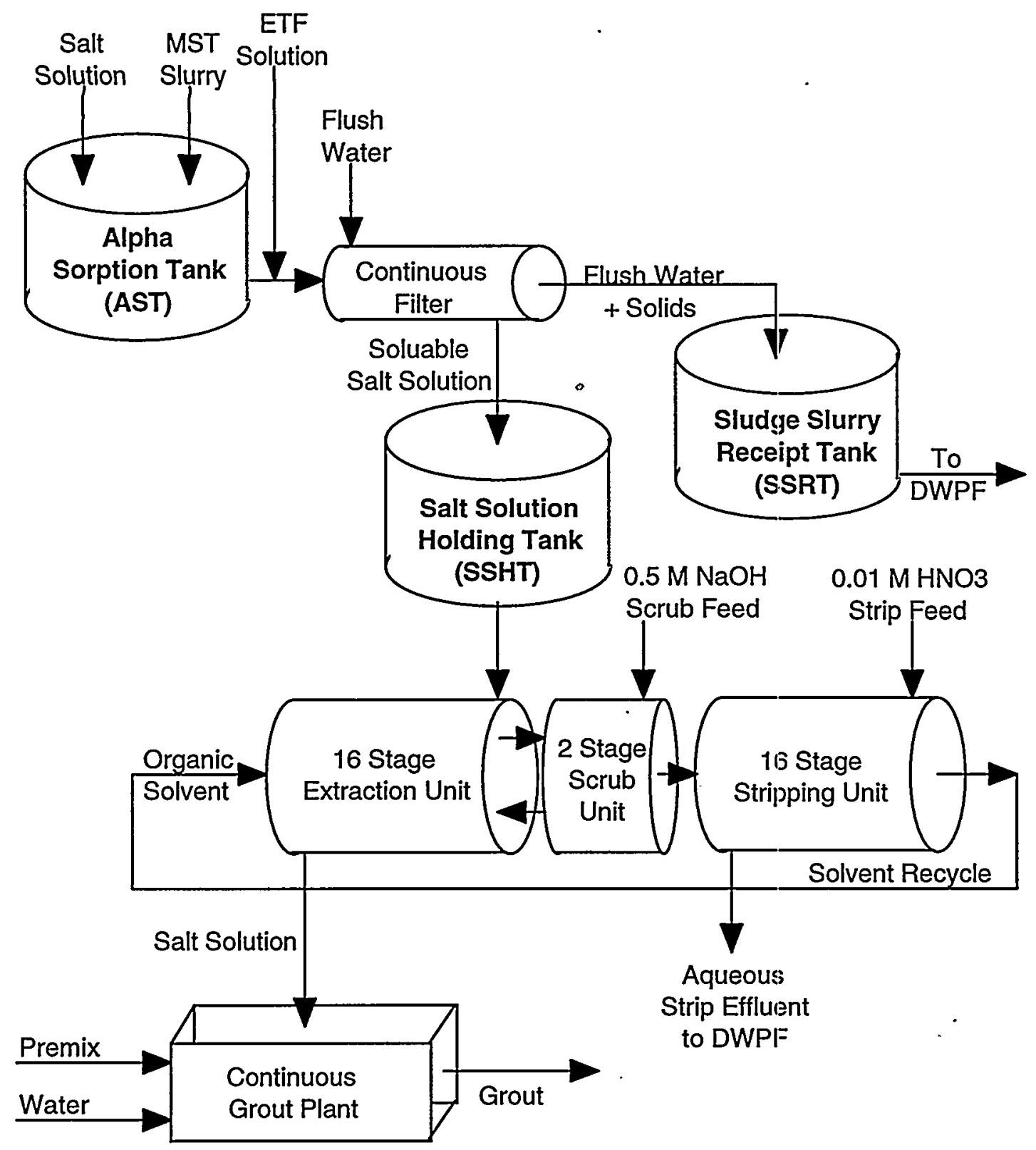

Figure 6.1 Schematic representation of Solvent Extraction Model. 


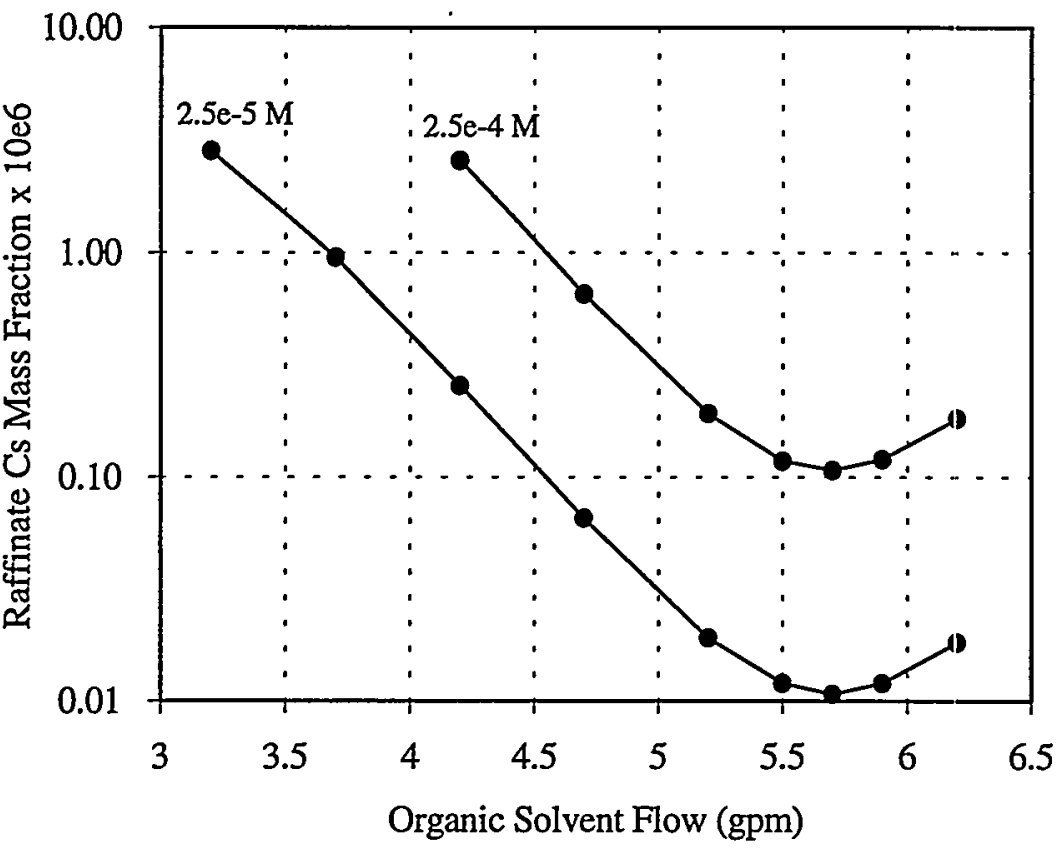

Figure 6.2 Plot of cesium concentration in raffinate vs. solvent flow at two levels of cesium in the salt solution.

\subsection{Solvent Extraction Model Results for FY 2012 Salt Blend}

The following output was obtained directly from report EXTRACT written by the SPEEDUP model from a representative calculation made with the Solvent Extraction model. This report shows the primary flow streams in the models and either the stream density or mass flowrate. As for the grout model, the first 35 hours of operation in the Solvent Extraction model are taken up processing the first batch through the alpha decontamination process. Thereafter (i.e. for the remaining 1441 hours of the simulation) the model is running continuously. The Waste Processed represents the volume of salt solution that has passed through the entire process.

The mass fractions reported in the second section of this output are instantarieous values for each of the flowstreams at the end of the run.

\section{Report EXTRACT}

$\begin{array}{rrr}\text { Simulation Time }= & 1476.000 \text { hours } & \\ \text { Operating Time }= & 1440.842 \text { hours } & \\ \text { Waste Sent to AST }= & 1560.003 \mathrm{kgal} & \begin{array}{r}9484.470 \mathrm{kgal} / \mathrm{yr} \\ 9172.494 \mathrm{kgal} / \mathrm{yr}\end{array} \\ \text { Waste Processed }= & 1508.689 \mathrm{kgal} & \\ \text { Processing Rate }= & 17.451 \mathrm{gpm} \\ \text { MST Volume Used }= & 16.202 \mathrm{kgal} & 98.503 \mathrm{kgal} / \mathrm{yr} \\ \text { AST Water Added }= & 100.238 \mathrm{kgal} & 609.423 \mathrm{kgal} / \mathrm{Yr}\end{array}$




\begin{tabular}{|c|c|c|c|c|c|}
\hline ETF Bottoms & $=$ & 29.380 & $\mathrm{kgal}$ & 178.624 & $\mathrm{kgal} / \mathrm{yr}$ \\
\hline $\begin{array}{r}\text { Grout Volume Made } \\
\text { Dilution Water } \\
\text { Caustic Flush }\end{array}$ & $\begin{array}{l}= \\
= \\
=\end{array}$ & $\begin{array}{r}3009.934 \\
-0.0 \\
86.412\end{array}$ & $\begin{array}{l}\mathrm{kgal} \\
\mathrm{kgal} \\
\mathrm{kgal}\end{array}$ & $\begin{array}{r}18299.732 \\
-0.0 \\
525.365\end{array}$ & $\begin{array}{l}\mathrm{kgal} / \mathrm{yr} \\
\mathrm{kgal} / \mathrm{yr} \\
\mathrm{kgal} / \mathrm{yr}\end{array}$ \\
\hline $\begin{array}{l}\text { Volume in AST } \\
\text { Volume in SSHT } \\
\text { Volume in SSRT } \\
\text { (SSRT --> DWPF) }\end{array}$ & $\begin{array}{l}= \\
= \\
=\end{array}$ & $\begin{array}{l}27.454 \\
23.860 \\
65.625\end{array}$ & $\begin{array}{l}\mathrm{kgal} \\
\mathrm{kgal} \\
\mathrm{kgal}\end{array}$ & 398.987 & $\mathrm{kgal} / \mathrm{yx}$ \\
\hline $\begin{array}{r}\text { Solvent Flow } \\
\text { Scrub Feed } \\
\text { Strip Feed }\end{array}$ & $\begin{array}{l}= \\
=\end{array}$ & $\begin{array}{r}5.700 \\
98.510 \\
129.618\end{array}$ & $\begin{array}{l}\text { gpm } \\
\text { kgal } \\
\mathrm{kgal}\end{array}$ & $\begin{array}{l}598.916 \\
788.047\end{array}$ & $\begin{array}{l}\mathrm{kgal} / \mathrm{yr} \\
\mathrm{kgal} / \mathrm{yr}\end{array}$ \\
\hline
\end{tabular}

1. Salt Solution Feed to AST

Salt Solution Density $\quad 10.6720 \mathrm{lb} / \mathrm{gal}$

\begin{tabular}{|c|c|c|c|c|c|}
\hline $\mathrm{H} 2 \mathrm{O}$ & 0.6718 & salt & $0.5600 \mathrm{E}-2$ & NaNO3 & 0.1655 \\
\hline $\mathrm{NaNO} 2$ & $0.2704 E-1$ & $\mathrm{NaOH}$ & $0.7582 \mathrm{E}-1$ & KNO3 & $0.6090 \mathrm{E}-4$ \\
\hline CsNO3 & 0 & NH4NO3 & $0.4890 \mathrm{E}-5$ & $\mathrm{NH} 4 \mathrm{OH}$ & 促 \\
\hline $\mathrm{NaA} 102$ & $0.2141 E-1$ & sludge & $0.3960 \mathrm{E}-3$ & $\mathrm{Na} 2 \mathrm{U} 207$ & $0.6930 \mathrm{E}-3$ \\
\hline $\mathrm{Fe}(\mathrm{OH}) 3$ & 0 & $\mathrm{AI}(\mathrm{OH}) 3$ & 0 & $\mathrm{Sr}(\mathrm{OH}) 2$ & 0 \\
\hline $\mathrm{C} 6 \mathrm{H} 6$ & 0 & C6H5OH & 0 & $\mathrm{CsOH}$ & $0.2120 \mathrm{E}-4$ \\
\hline $\mathrm{KOH}$ & $0.1010 \mathrm{E}-2$ & CsTPB & 0 & NaTPB & 0 \\
\hline NaDPB & 0 & KTPB & 0 & $\mathrm{NH} 4 \mathrm{TPB}$ & $\mathrm{c}$ \\
\hline MST & 0 & MSTSr & 0 & MSTU & C \\
\hline$(\mathrm{C} 6 \mathrm{H} 5) 3 B$ & 0 & (C6H5) $2 \mathrm{BOH}$ & 0 & $(\mathrm{C} 6 \mathrm{H} 5) \mathrm{B}(\mathrm{OH}) 2$ & \\
\hline $\mathrm{B}(\mathrm{OH}) 3$ & 0 & $\mathrm{~K} 2 \mathrm{O}$ & 0 & Li20 & \\
\hline $\mathrm{MgO}$ & 0 & Mno & 0 & TiO2 & \\
\hline U308 & 0 & $\mathrm{ZrO} 2$ & 0 & Ca3P208 & \\
\hline P2O5 & 0 & $\mathrm{Cr} 2 \mathrm{O} 3$ & 0 & $\mathrm{Cs} 2 \mathrm{O}$ & \\
\hline CuO & 0 & $\mathrm{Na} 2 \mathrm{O}$ & 0 & NiO & \\
\hline $\mathrm{SiO} 2$ & 0 & HgO & $0.4040 \mathrm{E}-4$ & PuO2 & \\
\hline $\mathrm{CaCO} 3$ & 0 & $\mathrm{Na} 2 \mathrm{CO} 3$ & $0.1537 \mathrm{E}-1$ & $\mathrm{Na} 2 \mathrm{SO} 4$ & 0.158 \\
\hline
\end{tabular}

2. ETF Solution Feed to AST

ETF Solution Density $\quad 10.4000 \mathrm{lb} / \mathrm{gal}$

\begin{tabular}{|c|c|c|c|c|c|}
\hline $\mathrm{H} 2 \mathrm{O}$ & 0.7000 & Salt & $0.1183 \mathrm{E}-1$ & $\mathrm{NaNO} 3$ & 0.2400 \\
\hline NaNO2 & $0.2250 \mathrm{E}-3$ & $\mathrm{NaOH}$ & $0.4790 \mathrm{E}-1$ & KNO3 & 0 \\
\hline CsNO3 & 0 & NH4NO3 & 0 & $\mathrm{NH} 4 \mathrm{OH}$ & 0 \\
\hline NaAlO2 & 0 & sludge & 0 & $\mathrm{Na} 2 \mathrm{U} 207$ & 0 \\
\hline $\mathrm{Fe}(\mathrm{OH}) 3$ & 0 & $\mathrm{Al}(\mathrm{OH}) 3$ & 0 & $\mathrm{Sr}(\mathrm{OH}) 2$ & 0 \\
\hline C6H 6 & 0 & $\mathrm{C} 6 \mathrm{H} 5 \mathrm{OH}$ & 0 & $\mathrm{CsOH}$ & 0 \\
\hline $\mathrm{KOH}$ & 0 & CsTPB & 0 & NaTPB & 0 \\
\hline NaDPB & 0 & KTPB & 0 & NH4TPB & 0 \\
\hline MST & 0 & MSTSr & 0 & MSTU & 0 \\
\hline$(\mathrm{C} 6 \mathrm{H} 5) 3 \mathrm{~B}$ & 0 & (C6H5) $2 \mathrm{BOH}$ & 0 & $(\mathrm{C} 6 \mathrm{H} 5) \mathrm{B}(\mathrm{OH}) 2$ & 0 \\
\hline $\mathrm{B}(\mathrm{OH}) 3$ & 0 & $\mathrm{~K} 20$ & 0 & Li20 & 0 \\
\hline Mgo & 0 & $\mathrm{MnO}$ & 0 & Tio2 & 0 \\
\hline U308 & 0 & $\mathrm{ZrO2}$ & 0 & $\mathrm{Ca} 3 \mathrm{P} 2 \mathrm{O} 8$ & 0 \\
\hline P2O5 & 0 & $\mathrm{Cr} 203$ & 0 & $\operatorname{Cs} 20$ & 0 \\
\hline Cuo & 0 & $\mathrm{Na2O}$ & 0 & NiO & 0 \\
\hline Sio2 & 0 & $\mathrm{HgO}$ & 0 & PuO2 & 0 \\
\hline $\mathrm{CaCO} 3$ & 0 & $\mathrm{Na} 2 \mathrm{CO} 3$ & 0 & $\mathrm{Na} 2 \mathrm{SO} 4$ & 0 \\
\hline
\end{tabular}

3. Filtrate in SSHT

Filtrate Solution Denisty $\quad 10.1341 \mathrm{Ib} / \mathrm{gal}$

$\begin{array}{lrlrlr}\text { H2O } & 0.6814 & \text { Salt } & 0.5501 \mathrm{E}-2 & \text { NaNO3 } & 0.1618 \\ \text { NaNO2 } & 0.2617 \mathrm{E}-1 & \text { NaOH } & 0.7303 \mathrm{E}-1 & \text { KNO3 } & 0.5894 \mathrm{E}-4 \\ \text { CSNO3 } & 0 & \text { NH4NO3 } & 0.4732 \mathrm{E}-5 & \text { NH4OH } & 0 \\ \text { NaAlO2 } & 0.2072 \mathrm{E}-1 & \text { Sludge } & 0.0 & \text { Na2U2O7 } & 0.7054 \mathrm{E}-6 \\ \text { Fe (OH) } 3 & 0 & \text { Al(OH) } 3 & 0 & \text { Sr (OH) } 2 & 0.0\end{array}$




$\begin{array}{lrlrlr}\text { C6H6 } & 0 & \text { C6H5OH } & 0 & \text { CsOH } & 0.2052 E-4 \\ \text { KOH } & 0.9775 E-3 & \text { CSTPB } & 0 & \text { NaTPB } & 0 \\ \text { NaDPB } & 0 & \text { KTPB } & 0 & \text { NH4TPB } & 0 \\ \text { MST } & 0.0 & \text { MSTSr } & 0.0 & \text { MSTU } & 0.0 \\ \text { (C6H5) 3B } & 0 & \text { (C6H5) 2BOH } & 0 & \text { (C6H5) B (OH) } 2 & 0 \\ \text { B (OH) 3 } & 0 & \text { K2O } & 0 & \text { Li2O } & 0 \\ \text { MgO } & 0 & \text { MnO } & 0 & \text { TiO2 } & 0 \\ \text { U3O8 } & 0 & \text { ZrO2 } & 0 & \text { Ca3P2O8 } & 0 \\ \text { P2O5 } & 0 & \text { Cr2O3 } & 0 & \text { Cs2O } & 0 \\ \text { CuO } & 0 & \text { Na2O } & 0 & \text { NiO } & 0 \\ \text { SiO2 } & 0 & \text { HgO } & 0.3910 E-4 & \text { PUO2 } & 0 \\ \text { CaCO3 } & 0 & \text { Na2CO3 } & 0.1487 E-1 & \text { Na2SO4 } & 0.1535 E-1\end{array}$

4. Composition of Filtered Sludge Solution in SSRT Sludge Solution Density $\quad 8.7518 \mathrm{lb} / \mathrm{gal}$

$\begin{array}{lrl}\text { H2O } & 0.9246 & \text { Salt } \\ \text { NaNO2 } & 0 & \text { NaOH } \\ \text { CsNO3 } & 0 & \text { NH4NO3 } \\ \text { NaA1O2 } & 0 & \text { Sludge } \\ \text { Fe(OH) } 3 & 0 & \text { Al(OH) 3 } \\ \text { C6H6 } & 0 & \text { C6H5OH } \\ \text { KOH } & 0 & \text { CsTPB } \\ \text { NaDPB } & 0 & \text { KTPB } \\ \text { MST } & 0.2516 E-2 & \text { MSTSr } \\ \text { (C6H5) 3B } & 0 & \text { (C6H5) 2BOH } \\ \text { B(OH) 3 } & 0 & \text { K2O } \\ \text { MgO } & 0 & \text { MnO } \\ \text { U3O8 } & 0 & \text { ZrO2 } \\ \text { P2O5 } & 0 & \text { Cr2O3 } \\ \text { CuO } & 0 & \text { Na2O } \\ \text { SiO2 } & 0 & \text { HgO } \\ \text { CaCO3 } & 0 & \text { Na2CO3 }\end{array}$

$\begin{array}{rlr}0 & \text { NaNO3 } & 0 \\ 0.2000 \mathrm{E}-1 & \text { KNO3 } & 0 \\ 0 & \text { NH4OH } & 0 \\ 0.1131 \mathrm{E}-1 & \mathrm{Na2U2O} 7 & 0 \\ 0 & \mathrm{Sr}(\mathrm{OH}) 2 & 0 \\ 0 & \mathrm{CSOH} & 0 \\ 0 & \mathrm{NaTPB} & 0 \\ 0 & \text { NH4TPB } & 0 \\ -0.0 & \text { MSTU } & 0 \\ 0 & \text { (C6H5) B (OH) } 2 & 0 \\ 0 & \text { Li2O } & 0 \\ 0 & \text { TiO2 } & 0 \\ 0 & \text { Ca3P2O8 } & 0 \\ 0 & \text { Cs2O } & 0 \\ 0 & \text { NiO } & 0 \\ 0 & \text { PuO2 } & 0 \\ 0 & \text { Na2SO4 } & \end{array}$

5. Strip stage Effluent Composition Strip Effluent Flow $0.7512 \mathrm{klb} / \mathrm{hr}$

$\begin{array}{lrlrlr}\text { H2O } & 0.9994 & \text { Salt } & 0 & \text { NaNO3 } & 0 \\ \text { NaNO2 } & 0 & \text { NaOH } & 0 & \text { KNO3 } & 0 \\ \text { CsNO3 } & 0 & \text { HNO3 } & 0.6300 E-3 & \text { NH4OH } & 0 \\ \text { NaAlO2 } & 0 & \text { Sludge } & 0 & \text { Na2U2O7 } & 0 \\ \text { Fe (OH) } 3 & 0 & \text { Al (OH) } 3 & 0 & \text { Sr (OH) } 2 & 0 \\ \text { C6H6 } & 0 & \text { C6H5OH } & 0 & \text { CsOH } & 0.3405 E-3 \\ \text { KOH } & 0 & \text { CsTPB } & 0 & \text { NaTPB } & 0 \\ \text { NaDPB } & 0 & \text { KTPB } & 0 & \text { NH4TPB } & 0 \\ \text { MST } & 0 & \text { MSTSr } & 0 & \text { MSTU } & 0 \\ \text { (C6H5) 3B } & 0 & \text { (C6H5) 2BOH } & 0 & \text { (C6H5) B (OH) } 2 & 0 \\ \text { B (OH) 3 } & 0 & \text { K2O } & 0 & \text { Li2O } & 0 \\ \text { MgO } & 0 & \text { MnO } & 0 & \text { TiO2 } & 0 \\ \text { U3O8 } & 0 & \text { ZrO2 } & 0 & \text { Ca3P2O8 } & 0 \\ \text { P2O5 } & 0 & \text { Cr2O3 } & 0 & \text { Cs2O } & 0 \\ \text { CuO } & 0 & \text { Na2O } & 0 & \text { NiO } & 0 \\ \text { SiO2 } & 0 & \text { HgO } & 0 & \text { PuO2 } & 0 \\ \text { CaCO3 } & 0 & \text { Na2CO3 } & 0 & \text { Na2SO4 } & 0\end{array}$

6. Grout Plant Salt Solution Feed Flow and Composition

Salt Solution Flow $\quad 13.2944 \mathrm{klb} / \mathrm{hr}$

\begin{tabular}{|c|c|c|c|c|c|}
\hline $\begin{array}{l}\mathrm{H} 2 \mathrm{O} \\
\mathrm{NaNO} 2\end{array}$ & $\begin{array}{r}0.6998 \\
2394 E-1\end{array}$ & Salt & $\begin{array}{l}0.5032 \mathrm{E}-2 \\
0.7559 \mathrm{E}-1\end{array}$ & $\begin{array}{l}\text { NaNO3 } \\
\text { KNO3 }\end{array}$ & $\begin{array}{r}0.1480 \\
0.5391 E-4\end{array}$ \\
\hline CsNO3 & 0 & NH4NO3 & $0.4329 \mathrm{E}-5$ & $\mathrm{NH} 4 \mathrm{OH}$ & \\
\hline NaAlo2 & $0.1895 \mathrm{E}-1$ & sludge & 0.0 & Na2U2O7 & $0.6453 \mathrm{E}-6$ \\
\hline $\mathrm{Fe}(\mathrm{OH}) 3$ & 0 & $\mathrm{AI}(\mathrm{OH}) 3$ & 0 & $\mathrm{Sr}(\mathrm{OH}) 2$ & 0.0 \\
\hline $\mathrm{C} 6 \mathrm{H} 6$ & 0 & $\mathrm{C} 6 \mathrm{H} 5 \mathrm{OH}$ & 0 & $\mathrm{CsOH}$ & $0.3749 E-$ \\
\hline $\mathrm{KOH}$ & $0.8941 \mathrm{E}-3$ & CsTPB & 0 & NaTPB & \\
\hline
\end{tabular}




$\begin{array}{lrlrlr}\text { NaDPB } & 0 & \text { KTPB } & 0 & \text { NH4TPB } & 0 \\ \text { MST } & 0.0 & \text { MSTSr } & 0.0 & \text { MSTU } & 0.0 \\ \text { (C6H5) 3B } & 0 & \text { (C6H5) 2BOH } & 0 & \text { (C6H5)B(OH) } 2 & 0 \\ \text { B (OH) 3 } & 0 & \text { K2O } & 0 & \text { Li2O } & 0 \\ \text { MgO } & 0 & \text { MnO } & 0 & \text { TiO2 } & 0 \\ \text { U3O8 } & 0 & \text { ZrO2 } & 0 & \text { Ca3P2O8 } & 0 \\ \text { P2O5 } & 0 & \text { Cr2O3 } & 0 & \text { Cs2O } & 0 \\ \text { CuO } & 0 & \text { Na2O } & 0 & \text { NiO } & 0 \\ \text { SiO2 } & 0 & \text { HgO } & 0.3577 E-4 & \text { PuO2 } & 0 \\ \text { CaCO3 } & 0 & \text { Na2CO3 } & 0.1361 E-1 & \text { Na2SO4 } & 0.1404 E-1\end{array}$

7. Grout Plant Premix Feed Flow and Composition Premix Flow $\quad 16.3216 \mathrm{klb} / \mathrm{hr}$

$\begin{array}{lrl}\text { H2O } & 0 & \text { Salt } \\ \text { NaNO2 } & 0 & \text { NaOH } \\ \text { CsNO3 } & 0 & \text { NH4NO3 } \\ \text { NaAlO2 } & 0 & \text { Sludge } \\ \text { Fe (OH) } 3 & 0.2490 \mathrm{E}-1 & \text { Al(OH) 3 } \\ \text { C6H6 } & 0 & \text { C6H5OH } \\ \text { KOH } & 0 & \text { CsTPB } \\ \text { NaDPB } & 0 & \text { KTPB } \\ \text { MST } & 0.1190 \mathrm{E}-1 & \text { MSTSr } \\ \text { (C6H5) 3B } & 0 & \text { (C6H5) 2BOH } \\ \text { B (OH) } 3 & 0 & \text { K2O } \\ \text { MgO } & 0.5970 E-1 & \text { MnO } \\ \text { U3O8 } & 0 & \text { ZrO2 } \\ \text { P2O5 } & 0.7000 E-3 & \text { Cr2O3 } \\ \text { CuO } & 0 & \text { Na2O } \\ \text { SiO2 } & 0.4755 & \text { HgO } \\ \text { CaCO3 } & 0 & \text { Na2CO3 }\end{array}$

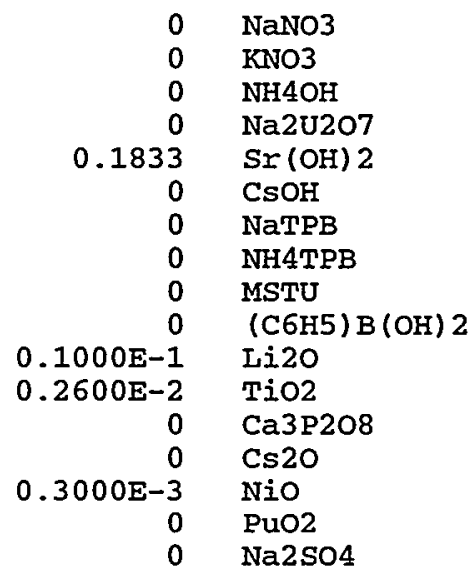

0
0
0
0
$0.2000 \mathrm{E}-3$
0
0
0
0
0
0
0
0.2268
0
0
0
$0.5000 \mathrm{E}-2$

8. Grout Flow and Composition Grout Flow $\quad 29.6160 \mathrm{klb} / \mathrm{hr}$

\begin{tabular}{|c|c|c|c|c|c|}
\hline $\begin{array}{l}\mathrm{H} 2 \mathrm{O} \\
\mathrm{NaNO} 2\end{array}$ & $\begin{array}{r}0.3141 \\
0.1075 \mathrm{E}-1\end{array}$ & $\begin{array}{l}\text { Salt } \\
\text { NaOH }\end{array}$ & $\begin{array}{l}0.2259 \mathrm{E}-2 \\
0.3393 \mathrm{E}-1\end{array}$ & $\begin{array}{l}\text { NaNO3 } \\
\text { KNO3 }\end{array}$ & $\begin{array}{l}0.6646 \mathrm{E}-1 \\
0.2420 \mathrm{E}-4\end{array}$ \\
\hline CsNO3 & 0 & NH4NO3 & $0.1943 E-5$ & $\mathrm{NH} 4 \mathrm{OH}$ & \\
\hline $\mathrm{NaA1O} 2$ & $0.8508 \mathrm{E}-2$ & sludge & 0.0 & $\mathrm{Na} 2 \mathrm{U} 2 \mathrm{O} 7$ & $0.2897 \mathrm{E}-6$ \\
\hline $\mathrm{Ee}(\mathrm{OH}) 3$ & $.1372 \mathrm{E}-1$ & $\mathrm{Al}(\mathrm{OH}) 3$ & 0.1010 & $\mathrm{Sr}(\mathrm{OH}) 2$ & 1102 \\
\hline $\mathrm{C} 6 \mathrm{H} 6$ & 0 & $\mathrm{C} 6 \mathrm{H} 5 \mathrm{OH}$ & 0 & $\mathrm{CsOH}$ & $0.1683 \mathrm{E}-$ \\
\hline $\mathrm{KOH}$ & $0.4014 \mathrm{E}-3$ & CSTPB & 0 & NaTPB & \\
\hline NaDPB & 0 & KTPB & 0 & NH4TPB & \\
\hline MST & $0.6558 \mathrm{E}-2$ & MSTSr & 0.0 & MSTU & 0. \\
\hline (C6H5) 3B & 0 & $(\mathrm{C} 6 \mathrm{H} 5) 2 \mathrm{BOH}$ & 0 & $(\mathrm{C} 6 \mathrm{H} 5)$ B $(\mathrm{OH}) 2$ & \\
\hline $\mathrm{B}(\mathrm{OH}) 3$ & 0 & K2O & $0.5511 \mathrm{E}-2$ & Ii20 & \\
\hline $\mathrm{MgO}$ & $0.3290 \mathrm{E}-1$ & Mno & $0.1433 \mathrm{E}-2$ & TiO2 & \\
\hline U308 & 0 & $\mathrm{ZrO2}$ & 0 & Ca3P208 & 0.1250 \\
\hline P2O5 & $0.3858 \mathrm{E}-3$ & $\mathrm{C} \times 2 \mathrm{O} 3$ & 0 & $\mathrm{Cs} 2 \mathrm{O}$ & \\
\hline CuO & 0 & $\mathrm{Na2O}$ & $0.1653 E-3$ & NiO & \\
\hline iO2 & 0.2621 & $\mathrm{HgO}$ & $0.1605 E-4$ & PuO2 & \\
\hline $\mathrm{aCO} 3$ & 0 & $\mathrm{Na} 2 \mathrm{CO} 3$ & $0.6108 \mathrm{E}-2$ & $\mathrm{Na} 2 \mathrm{SO} 4$ & 0.90581 \\
\hline
\end{tabular}




\subsection{DWPF Model Results for Solvent Extraction Process}

The following table lists summary results from the DWPF calculation for the Solvent Extraction process. Mass and volume results for the various flow streams and can production are yearly averages based on about 20 batch cycles in DWPF. The second section shows the instantaneous flow stream compositions throughout the model at the end of the run.

\section{Report SUMMARY}

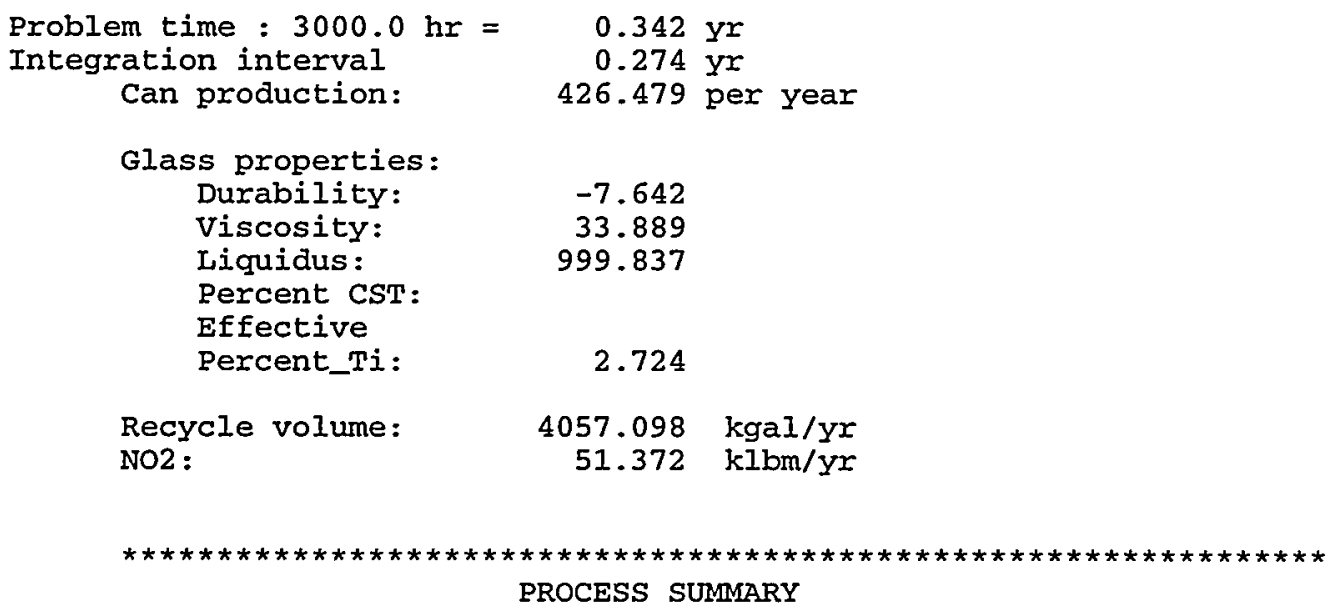

Chemical Processing Cell (SRAT, SME, MFT)

$\begin{array}{cl}\text { Item } & \\ 80 & \text { Sludge to SRAT } \\ 81 & \text { Salt to SRAT } \\ 82 & \text { MST to SRAT } \\ 83 & \text { Formic to SRAT } \\ 84 & \text { Nitric acid to SRAT } \\ 85 & \text { NaNO2 to RCT } \\ 86 & \text { Caustic to RCT } \\ 87 & \text { Recycle H20 to TnkFrm } \\ 88 & \text { SRAT condensate } \\ 89 & \text { SME condensate } \\ 90 & \text { Offgas condensate } \\ 91 & \text { Melter feed } \\ 92 & \text { SME to MFT } \\ 93 & \text { Formic to SME } \\ 94 & \text { SME Redox number } \\ 95 & \text { Process frit to SME } \\ 96 & \text { Decon frit to SME } \\ 97 & \text { Process dryfrit to SME } \\ 98 & \text { Decon dryfrit to SME } \\ 99 & \text { SRAT to SME } \\ 100 & \text { PRBT (Salt) to SRAT } \\ 101 & \text { Glass }\end{array}$

$\begin{array}{rr}\text { Mass }(\mathrm{klb} / \mathrm{yr}) & \text { Volume } \\ 3335.710 & 365.003 \\ 6317.821 & 760.638 \\ 3492.855 & 399.162 \\ 108.688 & 10.950 \\ 132.926 & 13.315 \\ 261.107 & 24.635 \\ 1351.610 & 119.434 \\ 34116.107 & 4057.098 \\ 0.608 & \\ 0.401 & \\ 3817.422 & 331.177 \\ 3657.992 & 326.630 \\ 72.457 & 7.300 \\ & \\ 1690.972 & 137.351 \\ 1430.794 & 167.901 \\ 1001.377 & \\ 67.147 & \\ 2984.180 & 303.622 \\ 6317.821 & 760.638 \\ 1693.015 & 75.762\end{array}$




\section{Report MASSFRACTION}

time : $\quad 3000.0$

SRAT Feed: Input Salt Mass Fractions

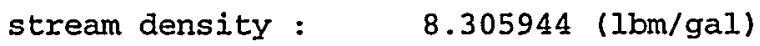

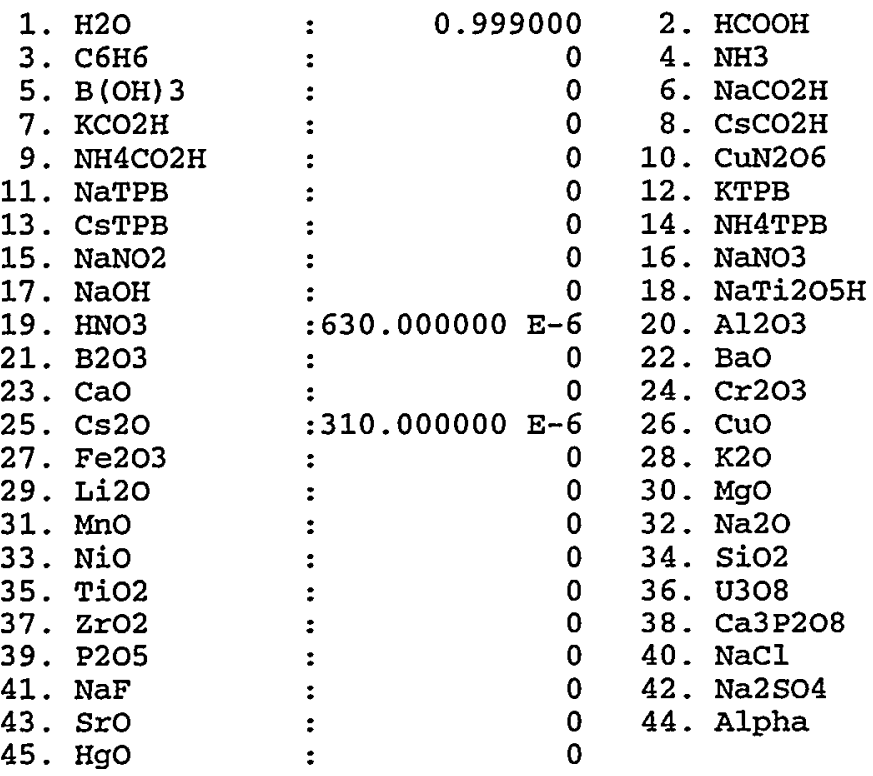

SRAT Feed: Alpha Decontamination stream stream density : $\quad 8.750463$ (1bm/gal)

\begin{tabular}{|c|c|c|c|}
\hline 1. $\mathrm{H} 2 \mathrm{O}$ & 0.924600 & 2. $\mathrm{HCOOH}$ & 0 \\
\hline 3. $\mathrm{C} 6 \mathrm{H} 6$ & : & 4. $\mathrm{NH3}$ & 0 \\
\hline 5. $\mathrm{B}(\mathrm{OH}) 3$ & : & 6. $\mathrm{NaCO} 2 \mathrm{H}$ & 0 \\
\hline 7. $\mathrm{KCO} 2 \mathrm{H}$ & : & 8. $\mathrm{CsCO} 2 \mathrm{H}$ & 0 \\
\hline 9. $\mathrm{NH} 4 \mathrm{CO} 2 \mathrm{H}$ & : & 10. Cun206 & 0 \\
\hline 11. NaTPB & : & 12. KTPB & 0 \\
\hline 13. CsTPB & : & 14. NH4TPB & $:$ \\
\hline 15. NaNO2 & : & 16. NaNO3 & : \\
\hline 17. $\mathrm{NaOH}$ & 0.020000 & 18. NaTi205H & 0.027450 \\
\hline 19. HNO3 & 0 & 20. A1203 & $1.600000 \mathrm{E}-3$ \\
\hline 21. B2O3 & : & 22. $\mathrm{BaO}$ & : \\
\hline 23. $\mathrm{CaO}$ & $: 266.000000 \mathrm{E}-6$ & 24. $\operatorname{Cr} 203$ & $=44.900000 \mathrm{E}-$ \\
\hline 5. $\operatorname{Cs} 20$ & $:$ & 26. CuO & $=16.500000 \mathrm{E}-$ \\
\hline 7. $\mathrm{Fe} 2 \mathrm{O} 3$ & $4.680000 \mathrm{E}-3$ & 28. K2O & $8.960000 \mathrm{E}-$ \\
\hline 9. Li20 & : & 30. $\mathrm{MgO}$ & $=77.9001000 \mathrm{E}-$ \\
\hline 1. $\mathrm{MnO}$ & $: 711.000000 \mathrm{E}-6$ & 32. $\mathrm{Na} 2 \mathrm{O}$ & $1.6801000 \mathrm{E}-$ \\
\hline NiO & $: 307.000000 \mathrm{E}-6$ & 34. $\mathrm{SiO} 2$ & $: 557.0001000 \mathrm{E}-$ \\
\hline TiO2 & $: 143.000000 \mathrm{E}-6$ & 36. U308 & 0.016620 \\
\hline $\mathrm{ZIO2}$ & $: 75.700000 \mathrm{E}-6$ & 38. Сa3P2O8 & $: 105.0001000 \mathrm{E}-6$ \\
\hline P205 & : & 40. $\mathrm{NaCl}$ & : \\
\hline $\mathrm{NaF}$ & : & 42. $\mathrm{Na} 2 \mathrm{SO} 4$ & $=13.3001000 \mathrm{E}-6$ \\
\hline Sro & 0.0 & 44. Alpha & $4.6601000 \mathrm{E}-$ \\
\hline $\mathrm{HgO}$ & : & & \\
\hline
\end{tabular}


SRAT Feed: Sludge Input Mass Fractions stream density : $\quad 9.138866$ (1 $9 \mathrm{bm} / \mathrm{gal})$

\begin{tabular}{|c|c|c|c|}
\hline 1. $\mathrm{H} 2 \mathrm{O}$ & 0.87 & 9010 & 2. $\mathrm{A} 1203$ \\
\hline 3. $\mathrm{B} 203$ & : & 0 & 4. $\mathrm{BaO}$ \\
\hline 5. $\mathrm{CaO}$ & 2.813900 & $E-3$ & 6. Cr203 \\
\hline 7. $\operatorname{Cs} 20$ & : & 0.0 & 8. CuO \\
\hline 9. Fe2O3. & 0.04 & 9460 & 10. $\mathrm{K} 20$ \\
\hline 11. Li20 & : & 0 & 12. MgO \\
\hline 13. $\mathrm{MnO}$ & 7.519400 & $E-3$ & 14. Na2O \\
\hline 15. NiO & 3.245200 & E-3 & 16. SiO2 \\
\hline 17. TiO2 & $=10.731000$ & E- 6 & 18. U308 \\
\hline 19. $\mathrm{ZrO} 2$ & $: 800.920000$ & E-6 & 20. Сa3 208 \\
\hline 21. P205 & : & 0 & 22. NaCl \\
\hline 23. NaF & : & 0 & 24. Na2SO4 \\
\hline 25. Sro & : & 0.0 & 26. Alpha \\
\hline 27. $\mathrm{HgO}$ & 3.513200 & $E-3$ & \\
\hline
\end{tabular}

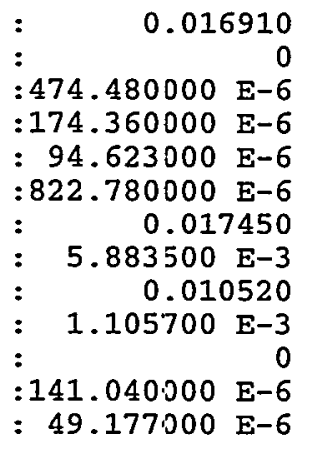

SRAT : Output Mass Fractions stream density : $\quad 9.828617$ (1bm/gal)

\begin{tabular}{|c|c|c|c|c|c|}
\hline 1. $\mathrm{H} 2 \mathrm{O}$ & 0.765 & 841 & 2. $\mathrm{HCOOH}$ & 1.653916 & E-3 \\
\hline 3. $\mathrm{C} 6 \mathrm{H} 6$ & : & 0.0 & 4. $\mathrm{NH} 3$ & 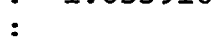 & 0.0 \\
\hline 5. $\mathrm{B}(\mathrm{OH}) 3$ & : & 0.0 & 6. $\mathrm{NaCO} 2 \mathrm{H}$ & : & 0 \\
\hline 7. $\mathrm{KCO} 2 \mathrm{H}$ & : & 0.0 & 8. $\mathrm{CsCO} 2 \mathrm{H}$ & $:$ & 0 \\
\hline 9. $\mathrm{NH} 4 \mathrm{CO} 2 \mathrm{H}$ & : & 0.0 & 10. CuN206 & : & 0.0 \\
\hline 11. NaTPB & : & 0 & 12. KTPB & : & 0.0 \\
\hline 13. CsTPB & : & 0 & 14. NH4TPB & : & 0.0 \\
\hline 15. NaNO2 & : & 0.0 & 16. $\mathrm{NaNO}$ & : & 0.0 \\
\hline 17. NaOH & 0.022 & 8303 & 18. $\mathrm{NaTi} 205 \mathrm{H}$ & 0.030 & 0610 \\
\hline 19. HNO3 & 0.022 & 2495 & 20. A1203 & 0.019 & 9800 \\
\hline 21. B2O3 & : & 0 & 22. $\mathrm{BaO}$ & $:$ & 0 \\
\hline 23. $\mathrm{CaO}$ & $=3.294460$ & $\mathrm{E}-3$ & 24. Cr203 & $=555.563910$ & $\mathbf{E}-6$ \\
\hline 25. Cs2O & $: 646.944392$ & $\mathrm{E}-6$ & 26. CuO & $: 204.157034$ & E-6 \\
\hline 27. $\mathrm{Fe} 2 \mathrm{O} 3$ & 0.057 & 7912 & 28. K2O & $: 110.799540$ & E-6 \\
\hline 29. Li20 & $:$ & 0 & 30. $\mathrm{MgO}$ & $: 963.428320$ & E-6 \\
\hline 31. Mno & 8.803776 & $E-3$ & 32. $\mathrm{Na2O}$ & 0.020 & 0464 \\
\hline 33. NiO & 3.799679 & $\mathrm{E}-3$ & 34. SiO2 & $6.889: 208$ & $E-3$ \\
\hline 35. TiO2 & $: 170.895869$ & $\mathrm{E}-6$ & 36. U308 & 0.029 & 9741 \\
\hline 37. Zro2 & $: 937.688753$ & $\mathrm{E}-6$ & 38. Сa3P2O8 & 1.295062 & E-3 \\
\hline 39. P2O5 & : & 0 & 40. $\mathrm{NaCl}$ & : & 0 \\
\hline NaF & : & 0 & 42. Na2SO4 & $: 165.094568$ & E-6 \\
\hline Sro & : & 0.0 & 44. Alpha & : 57.588305 & $E-6$ \\
\hline $\mathrm{HgO}$ & : & 0 & & & \\
\hline
\end{tabular}

SME : Output Mass Fractions

stream density : $\quad 11.199239$ (1bm/gal)

\begin{tabular}{|c|c|c|c|c|c|c|}
\hline 1. $\mathrm{H} 2 \mathrm{O}$ & \multicolumn{2}{|c|}{0.521369} & 2. $\mathrm{HCOOH}$ & : & 0.010 & 0194 \\
\hline 3. С6H6 & : & 0.0 & 4. NH3 & : & & -0.0 \\
\hline 5. $\mathrm{B}(\mathrm{OH}) 3$ & 2.873103 & $E-6$ & 6. $\mathrm{NaCO} 2 \mathrm{H}$ & : & & 0 \\
\hline 7. $\mathrm{KCO} 2 \mathrm{H}$ & 3.102217 & $E-6$ & 8. $\mathrm{CsCO} 2 \mathrm{H}$ & $:$ & & 0 \\
\hline 9. $\mathrm{NH} 4 \mathrm{CO} 2 \mathrm{H}$ & : & 0.0 & 10. CuN206 & $:$ & 1.160226 & $\mathbf{E}-6$ \\
\hline 11. NaTPB & : & 0 & 12. KTPB & $:$ & & 0.0 \\
\hline 13. CsTPB & : & 0 & 14. NH4TPB & : & & 0.0 \\
\hline 15. NaNO2 & : & 0.0 & 16. NaNO3 & : & & 0.0 \\
\hline 17. $\mathrm{NaOH}$ & 0.01 & 8243 & 18. NaTi2O5H & : & 0.025 & 5040 \\
\hline 19. HNO3 & 0.01 & 8405 & 20. Al203 & : & 0.016 & 6200 \\
\hline 21. B2O3 & 0.03 & 3382 & 22. $\mathrm{BaO}$ & : & & 0 \\
\hline $\mathrm{CaO}$ & 2.695475 & $E-3$ & 24. Cr2O3 & & 54.543261 & $E-6$ \\
\hline $\mathrm{Cs} 20$ & 157930 & $E-6$ & 26. CuO & & 67.040704 & $E-6$ \\
\hline $\mathrm{Fe} 203$ & 0.04 & 7382 & 28. K2O & : & 90.653723 & $E-6$ \\
\hline Li20 & : & 3912 & 30. $\mathrm{MgO}$ & : & $6.351 . L 55$ & $E-3$ \\
\hline
\end{tabular}



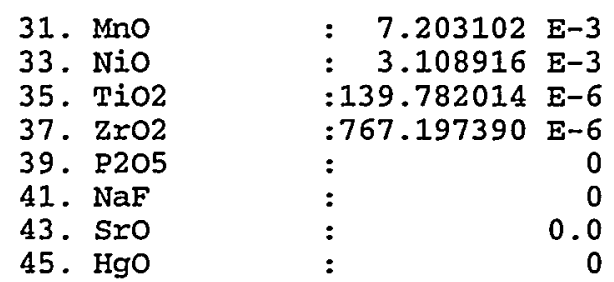

32. $\mathrm{Na} 2 \mathrm{O}$

34. SiO2

36. U308

38. Ca3P208

40. NaCl

42. $\mathrm{Na2SO} 4$

44. Alpha

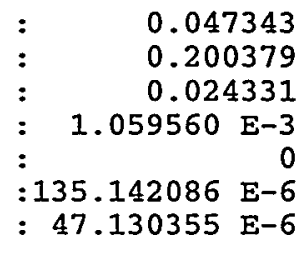

MFT : Output Mass Fractions stream density :

11.526848 ( Ibm/gal)

1. $\mathrm{H} 2 \mathrm{O}$
3. $\mathrm{C} 6 \mathrm{H} 6$
5. $\mathrm{B}(\mathrm{OH}) 3$
7. $\mathrm{KCO} 2 \mathrm{H}$
9. $\mathrm{NH} 4 \mathrm{CO} 2 \mathrm{H}$
11. NaTPB
13. $\mathrm{CsTPB}$
15. NaNO2
17. NaOH
19. $\mathrm{HNO}$
21. $\mathrm{B} 2 \mathrm{O} 3$
23. $\mathrm{CaO}$
25. $\mathrm{Cs} 2 \mathrm{O}$
27. $\mathrm{Fe} 2 \mathrm{O} 3$
29. Li2O
31. $\mathrm{MnO}$
33. NiO
35. TiO2
37. ZrO2
39. $\mathrm{P} 2 \mathrm{O} 5$
41. NaF
43. SrO
$45 . \mathrm{HgO}$

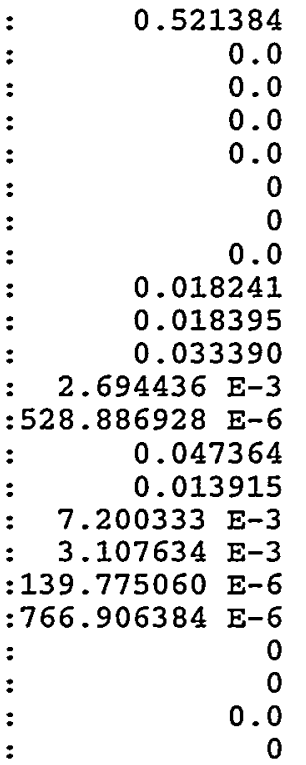

2. $\mathrm{HCOOH}$

4. $\mathrm{NH} 3$

6. $\mathrm{NaCO} 2 \mathrm{H}$

8. $\mathrm{CsCO} 2 \mathrm{H}$

10. CuN2O6

12. KTPB

14. NH4TPB

16. NaNO3

18. $\mathrm{NaTi} 2 \mathrm{O} 5 \mathrm{H}$

20. Al203

22. BaO

24. Cr2O3

26. Cuo

28. K2O

30. $\mathrm{MgO}$

32. $\mathrm{Na2O}$

34. SiO2

36. U308

38. Са3P2O8

40. $\mathrm{NaCl}$

42. $\mathrm{Na2SO} 4$

44. Alpha

\begin{tabular}{|c|c|c|}
\hline : & 0.010 & 0191 \\
\hline : & & -0.0 \\
\hline : & - & 0.0 \\
\hline : & & 0.0 \\
\hline : & & 0.0 \\
\hline : & & 0.0 \\
\hline : & & 0.0 \\
\hline : & & 0.0 \\
\hline : & 0.025 & 5036 \\
\hline : & 0.016 & 6193 \\
\hline : & & 0 \\
\hline & 54.378858 & $E-6$ \\
\hline & 66.973614 & $E-6$ \\
\hline : & 90.619659 & E-6 \\
\hline : & 6.352166 & $E-3$ \\
\hline : & 0.047 & 7345 \\
\hline : & 0.200 & 0420 \\
\hline : & 0.024 & 4325 \\
\hline : & 1.059193 & $E-3$ \\
\hline : & & \\
\hline & & \\
\hline & 00 & \\
\hline
\end{tabular}

MELTER Output Mass Fractions MELTER óutput density:

$22.055457 \mathrm{lbm} / \mathrm{gal}$

1. $\mathrm{H} 2 \mathrm{O}$
3. $\mathrm{B} 2 \mathrm{O} 3$
5. $\mathrm{CaO}$
7. $\mathrm{Cs} 2 \mathrm{O}$
9. $\mathrm{Fe} 2 \mathrm{O} 3$
11. $\mathrm{Li} 2 \mathrm{O}$
13. $\mathrm{MnO}$
15. $\mathrm{NiO}$
17. TiO2
19. ZrO2
21. $\mathrm{P} 2 \mathrm{O} 5$
23. NaF
25. SrO
27. $\mathrm{HgO}$

\begin{tabular}{|c|c|}
\hline & \\
\hline 0 & 2. Al2O3 \\
\hline 0.075243 & 4. $\mathrm{BaO}$ \\
\hline $6.072845 \mathrm{E}-3$ & 6. $\operatorname{Cr} 203$ \\
\hline $191861 E-3$ & 8. $\mathrm{CuO}$ \\
\hline 0.106752 & 10. K2O \\
\hline 0.031356 & 12. $\mathrm{MgO}$ \\
\hline 0.016228 & 14. Na2O \\
\hline $7.004129 \mathrm{E}-3$ & 16. SiO2 \\
\hline 0.045446 & 18. U308 \\
\hline $1.728489 \mathrm{E}-3$ & 20. Са3Р208 \\
\hline 0 & 22. $\mathrm{NaCl}$ \\
\hline 0 & 24. $\mathrm{Na} 2 \mathrm{SO} 4$ \\
\hline 0.0 & 26. Alpha \\
\hline 0 & \\
\hline
\end{tabular}

: $\quad 0.036498$ $: 1.024100 \mathrm{E}-3$ :376.333149 E-6 :204.243704 E-6 : $\quad 0.014315$ : $\quad 0.147302$ : $\quad 0.451636$ 0.054825 : $2.387258 \mathrm{E}-3$ :304.319791 E-6 :106.154963 E-6

Recycle Mass Fractions stream density : $8.408992(1 \mathrm{bm} / \mathrm{gal})$
1. $\mathrm{H} 2 \mathrm{O}$
3. $\mathrm{C} 6 \mathrm{H} 6$
5. Во3H 3
7. $\mathrm{KCO} 2 \mathrm{H}$
9. $\mathrm{NH} 4 \mathrm{CO} 2 \mathrm{H}$
0.973459
0.0

2. $\mathrm{CO} 2 \mathrm{H} 2$

4. NH3

6. $\mathrm{NaCO} 2 \mathrm{H}$

8. $\mathrm{CsCO} 2 \mathrm{H}$

10. CuN2O6

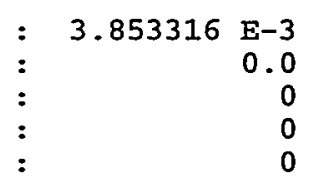


11. NaTPB

13. CsTPB

15. NaNO2

:

17. $\mathrm{NaOH}$

$\quad 3.033173 \mathrm{E}-3$
0.019654

0 12. KTPB

14. NH4TPB
16. NaNO3

0

0 


\section{CST NON-ELUTABLE ION EXCHANGE}

\subsection{Model Description}

The SPEEDUP model for the CST Non-Elutable Ion Exchange column describes the ion exchange loading of Cs onto the granular CST fixed bed as an adsorption process. The computational method applicable to an unsteady operation of a packed column provided by Bird et al..$^{7.1}$ is used. For simplicity, the method involves a number of assumptions:

1. The solution contains only two components, i.e. a solvent and a single solute.

2. No axial dispersion ${ }^{\dagger}$ or back-mixing of the fluid. The solution is passed at a constant volumetric flow rate through the packed column.

3. Solute concentration is uniform over any cross section.

4. Equilibrium is established between the solute concentration adsorbed on the solid and the local solute concentration in the solution.

5. Solute concentration in the solution is small, i.e. dilute solution, so that the operation may be considered isothermal.

6. The solid bed only adsorbs the solute from the solution. Hence, no competing adsorption occurs.

7. Resistance of the solid to mass transfer is negligible.

Material balances are set up in differential form for both the CST solid phase and the salt solution feed. In a section of column of length $d z$, the continuity relationships for the solute in each phase are given as follow.

For the solid:

$$
\begin{aligned}
& (1-\varepsilon) S d z \frac{\partial c_{A s}}{\partial t}=\left(k_{x} a\right)\left(x_{A}-x_{A 0}\right) S d z \\
& \text { where } \varepsilon \text { Volume fraction of column occupied by liquid } \\
& S: \quad \text { Cross sectional area of (empty) column } \\
& c_{A s}: \quad \text { Moles of adsorbed solute per unit volume of solid } \\
& \text { phase } \\
& x_{A}: \quad \text { Bulk mole fraction of solute in fluid phase } \\
& x_{A O} \text { : Interfacial mole fraction of solute in fluid phase, } \\
& \text { assumed to be in equilibrium with } c_{A s} \\
& k_{\mathrm{x}}: \quad \text { The fluid-phase mass transfer coefficient } \\
& \text { a: Interfacial area per unit volume of bed }
\end{aligned}
$$

For the fluid:

$$
\varepsilon S c \frac{\partial x_{A}}{\partial t}=-W_{B} \frac{\partial x_{A}}{\partial z}-S\left(k_{x} a\right)\left(x_{A}-x_{A O}\right)
$$

\footnotetext{
${ }^{\dagger}$ Neglecting axial dispersion proved to be a significant assumption in model development work completed after this project was done. The SPEEDUP column model was enhanced to include axial dispersion in an effort to understand differences between our results and those of outside contractors. When this term was included, the SPEEDUP model agreed closely with independent column calculations.
} 


\section{where $c: \quad$ Total molar concentration of the liquid \\ $W_{B}$ : Molar flow rate of solvent}

The mass transfer coefficient $\left(k_{x} a\right)$ is assumed constant and determined by data regression. Over a small range of concentration, and particularly for dilute solutions, the interphase equilibrium distribution is frequently described by the Freundlich equation:

$$
x_{A O}=k\left(c_{A s}\right)^{n}
$$

The form of the equation indicates that plotting the equilibrium solute concentration as ordinate against adsorbate content of the solid as abscissa on logarithmic coordinates will provide a straight line of slope $n$ and intercept $k$. However, deviation from linearity is to be expected at high solute concentrations. The SPEEDUP model for CST Ion Exchange column uses an empirical expression for non-linear isotherms:

$$
x_{A O}=a\left[E X P\left(b c_{A S}\right)-1\right]
$$

where parameters $a$ and $b$ are obtained by curve-fitting the non-linear isotherm equation to test data.

The two material balance equations shown above are subjected to the two conditions:

Boundary condition:

$$
\text { At } z=0 \quad x_{A}=x_{A I} \quad \text { (for all } t>0 \text { ) }
$$

Initial condition:

$$
\text { At } t=0 \quad c_{A s}=c^{*} \quad(\text { for all } z>0)
$$

In the first cycle, $c^{*}=0$. In subsequent cycles, $c^{*}$ is the value calculated at the end of the previous cycle.

Bird et al. ${ }^{(1)}$ provided the analytical solution to the linear isotherm problem. In the SPEEDUP CST model, the solution is obtained numerically. The column is divided into 500 sections of equal length. Numerical integration over time is carried out in each section to compute $x_{A}$ and $c_{A s}$.

Beck $^{(2)}$ solved the linear isotherm problem analytically using MATLAB for a $4 \mathrm{ft}$-diameter column. The three column lengths under consideration are $8 \mathrm{ft}, 16 \mathrm{ft}$, and $24 \mathrm{ft}$. Beck's results agree well with those obtained from SPEEDUP as illustrated in Figure 7.1 below. 
Figure 7.1: Comparison of Numerical and Analytical Solution

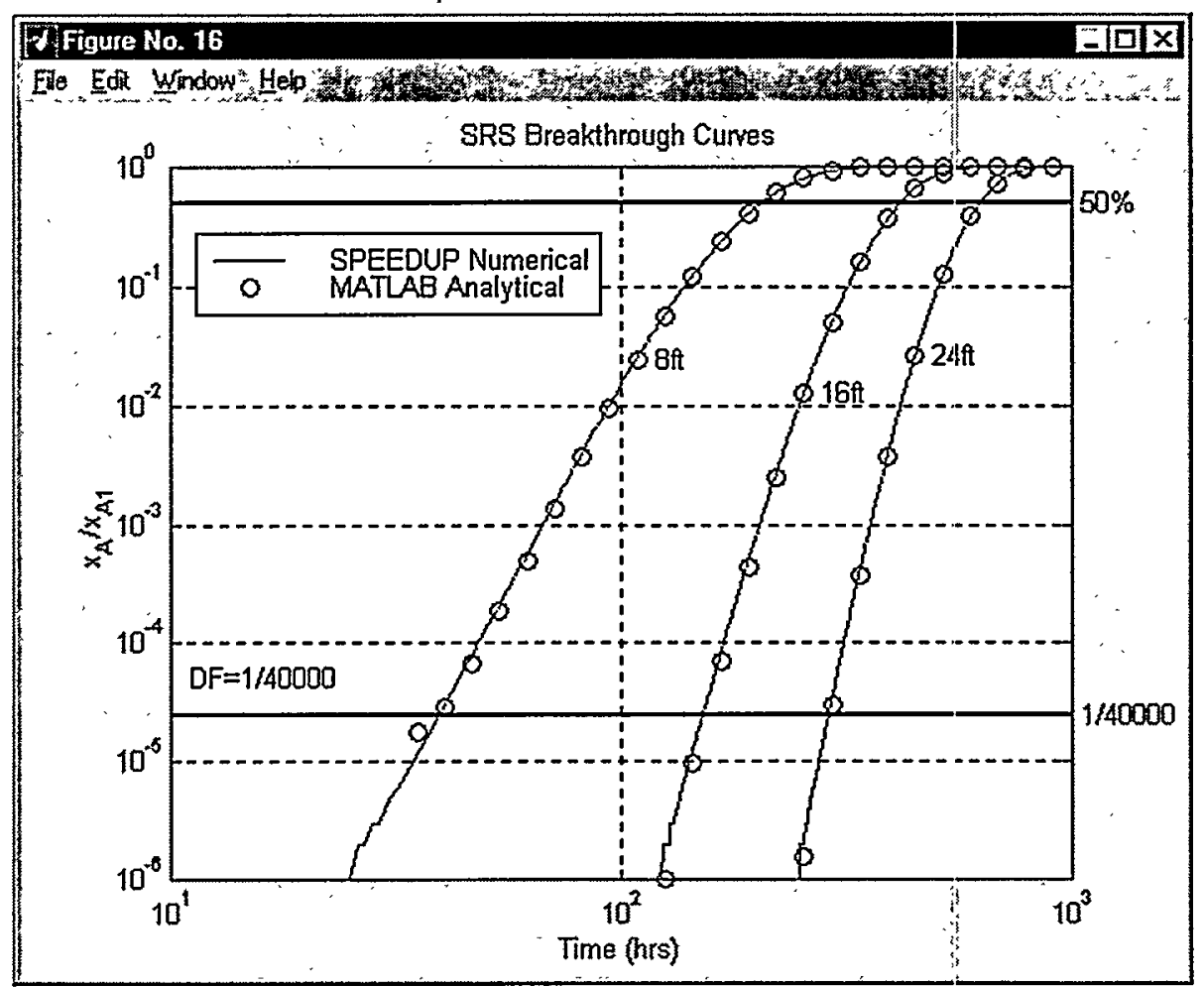

The impact of the non-linear isotherm on the breakthrough curve is a subject of interest. As previously discussed, deviation from linearity becomes more pronounced at high solute concentrations. In this concentration range, the Freundlich equation tends to overpredict the solute loading on the solid. Hence, the breakthrough curve is shifted to the left, resulting in a shorter cycle time. Figure 7.2 shows the breakthrough curves for a $4 \mathrm{ft}$ diameter and $8 \mathrm{ft}$ long CST IX column using three different interphase equilibrium equations for $x_{A O}$. The feed to the IX column is the SRS 5.6M salt solution. The linear isotherm $x_{A 0}=0.037695 c_{A s}$ clearly yields the shortest cycle time.

There are two reactions that occur in the IX bed. $\mathrm{Cs}^{+}$is exchanged for $\mathrm{Na}^{+}$which is to be included in the decontaminated salt solution. A small amount of $\mathrm{K}^{+}$exchanges onto the resin and goes with the CST to the DWPF. These reactions are ignored in the current SPEEDUP CST model because they are inconsequential to the material balance. 
Figure 7.2: Effect of Non-Linear Isotherms

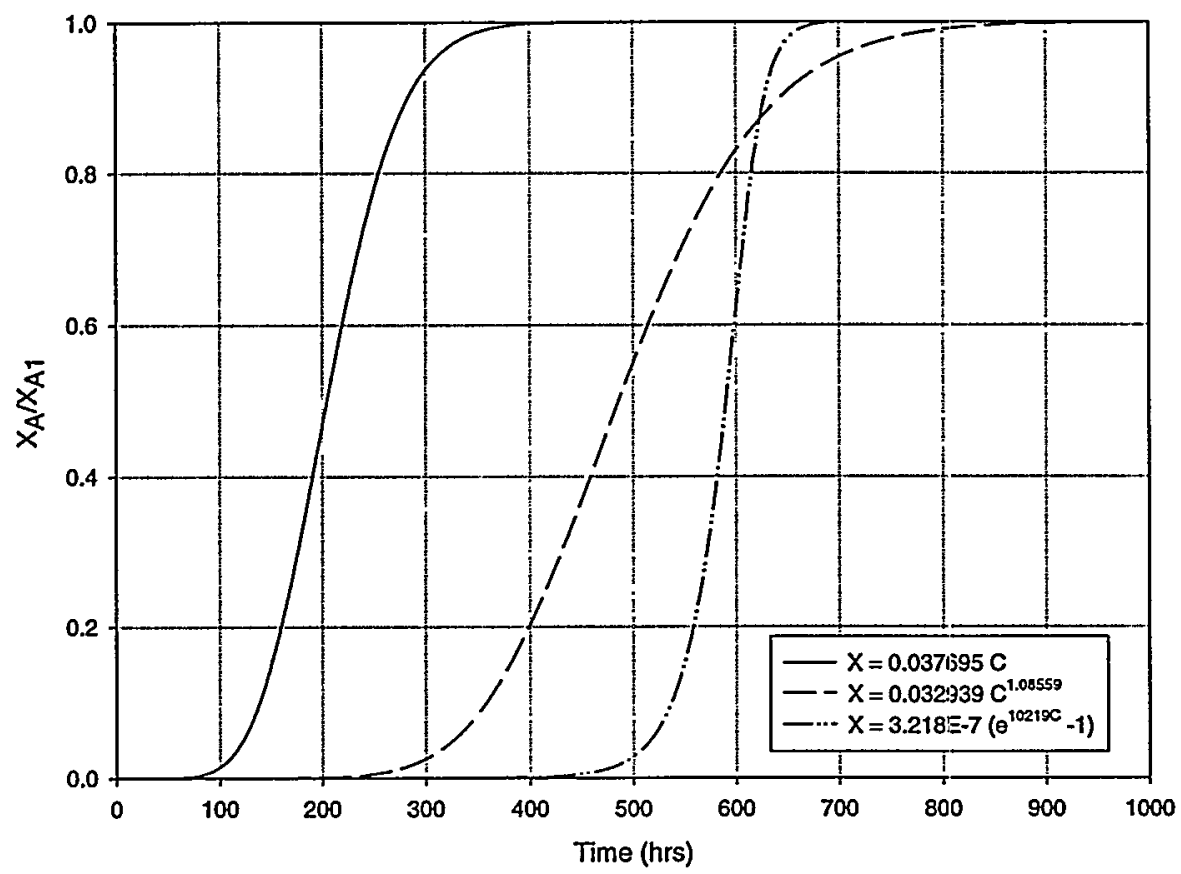

\subsection{CST IX SPEEDUP Flowsheet}

The CST IX process is schematically represented by the SPEEDUP flowsheet shown in Figure 3. The entire model consists of six units: feeder, IX1, IX2, IX3, decon_product, and cst_info. IX1, IX2 and IX3 are physical units representing the three CST IX columns. Feeder, CST_Info and Decon_Product are non-physical units used for information extraction and conversion of chemical component vector. A brief description of each unit is given below.

Figure 7.3: Schematic SPEEDUP Flow Diagram of the CST IX Process

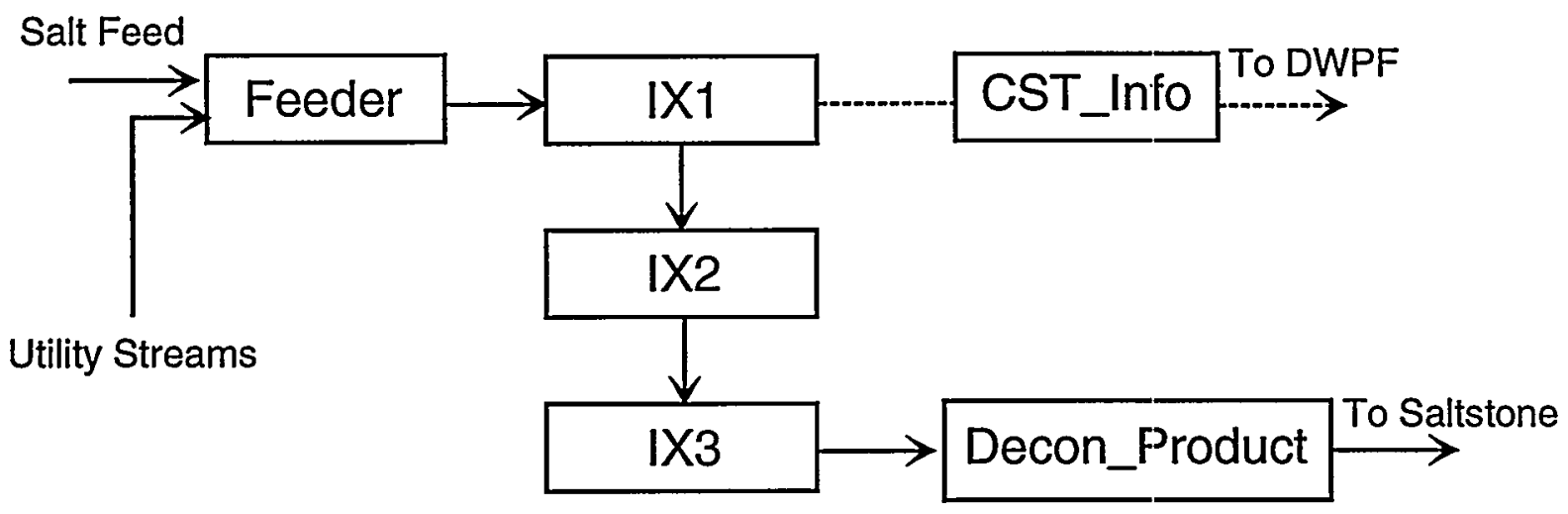




Unit
Feeder
IX1
the first CST IX column, and convert the 51.-component feed stream into
a 2-component stream.
Model the CST IX first (lead) column. IX1 is a macro consisting of
STAGE and MONTOR submodels. STAGE computes the material
balance in a section of column of length $d z$. MONITOR provides data at
the column outlet (i.e. $d f$, Cs mass concentration, and amount of Cs
adsorbed on CST bed)
Model the CST IX second (guard) column. Functions similar to IX1.
IX2
Model the CST IX third (standby) column. Functions similar to IX1.
Convert the 2-component product stream at the outlet of the third IX
column back to a 51-component decontaminated salt solution stream.
Pecon_Product
Provide information about the 10 Wt\% CST. slurry to be sent to DWPF.
The slurry results from treatment of the loaded CST resin in the lead
column rotated out of service at the end of a cycle. In addition to the
slurry information, cycle time and total Cs loading are also given.

The CST IX process is operated as follows ${ }^{1.2}$. The standard three-column carousel arrangement is assumed. This arrangement includes a lead column followed by a guard column to assure sufficient decontamination. The third column is maintained standby loaded with fresh resin. A cycle is completed when either of the following criteria is satisfied ${ }^{7.3}$ : (1) Molar concentration ratio $C / C_{o}$ for $C s$ at the exit of the lead column reaches 0.9 , (2) the Cs concentration in the liquid at the exit of the guard column reaches 1.3 micrograms $\mathrm{Cs} / \mathrm{L}$ (or $20 \mathrm{nCi} / \mathrm{g}$ ). At the end of the cycle, the loaded lead column is rotated out of service, the guard column becomes the lead column, and the standby column becomes the guard column. The resin is slurried from the loaded column, fresh resin is added, and this column then goes to standby.

The column changeover at the end of a cycle is simulated in SPEEDUP by utilizing the INITIAL subsection of the OPERATION section. To initialize each run, three variables are required in each column: Cs_mass (Cs amount loaded on CST resin), c_As (moles of Cs loading per unit volume of CST), and $x_{\text {_Cs }}$ (Cs mole fraction in the liquid phase). At the beginning of the first cycle, all three variables assume zero values. At the end of a cycle, the computed values of the three variables are captured for columns 2 and 3 . In the next cycle, the values in column 2 from the previous cycle are used for those in column 1, and the values in column 3 become those in column 2. The variables in column 3 are set to zero since the new standby column is loaded with fresh resin. The REPORT. OPERATION is used to capture the values of Cs_mass, c_As, and x_Cs at the end of a cycle and to create the new OPERATION section to be used in the next cycle.

\subsection{Case Analyses}

Two cases were run to determine the cycle time. Data required for each run are summarized below ${ }^{7.3}$ : 


\section{CASE 1: YEAR 2014}

Feed rate: $20.1 \mathrm{gal} / \mathrm{min}$

Nat: $\quad 5.60 \mathrm{M}$

Density: $\quad 10.224 \mathrm{lbs} / \mathrm{gal}$

Mass fraction:

$\begin{array}{ll}\mathrm{H} 2 \mathrm{O} & 0.7009329 \\ \mathrm{NaNO} 3 & 0.1631604 \\ \mathrm{NaOH} & 0.0551148 \\ \mathrm{KOH} & 0.0008087 \\ \mathrm{Na} 2 \mathrm{CO} 3 & 0.0158003 \\ \text { misc Na salts } & 0.0058082 \\ \mathrm{NaNO} 2 & 0.0197163 \\ \mathrm{KNO} 3 & 0.0000039 \\ \mathrm{NaAlO} 2 & 0.0166773 \\ \mathrm{CsOH} & 0.0000257 \\ \mathrm{Na} 2 \mathrm{SO} 4 & 0.0214227 \\ \mathrm{HgO} & 0.0000185\end{array}$

Isotherm:

\begin{tabular}{c|c}
$\begin{array}{c}\mathbf{C} \\
\text { mol frac }\end{array}$ & $\begin{array}{c}\mathbf{Q}^{*} \\
\mathrm{~mol} / \mathrm{cm} 3\end{array}$ \\
\hline $1.767 \mathrm{E}-06$ & $9.996 \mathrm{E}-05$ \\
$8.522 \mathrm{E}-07$ & $5.688 \mathrm{E}-05$ \\
$2.545 \mathrm{E}-07$ & $1.928 \mathrm{E}-05$ \\
$4.980 \mathrm{E}-08$ & $3.933 \mathrm{E}-06$ \\
$9.886 \mathrm{E}-09$ & $7.914 \mathrm{E}-07$ \\
$9.886 \mathrm{E}-10$ & $7.914 \mathrm{E}-08$ \\
$9.886 \mathrm{E}-11$ & $7.914 \mathrm{E}-09$ \\
9.886E-12 & $7.914 \mathrm{E}-10$ \\
*: includes CST dilution factor $=0.7$
\end{tabular}




\section{CASE 2: YEAR 2016}

Feed rate: $\quad 20.1 \mathrm{gal} / \mathrm{min}$

$\mathrm{Na}+\mathrm{N} \quad \quad 5.60 \mathrm{M}$

Density: $\quad 10.410 \mathrm{lbs} / \mathrm{gal}$

Mass fraction:

$\begin{array}{ll}\mathrm{H} 2 \mathrm{O} & 0.7009329 \\ \mathrm{NaNO} 3 & 0.1631604 \\ \mathrm{NaOH} & 0.0551148 \\ \mathrm{KOH} & 0.0008087 \\ \mathrm{Na} 2 \mathrm{CO} 3 & 0.0158003 \\ \text { misc Na salts } & 0.0058082 \\ \mathrm{NaNO} 2 & 0.0197163 \\ \mathrm{KNO} 3 & 0.0000039 \\ \mathrm{NaAlO} 2 & 0.0166773 \\ \mathrm{CsOH} & 0.0000257 \\ \mathrm{Na} 2 \mathrm{SO} 4 & 0.0214227 \\ \mathrm{HgO} & 0.0000185\end{array}$

Isotherm:

\begin{tabular}{r|c}
$\begin{array}{c}C \\
\text { mol frac }\end{array}$ & $\begin{array}{c}\mathbf{Q}^{*} \\
\text { mol/cm3 }\end{array}$ \\
\hline $4.795 \mathrm{E}-06$ & $1.690 \mathrm{E}-04$ \\
$2.286 \mathrm{E}-06$ & $1.083 \mathrm{E}-04$ \\
$6.653 \mathrm{E}-07$ & $4.064 \mathrm{E}-05$ \\
$1.267 \mathrm{E}-07$ & $8.568 \mathrm{E}-06$ \\
$2.695 \mathrm{E}-08$ & $1.850 \mathrm{E}-06$ \\
$4.460 \mathrm{E}-09$ & $3.088 \mathrm{E}-07$ \\
$4.460 \mathrm{E}-10$ & $3.088 \mathrm{E}-08$ \\
$4.460 \mathrm{E}-11$ & $3.088 \mathrm{E}-09$ \\
*: includes CST dilution factor $=0.7$
\end{tabular}

\subsection{Results}

The REPORT SUMMARY captures the specified and computed data to provide the following outputs:

1. The salt solution feed stream.

2. Utility streams (water and $\mathrm{NaOH}$ ).

3. Decontaminated salt solution.

4. CST slurry stream.

5. CST cycle time.

6. Loading of Cs on CST (mg Cs/g CST) in the CST slurry.

7. Profile of Cs concentration in the liquid phase along the entire length of the three columns.

In both cases, the results show that $C s$ is totally removed within the first two columns. No Cs reaches the third column. All cycles are completed because the first requirement (i.e. $C / C_{o}$ for $C s$ at the exit of the 
lead column $=0.9$ ) is satisfied. Due to the fresh resin loaded in the lead column at the start of the operation, the cycle time is longer in the first cycle, then approaches a stable value in subsequent cycles. The cycle time is about 960 hours for Case 1, and about 650 hours for Case 2.

The complete results of the analysis are shown below in Figures 4, 5, 6 for Case 1 and in Figures 7, 8, 9 for Case 2.

It should be noted that a constant fluid-phase mass transfer coefficient per unit volume of bed $k_{x} a$ (i.e. $1.7694 \times 10^{6} \mathrm{moles} / \mathrm{hr}-\mathrm{m}^{3}$ ) was used in these runs. The impact of $k_{x} a$ on the cycle time was studied for Case $1 /$ Cycle 1 . The analysis is summarized in the Table below.

\begin{tabular}{|c|c|c|c|}
\hline $\begin{array}{c}k_{x} a \\
\left(m o l e s / h r-m^{3}\right)\end{array}$ & $\begin{array}{c}\text { Cycle Time } \\
(\mathrm{hr})\end{array}$ & $\begin{array}{c}\text { Cycle Completion due } \\
\text { to Criterion } 1^{(\mathrm{a})}\end{array}$ & $\begin{array}{c}\text { Cycle Completion due } \\
\text { to Criterion } 2^{(\mathbf{b})}\end{array}$ \\
\hline $1 \mathrm{E} 4$ & 1.4 & & $\mathrm{X}$ \\
\hline $5 \mathrm{E} 5$ & 854 & & $\mathrm{X}$ \\
\hline $7 \mathrm{E} 5$ & 1085 & $\mathrm{X}$ & $\mathrm{X}$ \\
\hline $8 \mathrm{E} 5$ & 1130 & $\mathrm{X}$ & \\
\hline $9 \mathrm{E} 5$ & 1114 & $\mathrm{X}$ & \\
\hline $1 \mathrm{E} 6$ & 1101 & $\mathrm{X}$ & \\
\hline $1.7694 \mathrm{E} 6$ & 1047 & $\mathrm{X}$ & \\
\hline $2 \mathrm{E} 6$ & 1039 & $\mathrm{X}$ & \\
\hline $4 \mathrm{E} 6$ & 1006 & $\mathrm{X}$ & \\
\hline $1 \mathrm{E} 7$ & 986 & $\mathrm{X}$ & \\
\hline $1 \mathrm{E} 8$ & 974 & & \\
\hline
\end{tabular}

(a) Molar concentration ratio $\mathrm{C} / \mathrm{C}_{\mathrm{o}}$ for $\mathrm{Cs}$ at the exit of the lead column reaches 0.9

(b) $\mathrm{Cs}$ concentration in the liquid at the exit of the guard column reaches 1.3 micrograms $\mathrm{Cs} / \mathrm{L}$

The cycle time peaks around a $k_{x} a$ value of $8 \mathrm{E} 5$. The analysis shows that at low $k_{x} a$ more Cs is sent from the lead column to the guard column due to the slow adsorption process. Hence, in the low $k_{x} a$ range the cycle is completed due to the second criterion. Increasing $k_{x} a$ would result in better Cs adsorption, causing a more rapid saturation of the CST resin in the lead column, thus satisfying the first criterion to complete the cycle. 
Figure 7.4: Result of Case 1/ Cycle 1

CASE :

Cycle Number:

Cycle Time (hrs):
YR2014

CYCLE1

1047.82878

Salt Feed Stream

20.10000

10.22400

Density (1b/gal):

Mass fraction:

\begin{tabular}{|c|c|c|}
\hline & & \\
\hline 0.71673 & 1. & $\mathrm{H} 2 \mathrm{O}$ \\
\hline $0.60425 \mathrm{E}-2$ & 2. & Misc. salts \\
\hline 0.12387 & 3. & NaNO3 \\
\hline $0.37657 \mathrm{E}-1$ & 4. & NaNO2 \\
\hline $0.74640 \mathrm{E}-1$ & 5. & $\mathrm{NaOH}$ \\
\hline 0 & 6. & KNO3 \\
\hline 0 & 7. & CsNO3 \\
\hline & 8. & NH4NO3 \\
\hline 0 & 9. & $\mathrm{NH} 4 \mathrm{OH}$ \\
\hline $0.16662 \mathrm{E}-1$ & 10 . & $\mathrm{NaALO} 2$ \\
\hline 0 & 11. & Misc. sludge \\
\hline 0 & 12 . & $\mathrm{Na} 2 \mathrm{U} 2 \mathrm{O} 7$ \\
\hline 0 & 13. & $\mathrm{Fe}(\mathrm{OH}) 3$ \\
\hline 0 & 14. & $\mathrm{Al}(\mathrm{OH}) 3$ \\
\hline 0 & 15 . & $\mathrm{Cr}(\mathrm{OH}) 2$ \\
\hline 0 & 16. & $\mathrm{C} 6 \mathrm{H} 6$ \\
\hline 0 & 17. & Phenol/Phenoxide \\
\hline $0.11400 \mathrm{E}-4$ & 18 & $\mathrm{CsOH}$ \\
\hline $0.85430 \mathrm{E}-3$ & 19 . & $\mathrm{KOH}$ \\
\hline 0 & 20 . & $\mathrm{CsB}(\mathrm{C} 6 \mathrm{H} 54$ \\
\hline 0 & 21. & $\operatorname{NaB}(\mathrm{C} 6 \mathrm{H} 5) 4$ \\
\hline 0 & 22 . & $\mathrm{Na} 2(\mathrm{C} 6 \mathrm{H} 5) \mathrm{BO} 2$ \\
\hline 0 & 23 . & $\mathrm{KB}(\mathrm{C} 6 \mathrm{H} 5) 4$ \\
\hline 0 & 24 . & NH4B (C6H5) 4 \\
\hline 0 & 25 . & NaTi205H \\
\hline 0 & 26 . & NaT.S (OH) 2 \\
\hline
\end{tabular}

\begin{tabular}{|c|c|c|}
\hline 0 & 27. & $\mathrm{NaT} . \mathrm{Na} 2 \mathrm{U} 2 \mathrm{O} 7$ \\
\hline 0 & 28. & (C6H5) 3B \\
\hline 0 & 29. & (C6H5) $2 \mathrm{BOH}$ \\
\hline 0 & 30. & (C6H5) B (OH) 2 \\
\hline 0 & 31. & $\mathrm{~B}(\mathrm{OH}) 3$ \\
\hline 0 & $32:$ & $\mathrm{K} 2 \mathrm{O}$ \\
\hline 0 & 33. & LiO2 \\
\hline 0 & 34. & MO \\
\hline 0 & 35. & Mno \\
\hline 0 & 36. & TiO2 \\
\hline 0 & 37. & U308 \\
\hline 0 & 38. & $\mathrm{ZrO} 2$ \\
\hline 0 & 39. & Са3Р2O8 \\
\hline 0 & 40. & P205 \\
\hline 0 & 41 . & Cr20 \\
\hline 0 & 42 . & $\mathrm{CsO} 2$ \\
\hline 0 & 43. & CuO \\
\hline 0 & 44. & $\mathrm{Na} 2 \mathrm{O}$ \\
\hline 0 & 45 . & $\mathrm{NiO}$ \\
\hline 0 & 46. & $\mathrm{SiO} 2$ \\
\hline $0.30300 \mathrm{E}-4$ & 47 . & HgO \\
\hline 0 & 48. & alpha (PuO2) \\
\hline 0 & 49. & $\mathrm{CaCO} 3$ \\
\hline $0.10826 \mathrm{E}-1$ & 50. & $\mathrm{Na} 2 \mathrm{CO} 3$ \\
\hline $0.12679 \mathrm{E}-1$ & 51. & $\mathrm{Na} 2 \mathrm{SO}_{4}$ \\
\hline
\end{tabular}

\begin{tabular}{ll} 
& \multicolumn{1}{c}{ Additions to Salt Feed Stream } \\
\cline { 2 - 2 } Inventory water (1bs) : & 47000. \\
2M NaOH solution (lbs): & 23500. \\
Excess water to slurry resin (Ibs): & 25850.
\end{tabular}

Decontaminated Salt Solution

Flow rate (gpm):

Density (lb/gal):

Mass fraction:

$\begin{array}{lll}0.73319 & 1 . & \text { H2O } \\ 0.56659 \mathrm{E}-2 & 2 . & \text { Misc. salts } \\ 0.11615 & \text { 3. } & \text { NaNO3 } \\ 0.35310 \mathrm{E}-1 & \text { 4. } & \text { NaNO2 } \\ 0.71196 \mathrm{E}-1 & 5 . & \text { NaOH } \\ 0 & \text { 6. } & \text { KNO3 } \\ 0 & 7 . & \text { CsNO3 } \\ 0 & \text { 8. } & \text { NH4NO3 } \\ 0 & 9 . & \text { NH4OH } \\ 0.15624 \mathrm{E}-1 & 10 . & \text { NaALO2 }\end{array}$

21.71673

10.09703

$\begin{array}{ll}0 & \text { 11. Misc. sludge } \\ 0 & 12 . \mathrm{Na} 2 \mathrm{U} 2 \mathrm{O} 7 \\ 0 & 13 . \mathrm{Fe}(\mathrm{OH}) 3 \\ 0 & 14 . \mathrm{Al}(\mathrm{OH}) 3 \\ 0 & 15 . \mathrm{Cr}(\mathrm{OH}) 2 \\ 0 & 16 . \mathrm{C} 6 \mathrm{H} 6 \\ 0 & 17 . \mathrm{Phenol} / \text { Phenoxide } \\ 0 & 18 . \mathrm{CsOH} \\ 0.80105 \mathrm{E}-3 & 19 . \mathrm{KOH} \\ 0 & 20 . \mathrm{CsB}(\mathrm{C} 6 \mathrm{H} 5) 4\end{array}$




\begin{tabular}{|c|c|c|c|}
\hline 0 & 21. $\mathrm{NaB}(\mathrm{C} 6 \mathrm{H} 5) 4$ & 0 & 37. U308 \\
\hline 0 & 22. $\mathrm{Na} 2(\mathrm{C} 6 \mathrm{H} 5) \mathrm{BO} 2$ & 0 & 38. $\mathrm{ZrO} 2$ \\
\hline 0 & 23. $\mathrm{KB}(\mathrm{C} 6 \mathrm{H} 5) 4$ & 0 & 39. Сa3P208 \\
\hline 0 & 24. NH4B (C6H5) 4 & 0 & 40. P2O5 \\
\hline 0 & 25. $\mathrm{NaTi} 205 \mathrm{H}$ & 0 & 41. Cr203 \\
\hline 0 & 26. NaT.S $(\mathrm{OH}) 2$ & 0 & 42. $\mathrm{CsO} 2$ \\
\hline 0 & 27. NaT.Na2U2O7 & 0 & 43. CuO \\
\hline 0 & 28. $(\mathrm{C} 6 \mathrm{H} 5) 3 \mathrm{~B}$ & 0 & 44. $\mathrm{Na} 2 \mathrm{O}$ \\
\hline 0 & 29. ( $(\mathrm{C} 6 \mathrm{H} 5) 2 \mathrm{BOH}$ & 0 & 45. NiO \\
\hline 0 & 30. ( $(\mathrm{CH} 5)$ В $(\mathrm{OH}) 2$ & 0 & 46. SiO2 \\
\hline 0 & 31. $B(\mathrm{OH}) 3$ & $0.28411 \mathrm{E}-4$ & 47. $\mathrm{HgO}$ \\
\hline 0 & 32. K2O & 0 & 48. alpha (PuO2) \\
\hline 0 & 33. LiO2 & 0 & 49. $\mathrm{CaCO} 3$ \\
\hline 0 & 34. MO & $0.10151 \mathrm{E}-1$ & $50 . \mathrm{Na} 2 \mathrm{CO} 3$ \\
\hline 0 & 35. MnO & $0.11889 E-1$ & 51. Na2SO4 \\
\hline 0 & 36. TiO2 & & \\
\hline
\end{tabular}

CST (1bs):

Cs (Ibs):

Water (1bs):
CST Slurry Stream per Cycle

19610.75000

120.32198

176496.75000

Loading of Cs on CST (mg Cs/g CST): $\quad 6.13551$

Cs Concentration (mol/L) in the Salt Solution along columns (Values given at equal distance between inlet and outlet)

\begin{tabular}{|c|c|c|c|}
\hline & Column 1 & Column 2 & Column 3 \\
\hline & $0.86280 \mathrm{E}-4$ & $0.77647 \mathrm{E}-4$ & 0.0 \\
\hline & $0.86274 \mathrm{E}-4$ & $0.31551 \mathrm{E}-4$ & 0.0 \\
\hline & $0.86274 \mathrm{E}-4$ & $0.44923 \mathrm{E}-5$ & 0.0 \\
\hline & $0.86274 \mathrm{E}-4$ & $0.49164 \mathrm{E}-6$ & 0.0 \\
\hline & $0.86274 \mathrm{E}-4$ & $0.51151 \mathrm{E}-7$ & 0.0 \\
\hline & $0.86274 \mathrm{E}-4$ & $0.51516 \mathrm{E}-8$ & 0.0 \\
\hline & $0.86274 \mathrm{E}-4$ & $0.49959 \mathrm{E}-9$ & 0.0 \\
\hline & $0.86274 \mathrm{E}-4$ & 0.0 & 0.0 \\
\hline & $0.86257 \mathrm{E}-4$ & 0.0 & 0.0 \\
\hline & $0.85831 \mathrm{E}-4$ & 0.0 & 0.0 \\
\hline & $0.77647 \mathrm{E}-4$ & 0.0 & 0.0 \\
\hline
\end{tabular}


Figure 7.5: Result of Case 1/ Cycle 2

CASE :

Cycle Number:

Cycle Time (hrs):
YR2014

CYCLE2

963.35126

\section{Salt Feed Stream}

Flow rate (gpm):

Density (1b/gal):

Mass fraction

$0.71673 \quad 1$. $\mathrm{H} 2 \mathrm{O} \quad 0$

$0.60425 \mathrm{E}-2$ 2. Misc. salts

3. NaNO3

0.12387

$0.37657 \mathrm{E}-1$

$0.74640 \mathrm{E}-1$

0

0

0

$0.16662 \mathrm{E}-1$

0

0

0

0

0

0

0

$0.11400 \mathrm{E}-4$

$0.85430 \mathrm{E}-3$

0

0

0

0

0

0

0

4. $\mathrm{NaNO} 2$

5. $\mathrm{NaOH}$

6. KNO3

7. CsNO3

8. $\mathrm{NH} 4 \mathrm{NO} 3$

9. $\mathrm{NH} 4 \mathrm{OH}$

10. NaALO2

11. Misc. sludge

20.10000

10.22400

12. $\mathrm{Na} 2 \mathrm{U} 2 \mathrm{O} 7$

13. $\mathrm{Fe}(\mathrm{OH}) 3$

14. Al $(\mathrm{OH}) 3$

15. $\mathrm{Cr}(\mathrm{OH}) 2$

16. С6H6

17. Phenol/Phenoxide

0

0

18. $\mathrm{CsOH}$

19. $\mathrm{KOH}$

20. $\mathrm{CsB}(\mathrm{C} 6 \mathrm{H} 54$

21. $\mathrm{NaB}(\mathrm{C} 6 \mathrm{H} 5) 4$

22. $\mathrm{Na} 2(\mathrm{C} 6 \mathrm{H} 5) \mathrm{BO} 2$

23. $\mathrm{KB}(\mathrm{C} 6 \mathrm{H} 5) 4$

24. NH4B (C6H5) 4

25. $\mathrm{NaTi} 205 \mathrm{H}$

26. $\mathrm{NaT} . \mathrm{S}(\mathrm{OH}) 2$

(a)

27. NaT.Na2U2O7

28. (C6H5) $3 \mathrm{~B}$

29. (C6H5) $2 \mathrm{BOH}$

30. $(\mathrm{C} 6 \mathrm{H} 5) \mathrm{B}(\mathrm{OH}) 2$

31. $\mathrm{B}(\mathrm{OH}) 3$

32. K2O

33. LiO2

34. MO

35. $\mathrm{MnO}$

36. TiO2

37. U308

38. $\mathrm{ZrO} 2$

39. Сa3P2O8

40. P2O5

41. Cr2O

42. $\mathrm{CsO} 2$

43. CuO

44. $\mathrm{Na} 2 \mathrm{O}$

45. NiO

46. SiO2

47. $\mathrm{HgO}$

48. alpha (PuO2)

49. $\mathrm{CaCO} 3$

50. $\mathrm{Na} 2 \mathrm{CO} 3$

51. $\mathrm{Na} 2 \mathrm{SO} 4$

$0.30300 \mathrm{E}-4$

0

$0.10826 \mathrm{E}-1$

$0.12679 \mathrm{E}-1$ $\frac{\text { Additions to Salt Feed Stream }}{47000}$ 23500 .

Inventory water (lbs): 2M NaOH solution (lbs): Excess water to slurry resin (1bs): 25850 .

\begin{tabular}{|c|c|c|c|}
\hline \multicolumn{4}{|c|}{$\begin{array}{l}\text { Flow rate }(\mathrm{gpm}): \\
\text { Density }(1 \mathrm{~b} / \mathrm{gal}) \text { : } \\
\text { Mass fraction: }\end{array}$} \\
\hline 0.73400 & 1. & $\mathrm{H} 2 \mathrm{O}$ & \\
\hline $0.56474 \mathrm{E}-2$ & 2 & Misc. & salts \\
\hline 0.11577 & 3. & NaNO3 & \\
\hline $0.35195 \mathrm{E}-1$ & 4. & NaNO2 & \\
\hline $0.71026 \mathrm{E}-1$ & 5 & $\mathrm{NaOH}$ & \\
\hline 0 & 6. & KNO3 & \\
\hline 0 & 7. & CsNO3 & \\
\hline 0 & 8. & NH4NO3 & \\
\hline 0 & 9. & $\mathrm{NH} 4 \mathrm{OH}$ & \\
\hline $0.15572 \mathrm{E}-1$ & 10. & $\mathrm{NaALO} 2$ & \\
\hline & 11. & Misc. & sludg \\
\hline
\end{tabular}

ted salt solution

21.80129

10.09087
12. $\mathrm{Na2U} 2 \mathrm{O} 7$

13. $\mathrm{Fe}(\mathrm{OH}) 3$

14. $\mathrm{Al}(\mathrm{OH}) 3$

15. $\mathrm{Cr}(\mathrm{OH}) 2$

16. $\mathrm{C} 6 \mathrm{H} 6$

17. Phenol/Phenoxide

18. $\mathrm{CsOH}$

19. $\mathrm{KOH}$

20. $\mathrm{CsB}(\mathrm{C} 6 \mathrm{H} 5) 4$

21. $\mathrm{NaB}(\mathrm{C} 6 \mathrm{H} 5) 4$

22. $\mathrm{Na} 2(\mathrm{C} 6 \mathrm{H} 5) \mathrm{BO} 2$ 


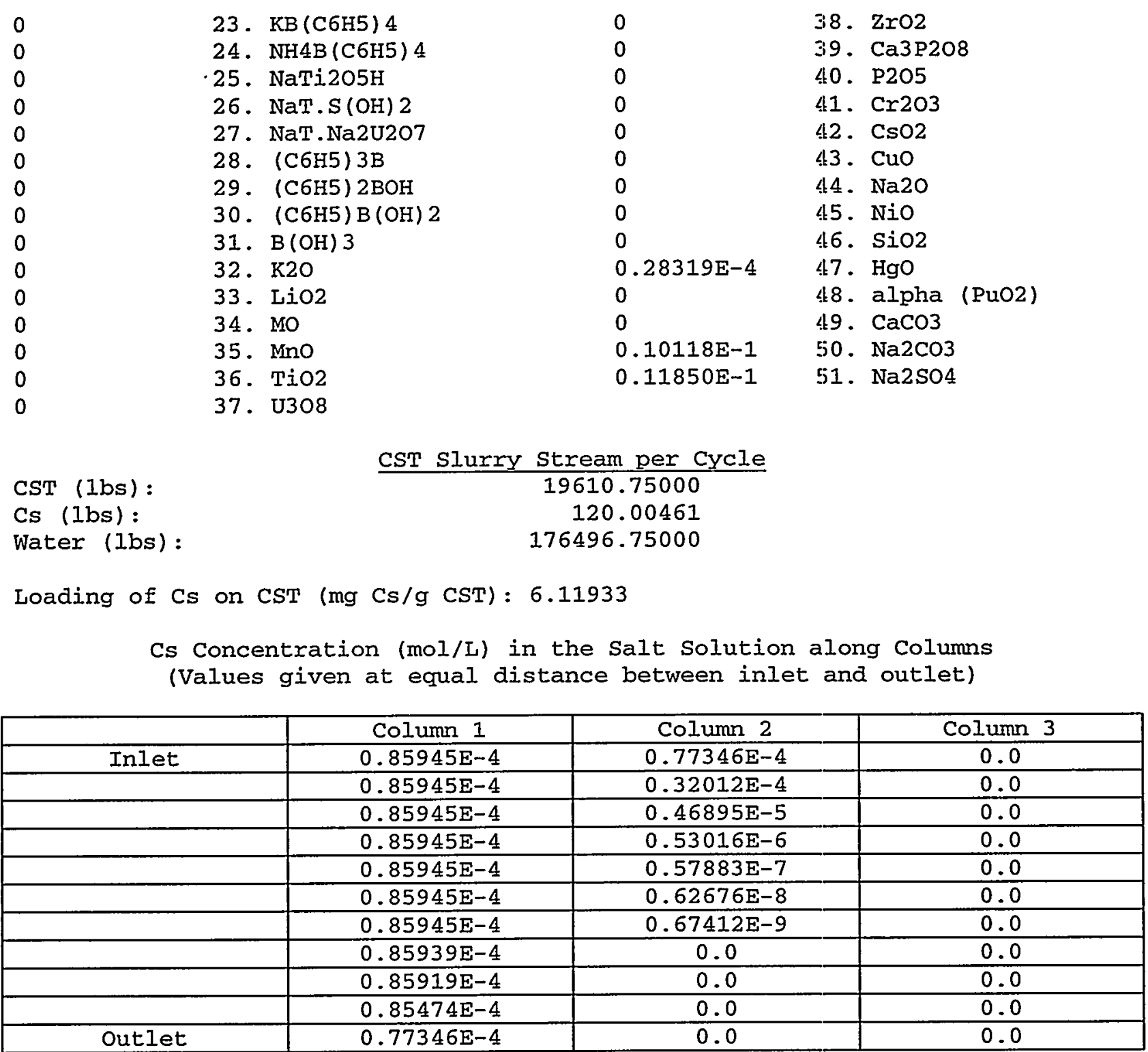


Figure 7.6: Result of Case 1/ Cycle 3

CASE :

Cycle Number:

Cycle Time (hrs):
YR2014

CYCLE3

962.55264

Salt Feed Stream

Flow rate (gpm): 20.10000

10.22400
27. NaT.Na2U2O7

28. (C6H5) 3B

29. (C6H5) $2 \mathrm{BOH}$

30. (C6H5) В $(\mathrm{OH}) 2$

31. $\mathrm{B}(\mathrm{OH}) 3$

32. $\mathrm{K} 2 \mathrm{O}$

33. LiO2

34. MO

35. MnO

36. TiO2

37. U308

38. $\mathrm{ZrO} 2$

39. Сa3 208

40. $\mathrm{P} 205$

41. Cr203

42. $\mathrm{CsO} 2$

43. CuO

44. $\mathrm{Na} 2 \mathrm{O}$

45. NiO

46. $\mathrm{SiO} 2$

47. HgO

48. alpha (PuO2)

49. $\mathrm{CaCO} 3$

50. $\mathrm{Na} 2 \mathrm{CO} 3$

51. $\mathrm{Na} 2 \mathrm{SO} 4$

25. NaTi2O5H

26. NaT.S(OH) 2

$0.10826 \mathrm{E}-1$

$0.12679 \mathrm{E}-1$

\section{Additions to Salt Feed stream}

Inventory water (lbs):
2M NaOH solution (lbs):
Excess water to slurry resin
Flow rate (gpm):
Density (lb/ga1):
$\begin{array}{ll}\text { Mass fraction: } \\ 0.73400 & \text { 1. H2O } \\ 0.56474 \mathrm{E}-2 & \text { 2. Misc. salts } \\ 0.11577 & \text { 3. NaNO3 } \\ 0.35195 \mathrm{E}-1 & \text { 4. NaNO2 } \\ 0.71026 \mathrm{E}-1 & \text { 5. NaOH } \\ 0 & \text { 6. KNO3 } \\ 0 & \text { 7. CsNO3 } \\ 0 & \text { 8. NH4NO3 } \\ 0 & 9 . \text { NH4OH }\end{array}$

47000 . 23500 . : 25850 .

Decontaminated salt Solution

$$
21.80129
$$

10.09087

$0.15572 \mathrm{E}-1$
0
0
0
0
0
0
0
0

10. NaALO2

11. Misc. sludge

12. $\mathrm{Na2U} 2 \mathrm{O} 7$

13. $\mathrm{Fe}(\mathrm{OH}) 3$

14. Al $(\mathrm{OH}) 3$

15. $\mathrm{Cr}(\mathrm{OH}) 2$

16. $\mathrm{C} 6 \mathrm{H} 6$

17. Phenol/Phenoxide

18. $\mathrm{CsOH}$ 


\begin{tabular}{|c|c|c|c|}
\hline $0.79843 E-3$ & 19. $\mathrm{KOH}$ & 0 & 36. TiO2 \\
\hline 0 & 20. $\operatorname{CsB}(\mathrm{C} 6 \mathrm{H} 5) 4$ & 0 & 37. U308 \\
\hline 0 & 21. $\mathrm{NaB}(\mathrm{C} 6 \mathrm{H} 5) 4$ & 0 & 38. ZrO2 \\
\hline 0 & 22. $\mathrm{Na} 2(\mathrm{C} 6 \mathrm{H} 5) \mathrm{BO} 2$ & 0 & 39. Са3Р208 \\
\hline 0 & 23. $\mathrm{KB}(\mathrm{C} 6 \mathrm{H} 5) 4$ & 0 & 40. P2O5 \\
\hline 0 & 24. NH4B (C6H5) 4 & 0 & 41. Cr2O3 \\
\hline 0 & 25. NaTi2O5H & 0 & 42. $\mathrm{CsO} 2$ \\
\hline 0 & 26. NaT.S $(\mathrm{OH}) 2$ & 0 & 43. CuO \\
\hline 0 & 27. NaT.Na2U2O7 & 0 & 44. $\mathrm{Na} 2 \mathrm{O}$ \\
\hline 0 & 28. $(\mathrm{C} 6 \mathrm{H} 5) 3 \mathrm{~B}$ & 0 & 45. NiO \\
\hline 0 & 29. $(\mathrm{C} 6 \mathrm{H} 5) 2 \mathrm{BOH}$ & 0 & 46. SiO2 \\
\hline 0 & 30. $(\mathrm{C} 6 \mathrm{H} 5) \mathrm{B}(\mathrm{OH}) 2$ & $0.28319 \mathrm{E}-4$ & 47. $\mathrm{HgO}$ \\
\hline 0 & 31. $\mathrm{B}(\mathrm{OH}) 3$ & 0 & 48. alpha (PuO2) \\
\hline 0 & 32. K2O & 0 & 49. $\mathrm{CaCO} 3$ \\
\hline 0 & 33. LiO2 & $0.10118 \mathrm{E}-1$ & 50. $\mathrm{Na} 2 \mathrm{CO} 3$ \\
\hline 0 & 34. MO & $0.11850 \mathrm{E}-1$ & 51. $\mathrm{Na} 2 \mathrm{SO} 4$ \\
\hline 0 & 35. MnO & & \\
\hline
\end{tabular}

$\operatorname{CST}(1 \mathrm{bs}):$ Cs (1bs): Water (Ibs):
CST Sluxry Stream per Cycle 19610.75000

120.00445

176496.75000

Loading of Cs on CST (mg Cs/g CST): 6.11932

Cs Concentration (mol/L) in the salt solution along Columns (Values given at equal distance between inlet and outlet)

\begin{tabular}{|c|c|c|c|}
\hline & Column 1 & Column 2 & Column 3 \\
\hline & $0.85945 \mathrm{E}-4$ & $0.77346 \mathrm{E}-4$ & 0.0 \\
\hline & $0.85940 \mathrm{E}-4$ & $0.32032 \mathrm{E}-4$ & 0.0 \\
\hline & $0.85940 \mathrm{E}-4$ & $0.46958 \mathrm{E}-5$ & 0.0 \\
\hline & $0.85940 \mathrm{E}-4$ & $0.53148 \mathrm{E}-6$ & 0.0 \\
\hline & $0.85940 \mathrm{E}-4$ & $0.58167 \mathrm{E}-7$ & 0.0 \\
\hline & $0.85940 \mathrm{E}-4$ & $0.63296 \mathrm{E}-8$ & 0.0 \\
\hline & $0.85940 \mathrm{E}-4$ & $0.68700 \mathrm{E}-9$ & 0.0 \\
\hline & $0.85939 \mathrm{E}-4$ & 0.0 & 0.0 \\
\hline & $0.85919 \mathrm{E}-4$ & 0.0 & 0.0 \\
\hline & $0.85474 \mathrm{E}-4$ & 0.0 & 0.0 \\
\hline & $0.77346 \mathrm{E}-4$ & 0.0 & 0.0 \\
\hline
\end{tabular}


Figure 7.7: Result of Case 2/ Cycle 1

CASE :

Cycle Number:

Cycle Time (hrs):
YR2016

CYCLE1

694.47731

Salt Feed Stream

20.10000

10.41000

Flow rate (gpm):
Density (1b/gal): Mass fraction:

\begin{tabular}{|c|c|c|c|}
\hline 0.70144 & 1. & $\mathrm{H} 2 \mathrm{O}$ & 0 \\
\hline $0.58082 \mathrm{E}-2$ & 2 . & Misc. salts & 0 \\
\hline 0.16316 & 3 . & NaNO3 & 0 \\
\hline $0.19716 \mathrm{E}-1$ & 4. & NaNO2 & 0 \\
\hline $0.55115 E-1$ & 5. & $\mathrm{NaOH}$ & 0 \\
\hline $0.39000 E-5$ & 6. & KNO3 & 0 \\
\hline 0 & 7. & CsNO3 & 0 \\
\hline 0 & $8 .^{\circ}$ & NH 4 NO 3 & 0 \\
\hline 0 & 9. & $\mathrm{NH} 4 \mathrm{OH}$ & 0 \\
\hline $0.16677 \mathrm{E}-1$ & 10. & $\mathrm{NaALO} 2$ & 0 \\
\hline 0 & 11. & Misc. sludge & 0 \\
\hline 0 & 12 . & $\mathrm{Na} 2 \mathrm{U} 207$ & 0 \\
\hline 0 & 13. & $\mathrm{Fe}(\mathrm{OH}) 3$ & 0 \\
\hline 0 & 14. & Al $(\mathrm{OH}) 3$ & 0 \\
\hline 0 & 15. & $\mathrm{Cr}(\mathrm{OH}) 2$ & 0 \\
\hline 0 & 16. & $\mathrm{C} 6 \mathrm{H} 6$ & 0 \\
\hline 0 & 17. & Phenol/Phenoxide & 0 \\
\hline $0.25700 \mathrm{E}-4$ & 18. & $\mathrm{CsOH}$ & 0 \\
\hline $0.80870 \mathrm{E}-3$ & 19. & $\mathrm{KOH}$ & 0 \\
\hline 0 & 20 . & $\mathrm{CsB}(\mathrm{C} 6 \mathrm{H} 5) 4$ & $0.18500 \mathrm{E}-4$ \\
\hline 0 & 21 . & $\operatorname{NaB}(\mathrm{C} 6 \mathrm{H} 5) 4$ & 0 \\
\hline 0 & 22 . & $\mathrm{Na} 2(\mathrm{C} 6 \mathrm{H} 5) \mathrm{BO} 2$ & 0 \\
\hline 0 & 23 . & $\mathrm{KB}(\mathrm{C} 6 \mathrm{H} 5) 4$ & $0.15800 \mathrm{E}-1$ \\
\hline 0 & 24 . & NH4B (C6H5) 4 & $0.21423 \mathrm{E}-1$ \\
\hline 0 & 25 . & NaTi205H & \\
\hline 0 & 26. & $\operatorname{NaT} . \mathrm{S}(\mathrm{OH}) 2$ & \\
\hline
\end{tabular}

\begin{tabular}{|c|c|c|c|c|}
\hline & & & Additions & Salt Feed stream \\
\hline Inventory & er ( & (bs): & & 47000 \\
\hline $2 \mathrm{M} \mathrm{NaOH}$ sol & ion & (lbs): & & 23500 . \\
\hline Excess wate & to $\mathrm{s}$ & lurry $r$ & esin (1bs): & 25850 \\
\hline & & & Decontamina & ted salt solution \\
\hline Flow rate & m) : & & & 22.40525 \\
\hline Density (1b & a1): & & & 10.21514 \\
\hline Mass fracti & & & & \\
\hline 0.72528 & 1. & $\mathrm{H} 2 \mathrm{O}$ & & 0 \\
\hline $0.53128 \mathrm{E}-2$ & 2. & Misc. & salts & 0 \\
\hline 0.14924 & 3. & NaNO3 & & 0 \\
\hline $0.18035 \mathrm{E}-1$ & 4. & $\mathrm{NaNO} 2$ & & 0 \\
\hline $0.52067 \mathrm{E}-1$ & 5 . & $\mathrm{NaOH}$ & & 0 \\
\hline $0.35673 E-5$ & 6. & $\mathrm{KNO} 3$ & & 0 \\
\hline 0 & 7. & CsNO3 & & 0 \\
\hline 0 & 8. & NH4NO3 & & $0.73972 \mathrm{E}-3$ \\
\hline 0 & 9. & $\mathrm{NH} 4 \mathrm{OH}$ & & 0 \\
\hline $0.15255 E-1$ & 10. & $\mathrm{NaALO} 2$ & & 0 \\
\hline 0 & 11. & Misc. & sludge & 0 \\
\hline
\end{tabular}

27. NaT.Na2U2O7

28. (C6H5) 3B

29. (C6H5) $2 \mathrm{BOH}$

30. ( $6 \mathrm{H} 5)$ В (OH) 2

31. $\mathrm{B}(\mathrm{OH}) 3$

32. K2O

33. LiO2

34. MO

35. $\mathrm{MnO}$

36. TiO2

37. U308

38. $\mathrm{ZrO} 2$

39. Ca3P208

40. $\mathrm{P} 205$

41. $\mathrm{Cr} 2 \mathrm{O} 3$

42. $\mathrm{CsO} 2$

43. Cuo

44. $\mathrm{Na} 2 \mathrm{O}$

46. SiO2

47. HgO

48. alpha (PuO2)

49. $\mathrm{CaCO} 3$

50. $\mathrm{Na} 2 \mathrm{CO} 3$

51. $\mathrm{Na} 2 \mathrm{SO} 4$
12. $\mathrm{Na} 2 \mathrm{U} 2 \mathrm{O} 7$

13. $\mathrm{Fe}(\mathrm{OH}) 3$

14. AI (OH) 3

15. $\mathrm{Cr}(\mathrm{OH}) 2$

16. $\mathrm{C} 6 \mathrm{H} 6$

17. Phenol/Phenoxide

18. $\mathrm{CsOH}$

19. $\mathrm{KOH}$

20. $\mathrm{CsB}(\mathrm{C} 6 \mathrm{H} 5) 4$

21. $\mathrm{NaB}(\mathrm{C} 6 \mathrm{H} 5) 4$

22. $\mathrm{Na} 2(\mathrm{C} 6 \mathrm{H} 5) \mathrm{BO} 2$ 
0
0
0
0
0
0
0
0
0
0
0
0
0
0
0

CST (Ibs):

Cs (1bs):

Water (Ibs):
23. $\mathrm{KB}(\mathrm{C} 6 \mathrm{H} 5) 4$

24. $\mathrm{NH} 4 \mathrm{~B}(\mathrm{C} 6 \mathrm{H} 5) 4$

25. $\mathrm{NaTi} 2 \mathrm{O} 5 \mathrm{H}$

26. NaT.S $(\mathrm{OH}) 2$

27. NaT.Na2U2O7

28. (C6H5) $3 \mathrm{~B}$

29. (C6H5) $2 \mathrm{BOH}$

30. ( $6 \mathrm{H} 5) \mathrm{B}(\mathrm{OH}) 2$

31. $\mathrm{B}(\mathrm{OH}) 3$

32. K2O

33. LiO2

34. MO

35. MnO

36. TiO2

37. $\mathrm{U} 308$
38. $\mathrm{ZrO} 2$

39. Сa3P2O8

40. P2O5

41. Cr203

42. $\mathrm{CsO} 2$

43. CuO

44. $\mathrm{Na2O}$

45. NiO

46. $\mathrm{SiO} 2$

47. $\mathrm{HgO}$

48. alpha (PuO2)

49. $\mathrm{CaCO} 3$

50. $\mathrm{Na} 2 \mathrm{CO} 3$

51. $\mathrm{Na} 2 \mathrm{SO} 4$

Loading of Cs on CST (mg Cs/g CST): $\quad 9.58504$

Cs Concentration (mol/L) in the Salt Solution along Columns (Values given at equal distance between inlet and outlet)

\begin{tabular}{|c|c|c|c|}
\hline & Column 1 & CoIumn 2 & Colúmn 3 \\
\hline & $0.19196 \mathrm{E}-3$ & $0.17275 \mathrm{E}-3$ & 0.0 \\
\hline & $0.19195 \mathrm{E}-3$ & $0.29449 \mathrm{E}-4$ & 0.0 \\
\hline & $0.19195 \mathrm{E}-3$ & $0.15229 \mathrm{E}-5$ & 0.0 \\
\hline & $0.19195 \mathrm{E}-3$ & $0.72154 \mathrm{E}-7$ & 0.0 \\
\hline & $0.19195 \mathrm{E}-3$ & $0.34005 \mathrm{E}-8$ & 0.0 \\
\hline & $0.19195 \mathrm{E}-3$ & $0.15984 \mathrm{E}-9$ & 0.0 \\
\hline & $0.19195 \mathrm{E}-3$ & 0.0 & 0.0 \\
\hline & $0.19195 \mathrm{E}-3$ & 0.0 & 0.0 \\
\hline & $0.19195 \mathrm{E}-3$ & 0.0 & 0.0 \\
\hline & $0.19179 \mathrm{E}-3$ & 0.0 & 0.0 \\
\hline & $0.17275 \mathrm{E}-3$ & 0.0 & 0.0 \\
\hline
\end{tabular}


Figure 7.8: Result of Case 2/ Cycle 2

CASE :

Cycle Number:

Cycle Time (hrs):
YR2016

CYCLE2

656.81178

Salt Feed Stream

Flow rate (g
Density (Ib/
Mass fraction:
0.70144
$0.58082 \mathrm{E}-2$
0.16316
$0.19716 \mathrm{E}-1$
$0.55115 \mathrm{E}-1$
$0.39000 \mathrm{E}-5$
0
0
0
$0.16677 \mathrm{E}-1$
0
0
0
0
0
0
0
$0.25700 \mathrm{E}-4$
$0.80870 \mathrm{E}-3$
0
0
0
0
0
0
0

20.10000
10.41000

0

0

0

3. NaNO3

4. $\mathrm{NaNO} 2$

5. $\mathrm{NaOH}$

6. $\mathrm{KNO} 3$

7. $\mathrm{CsNO} 3$

8. NH4NO3

9. $\mathrm{NH} 4 \mathrm{OH}$

10. NaALO2

11. Misc. sludge

12. $\mathrm{Na} 2 \mathrm{U} 2 \mathrm{O} 7$

13. $\mathrm{Fe}(\mathrm{OH}) 3$

14. $\mathrm{Al}(\mathrm{OH}) 3$

15. $\mathrm{Cr}(\mathrm{OH}) 2$

16. $\mathrm{C} 6 \mathrm{H} 6$

17. Phenol/Phenoxide

19. $\mathrm{KOH}$

20. $\mathrm{CsB}$ (C6H5) 4

21. $\mathrm{NaB}(\mathrm{C} 6 \mathrm{H} 5) 4$

22. $\mathrm{Na} 2(\mathrm{C} 6 \mathrm{H} 5) \mathrm{BO} 2$

23. $\mathrm{KB}$ (C6H5) 4

24. $\mathrm{NH} 4 \mathrm{~B}(\mathrm{C} 6 \mathrm{H} 5) 4$

25. NaTi2O5H

26. $\mathrm{NaT} . \mathrm{S}(\mathrm{OH}) 2$
18. $\mathrm{CsOH}$
27. NaT.Na2U2O7

28. (C6H5) 3B

29. (C6H5) $2 \mathrm{BOH}$

30. (C6H5) B (OH) 2

31. $\mathrm{B}(\mathrm{OH}) 3$

32. $\mathrm{K} 2 \mathrm{O}$

33. LiO2

34. MO

35. $\mathrm{MnO}$

36. TiO2

37. U308

38. $\mathrm{ZrO} 2$

39. Сa3P2O8

40. $\mathrm{P} 2 \mathrm{O} 5$

41. $\mathrm{Cr} 203$

42. $\mathrm{CsO} 2$

43. CuO

44. $\mathrm{Na} 2 \mathrm{O}$

45. NiO

46. SiO2

47. $\mathrm{HgO}$

48. alpha (PuO2)

49. $\mathrm{CaCO} 3$

50. $\mathrm{Na} 2 \mathrm{CO} 3$

$0.15800 \mathrm{E}-1$

$0.21423 \mathrm{E}-1$

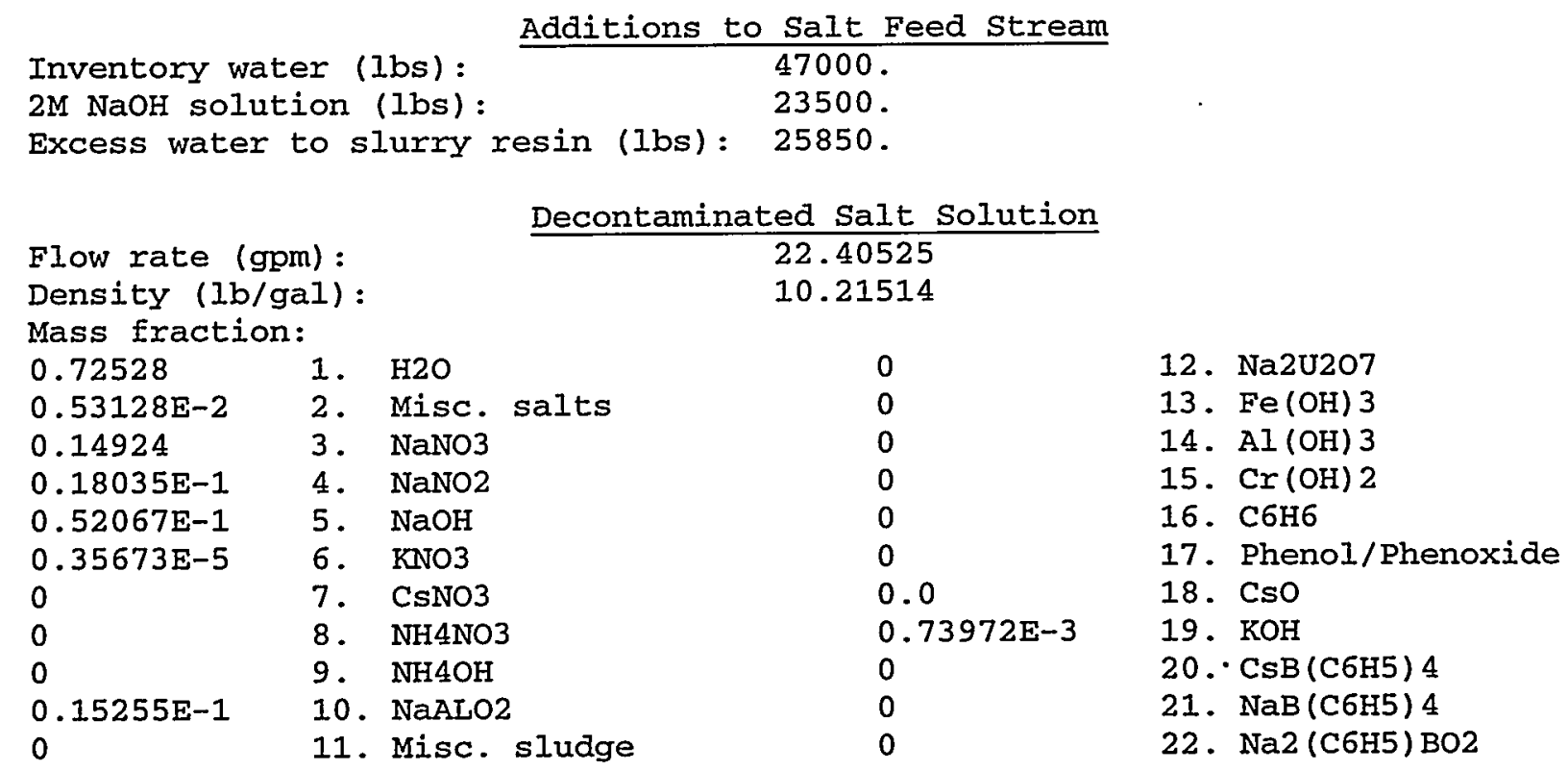




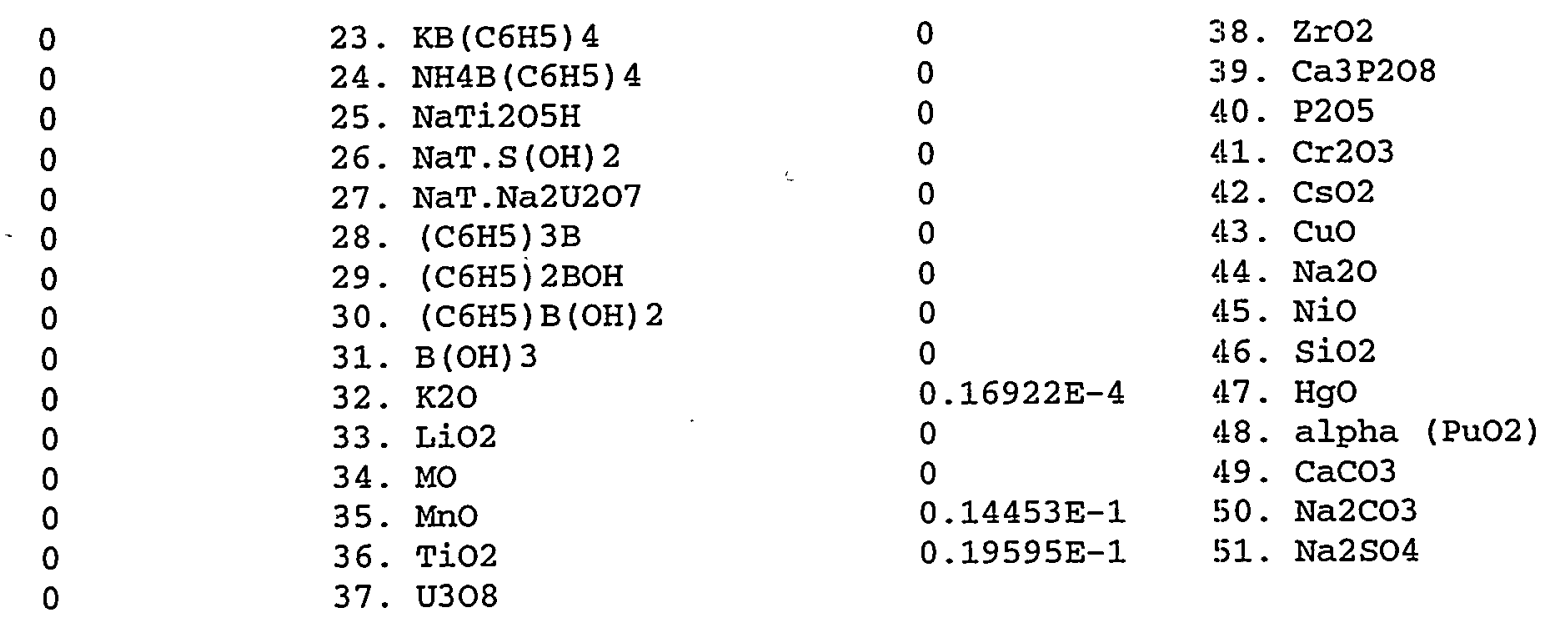

CST (1bs):

Cs (1bs):

Water (Ibs):
CST Slurry Stream per Cycle

19610.75000

187.96974

176496.75000

Loading of Cs on CST (mg Cs/g CST): 9.58504

Cs Concentration (mol/L) in the Salt Solution along Columns (Values given at equal distance between inlet and outlet)

\begin{tabular}{|c|c|c|c|}
\hline & Column 1 & Column 2 & Column 3 \\
\hline & $0.19196 \mathrm{E}-3$ & $0.17275 \mathrm{E}-3$ & 0.0 \\
\hline & $0.19195 \mathrm{E}-3$ & $0.29453 \mathrm{E}-4$ & 0.0 \\
\hline & $0.19195 \mathrm{E}-3$ & $0.15234 \mathrm{E}-5$ & 0.0 \\
\hline & $0.19195 \mathrm{E}-3$ & $0.72225 \mathrm{E}-7$ & 0.0 \\
\hline & $0.19195 \mathrm{E}-3$ & $0.34096 \mathrm{E}-8$ & 0.0 \\
\hline & $0.19195 \mathrm{E}-3$ & $0.16089 \mathrm{E}-9$ & 0.0 \\
\hline & $0.19195 \mathrm{E}-3$ & 0.0 & 0.0 \\
\hline & $0.19195 \mathrm{E}-3$ & 0.0 & 0.0 \\
\hline & $0.19195 \mathrm{E}-3$ & 0.0 & 0.0 \\
\hline & $0.19179 \mathrm{E}-3$ & 0.0 & 0.0 \\
\hline & $0.17275 \mathrm{E}-3$ & 0.0 & 0.0 \\
\hline
\end{tabular}


Figure 7.9: Result of Case 2/ Cycle 3

CASE :

Cycle Number:

Cycle Time (hrs):

Flow rate $(\mathrm{gpm})$ :

Density (Ib/gal):

Mass fraction:

0.70144

$0.58082 \mathrm{E}-2 \quad 2$. Misc. salts

0.163163 3aNO3

$0.19716 \mathrm{E}-1$ 4. NaNO2

$0.55115 \mathrm{E}-1$ 5. $\mathrm{NaOH}$

$0.39000 \mathrm{E}-5$ 6. KNO3

7. $\mathrm{CsNO} 3$

8. $\mathrm{NH} 4 \mathrm{NO} 3$

9. $\mathrm{NH} 4 \mathrm{OH}$

$0.16677 \mathrm{E}-1$ 10. NaALO2

11. Misc. sludge

12. $\mathrm{Na} 2 \mathrm{U} 2 \mathrm{O} 7$

13. $\mathrm{Fe}(\mathrm{OH}) 3$

14. $\mathrm{AI}(\mathrm{OH}) 3$

15. $\mathrm{Cr}(\mathrm{OH}) 2$

16. $\mathrm{C} 6 \mathrm{H} 6$

17. Phenol/Phenoxide

$0.25700 \mathrm{E}-4$

18. $\mathrm{CsOH}$

19. $\mathrm{KOH}$

20. $\mathrm{CsB}(\mathrm{C} 6 \mathrm{H} 5) 4$
YR2016

CYCLE3

656.80895

Salt Feed Stream

20.10000

10.41000
$0.80870 \mathrm{E}-3$
21. $\mathrm{NaB}(\mathrm{C} 6 \mathrm{H} 5) 4$

22. $\mathrm{Na} 2(\mathrm{C} 6 \mathrm{H} 5) \mathrm{BO} 2$

23. $\mathrm{KB}(\mathrm{C} 6 \mathrm{H} 5) 4$

24. $\mathrm{NH} 4 \mathrm{~B}(\mathrm{C} 6 \mathrm{H} 5) 4$

25. NaTi2O5H

26. NaT.S $(\mathrm{OH}) 2$

Additions to Salt Feed Stream
$\begin{aligned} 47000 \\ 23500 .\end{aligned}$
resin (Ibs) $=$
25850.

Decontaminated Salt Solution 22.40525

10.21514

low rate $(\mathrm{gpm})$ :

Density (1b/gal):

$0.18500 \mathrm{E}-4$

$0.15800 \mathrm{E}-1$

$0.21423 \mathrm{E}-1$
27. NaT.Na2U2O7

28. (C6H5) 3B

29. (C6H5) $2 \mathrm{BOH}$

30. (C6H5) В (OH) 2

31. $\mathrm{B}(\mathrm{OH}) 3$

32. $\mathrm{K} 2 \mathrm{O}$

33. LiO2

34. MO

35. $\mathrm{MnO}$

36. TiO2

37. U308

38. $\mathrm{ZrO} 2$

39. Сa3P2O8

40. P205

41. Cr203

42. $\mathrm{CsO} 2$

43. CuO

44. $\mathrm{Na} 2 \mathrm{O}$

45. NiO

46. $\mathrm{SiO} 2$

47. $\mathrm{HgO}$

48. Alpha (PuO2)

49. $\mathrm{CaCO} 3$

50. $\mathrm{Na} 2 \mathrm{CO} 3$

51. $\mathrm{Na} 2 \mathrm{SO} 4$

Mass fraction:

$\begin{array}{lll}0.72528 & 1 . & \mathrm{H} 2 \mathrm{O} \\ 0.53128 \mathrm{E}-2 & 2 . & \mathrm{Misc} . \text { salts } \\ 0.14924 & \text { 3. } & \mathrm{NaNO} 3 \\ 0.18035 \mathrm{E}-1 & 4 . & \mathrm{NaNO} 2 \\ 0.52067 \mathrm{E}-1 & 5 . & \mathrm{NaOH} \\ 0.35673 \mathrm{E}-5 & \text { 6. } & \mathrm{KNO} 3 \\ & 7 . & \mathrm{CsNO} 3 \\ & \text { 8. } \mathrm{NH} 4 \mathrm{NO} 3 \\ & 9 . & \mathrm{NH} 4 \mathrm{OH} \\ 0.15255 \mathrm{E}-1 & 10 . & \mathrm{NaALO} 2\end{array}$

11. Misc. sludge

12. $\mathrm{Na} 2 \mathrm{U} 2 \mathrm{O} 7$

13. $\mathrm{Fe}(\mathrm{OH}) 3$

14. AI $(\mathrm{OH}) 3$

15. $\mathrm{Cr}(\mathrm{OH}) 2$

16. $\mathrm{C} 6 \mathrm{H} 6$

17. Phenol/Phenoxide

$\begin{array}{ll}0.0 & 18 . \mathrm{CsOH} \\ 0.73972 \mathrm{E}-3 & 19 . \mathrm{KOH}\end{array}$

20. $\mathrm{CsB}(\mathrm{C} 6 \mathrm{H} 5) 4$

21. $\mathrm{NaB}(\mathrm{C} 6 \mathrm{H} 5) 4$ 
22. $\mathrm{Na} 2(\mathrm{C} 6 \mathrm{H} 5) \mathrm{BO} 2$

23. $\mathrm{KB}(\mathrm{C} 6 \mathrm{H} 5) 4$

24. NH4B (C6H5) 4

25. NaTi205H

26. NaT.S $(\mathrm{OH}) 2$

27. NaT.Na2U2O7

28. (C6H5) $3 \mathrm{~B}$

29. (C6H5) $2 \mathrm{BOH}$

30. (C6H5) В $(\mathrm{OH}) 2$

31. $\mathrm{B}(\mathrm{OH}) 3$

32. K2O

33. LiO2

34. MO

35. $\mathrm{MnO}$

36. TiO2
37. U308

3. $\mathrm{ZrO} 2^{\circ}$

39. Ca3P208

40. P205

41. $\operatorname{Cr} 203$

42. $\mathrm{CsO} 2$

43. CuO

44. $\mathrm{Na} 2 \mathrm{O}$

45. NiO

46. SiO2

47. $\mathrm{HgO}$

48. Alpha (PuO2)

49. $\mathrm{CaCO} 3$

$0.14453 \mathrm{E}-1$ 50. $\mathrm{Na} 2 \mathrm{CO} 3$

$0.19595 \mathrm{E}-1$ 51. Na2SO4
CST (1bs):

Cs (Ibs):

Water (Ibs):
CST slurry stream per Cycle

19610.75000

187.96976

176496.75000

\section{Loading of Cs on CST (mg Cs/g CST): 9.58504}

Cs Concentration ( $\mathrm{mol} / \mathrm{L}$ ) in the salt solution along columns (Values given at equal distance between inlet and outlet)

\begin{tabular}{|c|c|c|c|}
\hline & Column 1 & Column 2 & Column 3 \\
\hline & $0.19196 \mathrm{E}-3$ & $0.17275 \mathrm{E}-3$ & 0.0 \\
\hline & $0.19195 \mathrm{E}-3$ & $0.29453 \mathrm{E}-4$ & 0.0 \\
\hline & $0.19195 \mathrm{E}-3$ & $0.15234 \mathrm{E}-5$ & 0.0 \\
\hline & $0.19195 \mathrm{E}-3$ & $0.72225 \mathrm{E}-7$ & 0.0 \\
\hline & $0.19195 \mathrm{E}-3$ & $0.34096 \mathrm{E}-8$ & 0.0 \\
\hline & $0.19195 \mathrm{E}-3$ & $0.16089 \mathrm{E}-9$ & 0.0 \\
\hline & $0.19195 \mathrm{E}-3$ & 0.0 & 0.0 \\
\hline & $0.19195 \mathrm{E}-3$ & 0.0 & 0.0 \\
\hline & $0.19195 \mathrm{E}-3$ & 0.0 & 0.0 \\
\hline & $0.19179 \mathrm{E}-3$ & 0.0 & 0.0 \\
\hline
\end{tabular}




\section{DIRECT DISPOSAL IN GROUT}

\subsection{Direct Disposal in Grout Material Balance Model Description}

Figure 8.1 shows a schematic representation of the Direct Disposal in Grout material balance model. This is the same model that was described in Section 3.2; it is repeated here for the convenience of the reader.

The model feeds salt solution in $60 \mathrm{kgal}$ batches into the AST. MST slurry (11 wt\% MST in water) is added to the tank in $1 \%$ excess over the stochiometric amount required to complex uranium, strontium and plutonium salts in the solution. Each AST batch is held for 24 hours to simulate the adsorption process. Following the hold time, the AST batch is continuously passed through a filtration step. A stream is added to the effluent from the AST to simulate water added from the ETF and water added to wash the AST. The filter is assumed to be $100 \%$ efficient in removing solids from the incoming salt solution. The solids fraction includes metal oxides, MST and MST complexes that are in solution. Output from the filter is separated into filtrate and solids slurry streams. Water is added to the solids stream at the specified flush ratio of 16.69 pounds of water per pound of solids. The filtrate is collected in the SSHT and from there fed continuously to the grout plant. The solids fraction is collected in the SSRT. Material collected in the SSRT is added as an input stream to the SRAT in the DWPF model with the volume prorated over each SRAT batch as:

$$
V_{\text {SRAT }}=\frac{\text { SRAT Cycle Time }}{\text { SSRT Collection Time }} V_{\text {SSRT }}
$$

where $V_{S R A T}$ is the volume of slurry added to each SRAT batch.

In the grout plant model, cement, fly ash and slag are added as premix at the nominal composition [1] to the salt solution. The three components were mixed in the weight ratio of 3:25:25 for cement, fly ash and slag, respectively into a single composite material used in the model. A water-to-premix ratio of 0.57 is used to determine the amount of premix to add to the incoming salt solution. The model checks that the salt solution meets the processing constraints of at most $4600 \mathrm{Ci}{ }^{137} \mathrm{Cs}$ per cubic meter and $6.0 \mathrm{M}$ sodium. If the solution exceeds these values, dilution water is added such that the constraints will be met. A grout specific gravity of 1.7 is used to calculate the volume of grout made.

\subsection{Direct Disposal in Grout Model Results for FY 2010 Salt Blend}

The following output was obtained directly from report GROUT written by the SPEEDUP model from a representative calculation made with the Direct Disposal in Grout model. This report shows the primary flow streams in the models and either the stream density or mass flowrate. In the grout model, the first 41 hours of operation are taken up processing the first batch through the alpha decontamination process. Thereafter (i.e. for the remaining 1441 hours of the simulation) the model is running continuously. The Waste Processed represents the volume of salt solution that has passed through the entire process. 


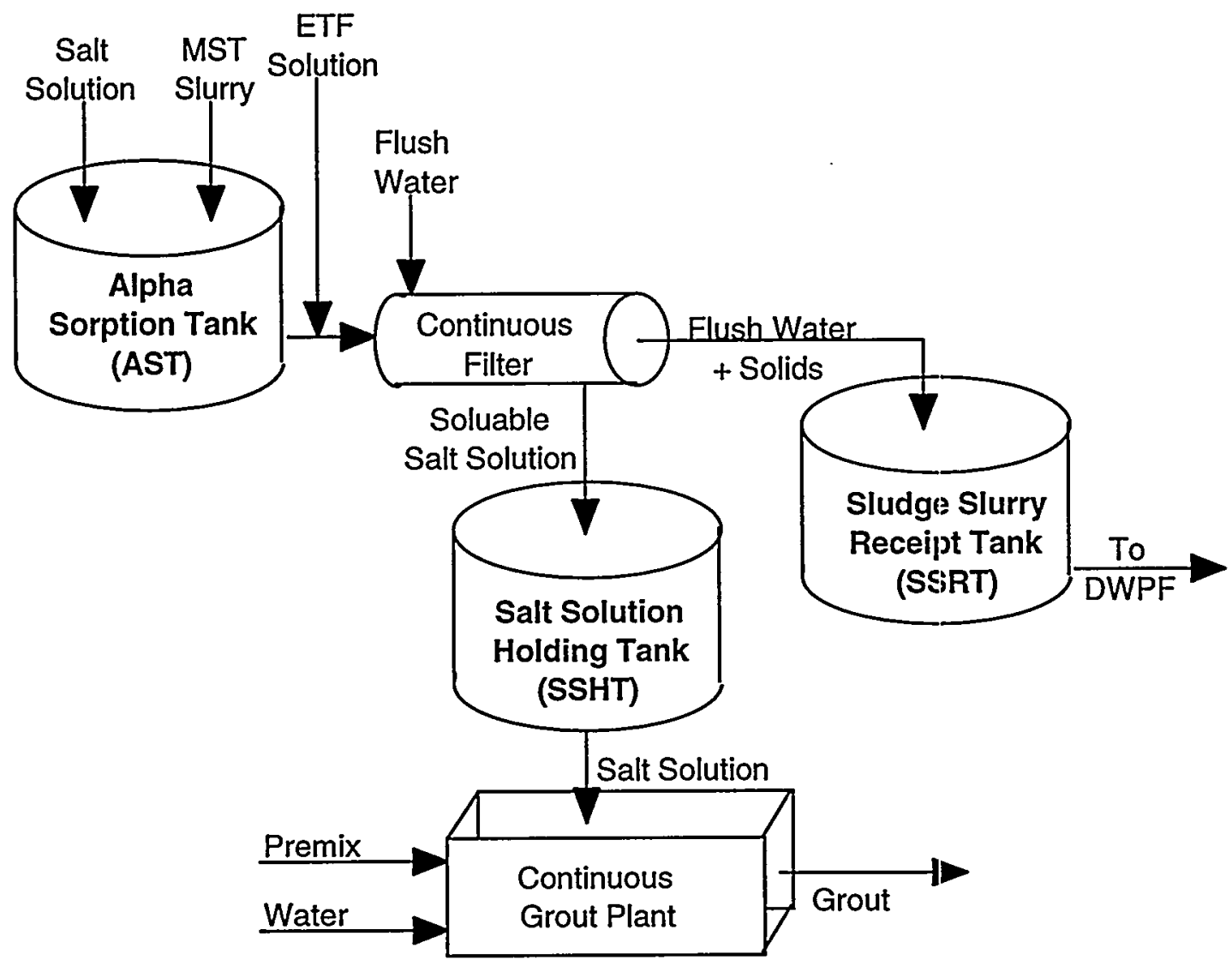

Figure 8.1 Schematic representation of Direct Disposal in Grout model. 


\section{Report GROUT}

\begin{tabular}{|c|c|c|c|c|c|}
\hline $\begin{array}{c}\text { Simulation Time } \\
\text { Operating Time }\end{array}$ & $\begin{array}{l}= \\
=\end{array}$ & $\begin{array}{l}1482.000 \\
1440.949\end{array}$ & $\begin{array}{l}\text { hours } \\
\text { hours }\end{array}$ & & \\
\hline $\begin{array}{l}\text { Waste sent to AST } \\
\text { Waste Processed }\end{array}$ & $\begin{array}{l}= \\
=\end{array}$ & $\begin{array}{l}1440.002 \\
1314.452\end{array}$ & $\begin{array}{l}\text { kgal } \\
\text { kgal }\end{array}$ & $\begin{array}{l}8754.245 \\
7990.985\end{array}$ & $\begin{array}{l}\text { kgaliyr } \\
\text { kgaliyr }\end{array}$ \\
\hline Processing Rate & $=$ & 15.204 & gpm & & \\
\hline MST Volume Used & $=$ & 11.922 & kgal & 72.479 & kgaliyr \\
\hline AST Water Added & $=$ & 100.290 & kgal & 609.696 & $\mathrm{kgal} / \mathrm{yr}$ \\
\hline ETF Bottoms & $=$ & 29.395 & kgal & 178.704 & kgaliyr \\
\hline $\begin{array}{l}\text { Grout Volume Made } \\
\text { Dilution Water }\end{array}$ & $\begin{array}{l}= \\
=\end{array}$ & $\begin{array}{r}2568.271 \\
0.533\end{array}$ & $\begin{array}{l}\text { kgal } \\
\text { kgal }\end{array}$ & $\begin{array}{r}15613.364 \\
3.242\end{array}$ & $\begin{array}{l}\text { kgal'yr } \\
\text { kgal/yx }\end{array}$ \\
\hline $\begin{array}{l}\text { Volume in AST } \\
\text { Volume in SSHT }\end{array}$ & $\begin{array}{l}= \\
=\end{array}$ & $\begin{array}{l}64.834 \\
60.716\end{array}$ & $\begin{array}{l}\text { kgal } \\
\text { kgal }\end{array}$ & & \\
\hline $\begin{array}{l}\text { Volume in SSRT } \\
\text { (SSRT } \rightarrow \text { DWPF) }\end{array}$ & $=$ & 47.778 & $\mathrm{kgal}$ & 290.460 & $\mathrm{kgal} / \mathrm{yr}$ \\
\hline
\end{tabular}

1. Salt Solution Feed to AST Salt Solution Density $\quad 10.7000 \mathrm{lb} / \mathrm{gal}$

\begin{tabular}{|c|c|c|c|c|c|}
\hline $\mathrm{H} 2 \mathrm{O}$ & 0.6817 & salt & $0.5400 \mathrm{E}-2$ & NaNO3 & 0.1534 \\
\hline NaNO2 & $0.2778 \mathrm{E}-1$ & $\mathrm{NaOH}$ & $0.7847 \mathrm{E}-1$ & KNO3 & $0.1410 \mathrm{E}-3$ \\
\hline CsNO3 & 0 & NH4NO3 & $0.1110 \mathrm{E}-4$ & NH4OH & $\mathbf{0}$ \\
\hline $\mathrm{NaA1O} 2$ & $0.2103 E-1$ & sludge & $0.3290 \mathrm{E}-3$ & $\mathrm{Na} 2 \mathrm{U} 207$ & $0.5510 E-3$ \\
\hline $\mathrm{Fe}(\mathrm{OH}) 3$ & 0 & $\mathrm{Al}(\mathrm{OH}) 3$ & 0 & $\mathrm{Sr}(\mathrm{OH}) 2$ & 0 \\
\hline с6 6 H6 & 0 & $\mathrm{C} 6 \mathrm{H} 5 \mathrm{OH}$ & 0 & $\mathrm{CsOH}$ & $0.2170 \mathrm{E}-4$ \\
\hline $\mathrm{KOH}$ & $0.1100 \mathrm{E}-2$ & CsTPB & 0 & NaTPB & $\mathbf{0}$ \\
\hline NaDPB & 0 & KTPB & 0 & NH4TPB & 0 \\
\hline MST & 0 & MSTSr & 0 & MSTU & 0 \\
\hline (C6H5) 3B & 0 & (C6H5) $2 \mathrm{BOH}$ & 0 & $(\mathrm{C} 6 \mathrm{H} 5) \mathrm{B}(\mathrm{OH}) 2$ & 0 \\
\hline $\mathrm{B}(\mathrm{OH}) 3$ & 0 & $\mathrm{~K} 2 \mathrm{O}$ & 0 & Li20 & 0 \\
\hline MgO & 0 & Mno & 0 & TiO2 & 0 \\
\hline U308 & 0 & $\mathrm{ZrO} 2$ & 0 & Ca3P2O8 & 0 \\
\hline P205 & 0 & Cr2O3 & 0 & $\mathrm{Cs} 2 \mathrm{O}$ & 0 \\
\hline Cuo & 0 & $\mathrm{Na2O}$ & 0 & $\mathrm{NiO}$ & 0 \\
\hline $\mathrm{SiO} 2$ & 0 & HgO & $0.4220 E-4$ & PuO2 & 0 \\
\hline $\mathrm{CaCO} 3$ & 0 & $\mathrm{Na} 2 \mathrm{CO} 3$ & $0.1717 \mathrm{E}-1$ & $\mathrm{Na} 2 \mathrm{SO} 4$ & $0.1342 \mathrm{E}-1$ \\
\hline
\end{tabular}

2. ETF Solution Feed to AST ETF Solution Density $\quad 10.4000 \mathrm{lb} / \mathrm{gal}$

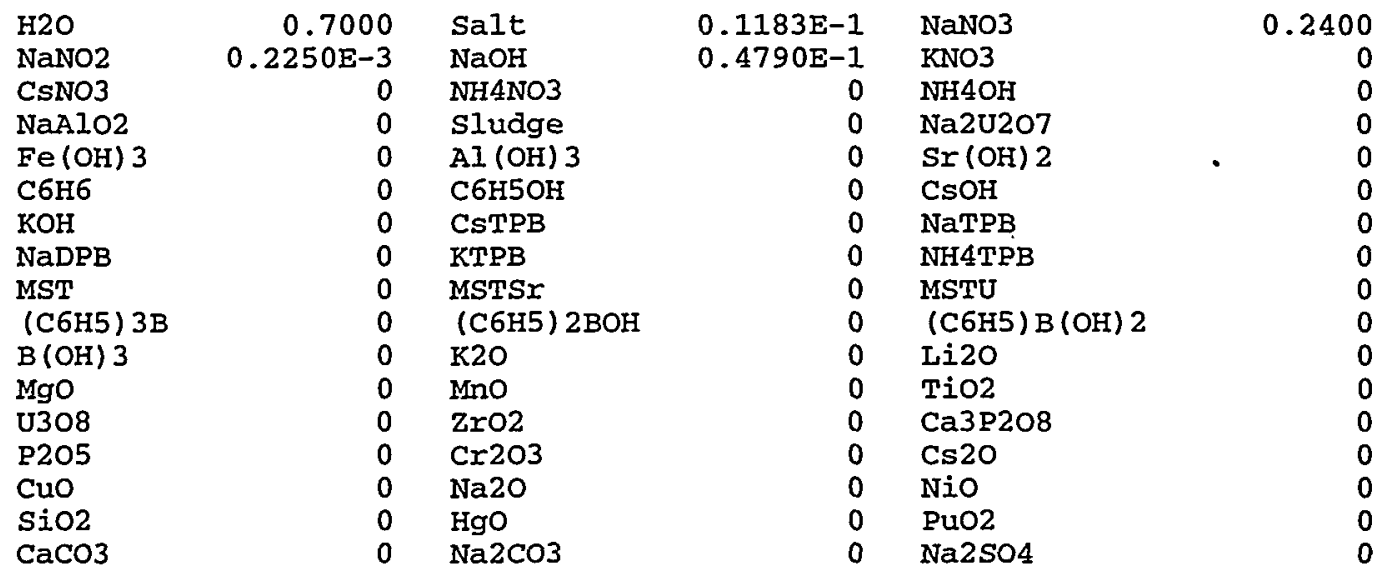


3. Filtrate Composition in SSHT

Filtrate solution Density

$\begin{array}{lrl}\text { H2O } & 0.7031 & \text { Salt } \\ \text { NaNO2 } & 0.2543 \mathrm{E}-1 & \text { NaOH } \\ \text { CsNO3 } & 0 & \text { NH4NO3 } \\ \text { NaA1O2 } & 0.1925 \mathrm{E}-1 & \text { Sludge } \\ \text { Fe(OH) } 3 & 0 & \text { Al(OH) 3 } \\ \text { C6H6 } & 0 & \text { C6H5OH } \\ \text { KOH } & 0.1007 \mathrm{E}-2 & \text { CsTPB } \\ \text { NaDPB } & 0 & \text { KTPB } \\ \text { MST } & 0.0 & \text { MSTSr } \\ \text { (C6H5) 3B } & 0 & \text { (C6H5) 2BOH } \\ \text { B(OH) 3 } & 0 & \text { K2O } \\ \text { MgO } & 0 & \text { MnO } \\ \text { U3O8 } & 0 & \text { ZrO2 } \\ \text { P2O5 } & 0 & \text { Cr2O3 } \\ \text { CuO } & 0 & \text { Na2O } \\ \text { SiO2 } & 0 & \text { HgO } \\ \text { CaCO3 } & 0 & \text { Na2CO3 }\end{array}$

$9.9862 \mathrm{lb} / \mathrm{gal}$

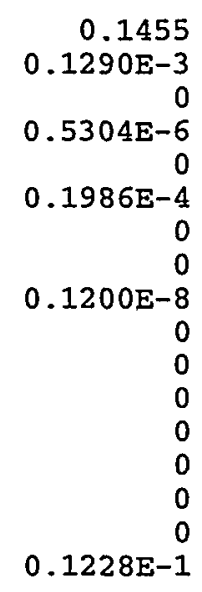

$0.1228 \mathrm{E}-1$

4. Composition of Filtered Sludge Solution in SSRT

$\begin{array}{rl}0.5195 \mathrm{E}-2 & \mathrm{NaNO} 3 \\ 0.7232 \mathrm{E}-1 & \mathrm{KNO} 3 \\ 0.1016 \mathrm{E}-4 & \mathrm{NH} 4 \mathrm{OH} \\ 0.0 & \mathrm{Na2U2O7} \\ 0 & \mathrm{Sr}(\mathrm{OH}) 2 \\ 0 & \mathrm{CsOH} \\ 0 & \mathrm{NaTPB} \\ 0 & \mathrm{NH} 4 \mathrm{TPB} \\ 0 & \mathrm{MSTU} \\ 0 & (\mathrm{C} 6 \mathrm{H} 5) \mathrm{B}(\mathrm{OH}) 2 \\ 0 & \text { Li2O } \\ 0 & \mathrm{TiO} 2 \\ 0 & \mathrm{Ca} 3 \mathrm{P} 2 \mathrm{O} 8 \\ 0 & \mathrm{Cs} 2 \mathrm{O} \\ 0 & \mathrm{NiO} \\ 0.3862 \mathrm{E}-4 & \text { PuO2 } \\ 0.1571 \mathrm{E}-1 & \mathrm{Na} 2 \mathrm{SO} 4\end{array}$
sludge Solution Density

4

\begin{tabular}{|c|c|c|}
\hline $\mathrm{H} 2 \mathrm{O}$ & 0.9250 & Salt \\
\hline NaNO2 & 0 & $\mathrm{NaOH}$ \\
\hline CsNO3 & 0 & NH4NO3 \\
\hline $\mathrm{NaAlO} 2$ & 0 & sludge \\
\hline $\mathrm{Fe}(\mathrm{OH}) 3$ & 0 & $\mathrm{AI}(\mathrm{OH}) 3$ \\
\hline $\mathrm{C} 6 \mathrm{H} 6$ & 0 & $\mathrm{C} 6 \mathrm{H} 5 \mathrm{OH}$ \\
\hline $\mathrm{KOH}$ & 0 & CSTPB \\
\hline NaDPB & 0 & KTPB \\
\hline MST & $0.2458 \mathrm{E}-2$ & MSTSr \\
\hline (C6H5) 3B & 0 & (C6H5) $2 \mathrm{BOH}$ \\
\hline $\mathrm{B}(\mathrm{OH}) 3$ & 0 & $\mathrm{~K} 2 \mathrm{O}$ \\
\hline Mgo & 0 & Mno \\
\hline U308 & 0 & $\mathrm{ZrO} 2$ \\
\hline P205 & 0 & $\operatorname{Cr} 203$ \\
\hline $\mathrm{CuO}$ & 0 & $\mathrm{Na} 2 \mathrm{O}$ \\
\hline $\mathrm{SiO} 2$ & 0 & $\mathrm{HgO}$ \\
\hline $\mathrm{CaCO} 3$ & 0 & $\mathrm{Na} 2 \mathrm{CO} 3$ \\
\hline
\end{tabular}

\section{$8.7495 \mathrm{Ib} / \mathrm{gal}$}

\begin{tabular}{|c|c|c|}
\hline 0 & NaNO3 & 0 \\
\hline $0.2000 E-1$ & KNO3 & 0 \\
\hline 0 & $\mathrm{NH} 4 \mathrm{OH}$ & 0 \\
\hline $0.1162 \mathrm{E}-1$ & $\mathrm{Na2U207}$ & 0 \\
\hline 0 & $\mathrm{Sr}(\mathrm{OH}) 2$ & 0 \\
\hline 0 & $\mathrm{CsOH}$ & 0 \\
\hline 0 & NaTPB & 0 \\
\hline 0 & NH4TPB & 0 \\
\hline 0 & MSTU & $0.4095 \mathrm{E}-1$ \\
\hline 0 & $(\mathrm{C} 6 \mathrm{H} 5) \mathrm{B}(\mathrm{OH}) 2$ & 0 \\
\hline 0 & Ii2O & 0 \\
\hline 0 & TiO2 & 0 \\
\hline 0 & Ca3P2O8 & 0 \\
\hline 0 & $\mathrm{Cs} 2 \mathrm{O}$ & 0 \\
\hline 0 & NiO & 0 \\
\hline 0 & Puo2 & 0 \\
\hline 0 & $\mathrm{Na} 2 \mathrm{SO} 4$ & 0 \\
\hline
\end{tabular}

5. Grout Plant salt Solution Feed Flow and Composition salt solution Flow $10.6653 \mathrm{klb} / \mathrm{hr}$

\begin{tabular}{|c|c|c|c|c|c|}
\hline $\begin{array}{l}\mathrm{H} 2 \mathrm{O} \\
\mathrm{NaNO} 2\end{array}$ & $\begin{array}{r}0.7031 \\
0.2543 \mathrm{E}-1\end{array}$ & $\begin{array}{l}\text { Salt } \\
\mathrm{NaOH}\end{array}$ & $\begin{array}{l}0.5195 E-2 \\
0.7232 E-1\end{array}$ & $\begin{array}{l}\text { NaNO3 } \\
\text { KNO3 }\end{array}$ & $\begin{array}{r}0.1455 \\
0.1290 \mathrm{E}-3\end{array}$ \\
\hline CsNO3 & 0 & NH4NO3 & $0.1016 \mathrm{E}-4$ & $\mathrm{NH} 4 \mathrm{OH}$ & 0 \\
\hline $\mathrm{NaAlO} 2$ & $0.1925 \mathrm{E}-1$ & sludge & 0.0 & $\mathrm{Na} 2 \mathrm{U} 207$ & $0.5304 \mathrm{E}-6$ \\
\hline $\mathrm{Fe}(\mathrm{OH}) 3$ & 0 & $\mathrm{~A} I(\mathrm{OH}) 3$ & 0 & $\mathrm{Sr}(\mathrm{OH}) 2$ & 0 \\
\hline $\mathrm{C} 6 \mathrm{H} 6$ & 0 & $\mathrm{C} 6 \mathrm{H} 5 \mathrm{OH}$ & 0 & $\mathrm{CsOH}$ & $0.1986 \mathrm{E}-4$ \\
\hline $\mathrm{KOH}$ & $0.1007 \mathrm{E}-2$ & CSTPB & 0 & NaTPB & 0 \\
\hline NaDPB & 0 & RTPB & 0 & NHATPB & 0 \\
\hline MST & 0.0 & MSTSr & 0 & MSTU & $0.1200 \mathrm{E}-8$ \\
\hline (C6H5) 3B & 0 & (C6H5) $2 \mathrm{BOH}$ & 0 & $(\mathrm{C} 6 \mathrm{H} 5) \mathrm{B}(\mathrm{OH}) 2$ & 0 \\
\hline $\mathrm{B}(\mathrm{OH}) 3$ & 0 & $\mathrm{~K} 2 \mathrm{O}$ & 0 & Li20 & 0 \\
\hline Mgo & 0 & Mno & 0 & TiO2 & 0 \\
\hline U308 & 0 & $\mathrm{ZrO} 2$ & 0 & Ca3P2O8 & 0 \\
\hline P205 & 0 & Cr2O3 & 0 & $\mathrm{Cs} 2 \mathrm{O}$ & 0 \\
\hline Cuo & 0 & $\mathrm{Na2O}$ & 0 & $\mathrm{NiO}$ & 0 \\
\hline $\mathrm{SiO} 2$ & 0 & HgO & $0.3862 E-4$ & Puo2 & 0 \\
\hline $\mathrm{CaCO} 3$ & 0 & $\mathrm{Na} 2 \mathrm{CO} 3$ & $0.1571 \mathrm{E}-1$ & $\mathrm{Na} 2 \mathrm{SO} 4$ & $0.1228 \mathrm{E}-1$ \\
\hline
\end{tabular}


6. Grout Plant Premix Feed Flow and Composition

Premix Flow $\quad 14.0905 \mathrm{klb} / \mathrm{hr}$

\begin{tabular}{|c|c|c|c|c|c|}
\hline $\mathrm{H} 2 \mathrm{O}$ & 0 & Salt & 0 & NaNO3 & 0 \\
\hline NaNO2 & 0 & $\mathrm{NaOH}$ & 0 & KNO3 & 0 \\
\hline CsNO3 & 0 & NH4NO3 & 0 & $\mathrm{NH} 4 \mathrm{OH}$ & 0 \\
\hline $\mathrm{NaAlO} 2$ & 0 & sludge & 0 & $\mathrm{Na} 2 \mathrm{U} 2 \mathrm{O} 7$ & 0 \\
\hline $\mathrm{Fe}(\mathrm{OH}) 3$ & $0.2490 \mathrm{E}-1$ & $\mathrm{~A} I(\mathrm{OH}) 3$ & 0.1833 & $\mathrm{Sr}(\mathrm{OH}) 2$ & $0.2000 \mathrm{E}-3$ \\
\hline C6H6 & 0 & C6H5OH & 0 & $\mathrm{CsOH}$ & 0 \\
\hline $\mathrm{KOH}$ & 0 & CsTPB & 0 & NaTPB & 0 \\
\hline NaDPB & 0 & KTPB & 0 & NH4TPB & 0 \\
\hline MST & $0.1190 \mathrm{E}-1$ & MSTSr & 0 & MSTU & 0 \\
\hline$(\mathrm{C} 6 \mathrm{H} 5) 3 \mathrm{~B}$ & 0 & $(\mathrm{C} 6 \mathrm{H} 5) 2 \mathrm{BOH}$ & 0 & $(\mathrm{C} 6 \mathrm{H} 5) \mathrm{B}(\mathrm{OH}) 2$ & 0 \\
\hline $\mathrm{B}(\mathrm{OH}) 3$ & 0 & $\mathrm{~K} 2 \mathrm{O}$ & $0.1000 \mathrm{E}-1$ & Li20 & 0 \\
\hline $\mathrm{MgO}$ & $0.5970 \mathrm{E}-1$ & Mno & $0.2600 \mathrm{E}-2$ & TiO2 & 0 \\
\hline U308 & 0 & ZrO2 & 0 & Ca3P2O8 & 0.2268 \\
\hline P205 & $0.7000 \mathrm{E}-3$ & $\mathrm{Cr} 2 \mathrm{O} 3$ & 0 & $\mathrm{Cs} 2 \mathrm{O}$ & 0 \\
\hline CuO & 0 & $\mathrm{Na} 2 \mathrm{O}$ & $0.3000 \mathrm{E}-3$ & NiO & 0 \\
\hline SiO2 & 0.4755 & $\mathrm{HgO}$ & 0 & PuO2 & 0 \\
\hline $\mathrm{CaCO} 3$ & 0 & $\mathrm{Na} 2 \mathrm{CO} 3$ & 0 & $\mathrm{Na} 2 \mathrm{SO} 4$ & $0.5000 \mathrm{E}-2$ \\
\hline
\end{tabular}

7. Grout Flow and Composition Grout Flow $25.2891 \mathrm{klb} / \mathrm{hr}$

\begin{tabular}{|c|c|c|c|c|c|}
\hline $\mathrm{H} 2 \mathrm{O}$ & 0.3176 & Salt & $0.2191 \mathrm{E}-2$ & NaNO3 & $0.6138 \mathrm{E}-1$ \\
\hline NaNo2 & $0.1072 \mathrm{E}-1$ & $\mathrm{NaOH}$ & $0.3050 \mathrm{E}-1$ & KNO3 & $0.5442 \mathrm{E}-4$ \\
\hline CsNo3 & 0 & NH4NO3 & $0.4284 \mathrm{E}-5$ & $\mathrm{NH} 4 \mathrm{OH}$ & 0 \\
\hline $\mathrm{NaAlO} 2$ & $0.8117 \mathrm{E}-2$ & Sludge & 0.0 & $\mathrm{Na} 2 \mathrm{U} 207$ & $0.2237 \mathrm{E}-6$ \\
\hline $\mathrm{Fe}(\mathrm{OH}) 3$ & $0.1387 \mathrm{E}-1$ & $\mathrm{~A} I(\mathrm{OH}) 3$ & 0.1021 & $\mathrm{Sr}(\mathrm{OH}) 2$ & $0.1114 \mathrm{E}-3$ \\
\hline $\mathrm{C} 6 \mathrm{H} 6$ & 0 & $\mathrm{C} 6 \mathrm{H} 5 \mathrm{OH}$ & 0 & $\mathrm{CsOH}$ & $0.8376 \mathrm{E}-5$ \\
\hline $\mathrm{KOH}$ & $0.4246 \mathrm{E}-3$ & CsTPB & 0 & NaTPB & 0 \\
\hline NaDPB & 0 & KTPB & 0 & NH4TPB & 0 \\
\hline MST & $0.6630 \mathrm{E}-2$ & MSTSr & 0 & MSTU & 0.0 \\
\hline (C6H5) 3B & 0 & (C6H5) $2 \mathrm{BOH}$ & 0 & $(\mathrm{C} 6 \mathrm{H} 5)$ B $(\mathrm{OH}) 2$ & 0 \\
\hline $\mathrm{B}(\mathrm{OH}) 3$ & 0 & K2O & $0.5572 \mathrm{E}-2$ & Li20 & 0 \\
\hline Mgo & $0.3326 \mathrm{E}-1$ & Mno & $0.1449 E-2$ & Tio2 & 0 \\
\hline U308 & 0 & $\mathrm{ZrO2}$ & 0 & Ca3P208 & 0.1264 \\
\hline P205 & $0.3900 \mathrm{E}-3$ & $\mathrm{Cr} 2 \mathrm{O} 3$ & 0 & $\mathrm{Cs} 2 \mathrm{O}$ & 0 \\
\hline Cuo & 0 & $\mathrm{Na} 2 \mathrm{O}$ & $0.1672 \mathrm{E}-3$ & NiO & 0 \\
\hline $\mathrm{SiO} 2$ & 0.2649 & HgO & $0.1629 E-4$ & PuO2 & 0 \\
\hline $\mathrm{CaCO} 3$ & 0 & $\mathrm{Na} 2 \mathrm{CO} 3$ & $0.6627 \mathrm{E}-2$ & $\mathrm{Na} 2 \mathrm{SO}_{4}$ & $0.7966 \mathrm{E}-2$ \\
\hline
\end{tabular}




\subsection{DWPF Model Results for Direct Disposal in Grout Process}

The following table lists summary results from the DWPF calculation for the Direct Disposal in Grout process. Mass and volume results for the various flow streams and can production are yearly averages based on about 20 batch cycles in DWPF. The second section shows the instantaneous flow stream compositions throughout the model at the end of the run.

\section{Report SUMMARY}

$\begin{array}{crl}\text { Problem time : } 3000.0 \mathrm{hr}= & 0.342 \mathrm{yr} \\ \text { Integration interval } & 0.274 \mathrm{yr} \\ \text { Can production: } & 426.174 \text { per year } \\ \text { Glass properties: } & & \\ \text { Durability: } & -7.349 & \\ \text { Viscosity: } & 38.383 & \\ \text { Liquidus: } & 1006.437 & \\ \text { Percent CST: } & & \\ \text { Effective } & 2.109 & \\ \text { Percent_Ti: } & 3209.318 \mathrm{kgal} / \mathrm{yr} \\ \text { Recycle volume: } & 54.757 \mathrm{klbm} / \mathrm{yr} \\ \text { NO2: } & & \end{array}$

PROCESS SUMMARY

$\begin{array}{cl}\text { Chemical Processing Cell (SRAT, } \\ \text { Item } & \\ 80 & \text { Sludge to SRAT } \\ 81 & \text { Salt to SRAT } \\ 82 & \text { MST to SRAT } \\ 83 & \text { Formic to SRAT } \\ 84 & \text { Nitric acid to SRAT } \\ 85 & \text { NaNO2 to RCT } \\ 86 & \text { Caustic to RCT } \\ 87 & \text { Recycle H2O to TnkFrm } \\ 88 & \text { SRAT condensate } \\ 89 & \text { SME condensate } \\ 90 & \text { Offgas condensate } \\ 91 & \text { Melter feed } \\ 92 & \text { SME to MFT } \\ 93 & \text { Formic to SME } \\ 94 & \text { SME Redox number } \\ 95 & \text { Process frit to SME } \\ 96 & \text { Decon frit to SME } \\ 97 & \text { Process dryfrit to SME } \\ 98 & \text { Decon dryfrit to SME } \\ 99 & \text { SRAT to SME } \\ 100 & \text { RRBT (Salt) to SRAT } \\ 101 & \text { Glass } \\ & \end{array}$

SME, MFT $)$
Mass $(\mathrm{k} 1 \mathrm{~b} / \mathrm{yr})$
3626.445
0.631
2788.886
114.122
146.920
207.874
1074.487
26994.229
0.604
0.337

3783.087
3928.687
76.081

1682.467
1555.465
996.340
72.998
3071.421
0.631
1682.736

Volume (Kgal/yr)
395.816
0.076
313.783
11.497
14.717
19.613
94.946
3209.318


327.774
395.478
7.665
136.660
182.531

337.721
0.076
76.703




\section{Report MASSFRACTION}

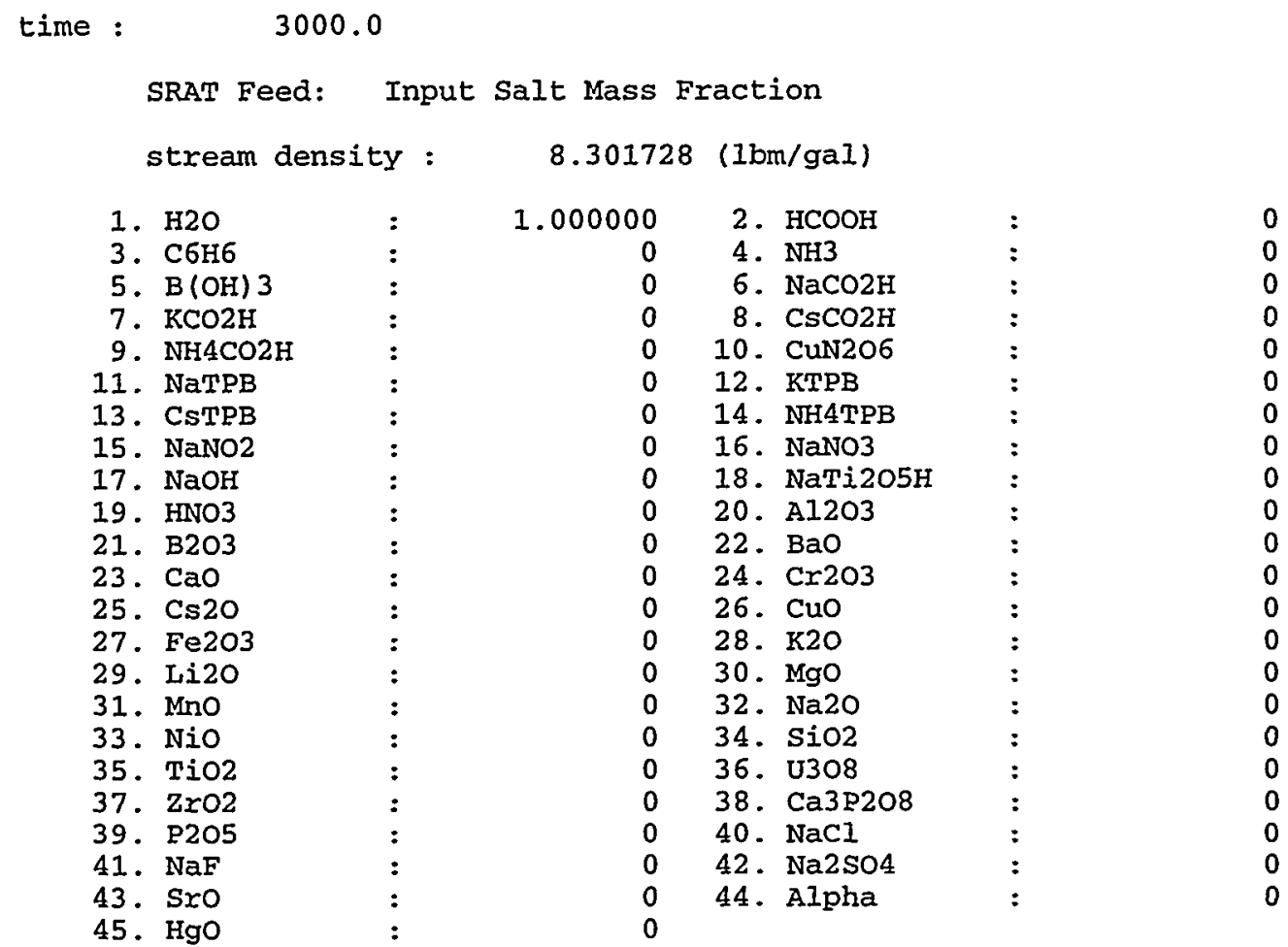

SRAT Feed: Alpha Decontamination stream stream density : 8.748535 (1 $\quad 8 \mathrm{bm} / \mathrm{gal})$

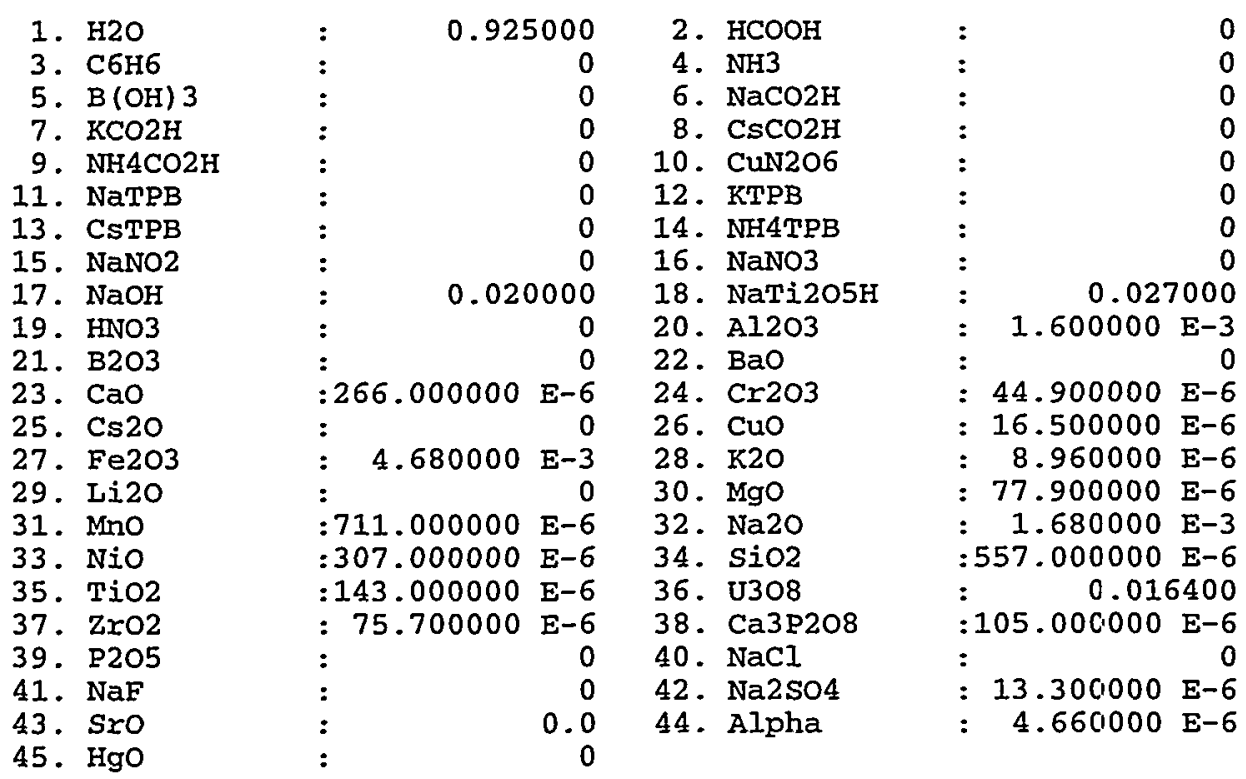


SRAT Feed: Sludge Input Mass Fractions stream density : $\quad 9.138866(1 \mathrm{bm} / \mathrm{gal})$

\begin{tabular}{|c|c|c|c|c|}
\hline 1. $\mathrm{H} 2 \mathrm{O}$ & 0.875 & 9010 & 2. $\mathrm{A} 1203$ & 0.016910 \\
\hline 3. $\mathrm{B} 2 \mathrm{O} 3$ & : & 0 & 4. $\mathrm{BaO}$ & 0 \\
\hline 5. $\mathrm{CaO}$ & 2.813900 & E-3 & 6. Cr203 & $: 474.480000 \quad E-6$ \\
\hline 7. $\mathrm{Cs} 2 \mathrm{O}$ & : & 0.0 & 8. CuO & $: 174.360000 \mathrm{E}-6$ \\
\hline 9. $\mathrm{Fe} 203$ & 0.045 & 9460 & 10. $\mathrm{K} 2 \mathrm{O}$ & $=94.623000 \mathrm{E}-6$ \\
\hline 11. Li20 & $:$ & 0 & 12. MgO & $: 822.780000 \mathrm{E}-6$ \\
\hline 13. $\mathrm{MnO}$ & 7.519400 & E-3 & 14. Na2O & 0.017450 \\
\hline 15. NiO & 3.245200 & E-3 & 16. SiO2 & $5.883500 \mathrm{E}-3$ \\
\hline 17. TiO2 & $: 10.731000$ & $\mathrm{E}-6$ & 18. U308 & 0.010520 \\
\hline 19. ZrO2 & $: 800.920000$ & $E-6$ & 20. Са3Р208 & $1.105700 \mathrm{E}-3$ \\
\hline 21. $\mathrm{P} 205$ & : & 0 & 22. $\mathrm{NaCl}$ & \\
\hline 23. $\mathrm{NaF}$ & : & 0 & 24. $\mathrm{Na} 2 \mathrm{SO} 4$ & $: 141.040000 \mathrm{E}-6$ \\
\hline 25. Sro & : & 0.0 & 26. Alpha & $: 49.177000$ E-6 \\
\hline 7. $\mathrm{HgO}$ & 3.513200 & $E-3$ & & \\
\hline
\end{tabular}

SRAT : Output Mass Fractions

$$
\text { stream density : } \quad 9.094555 \text { (1bm/gal) }
$$

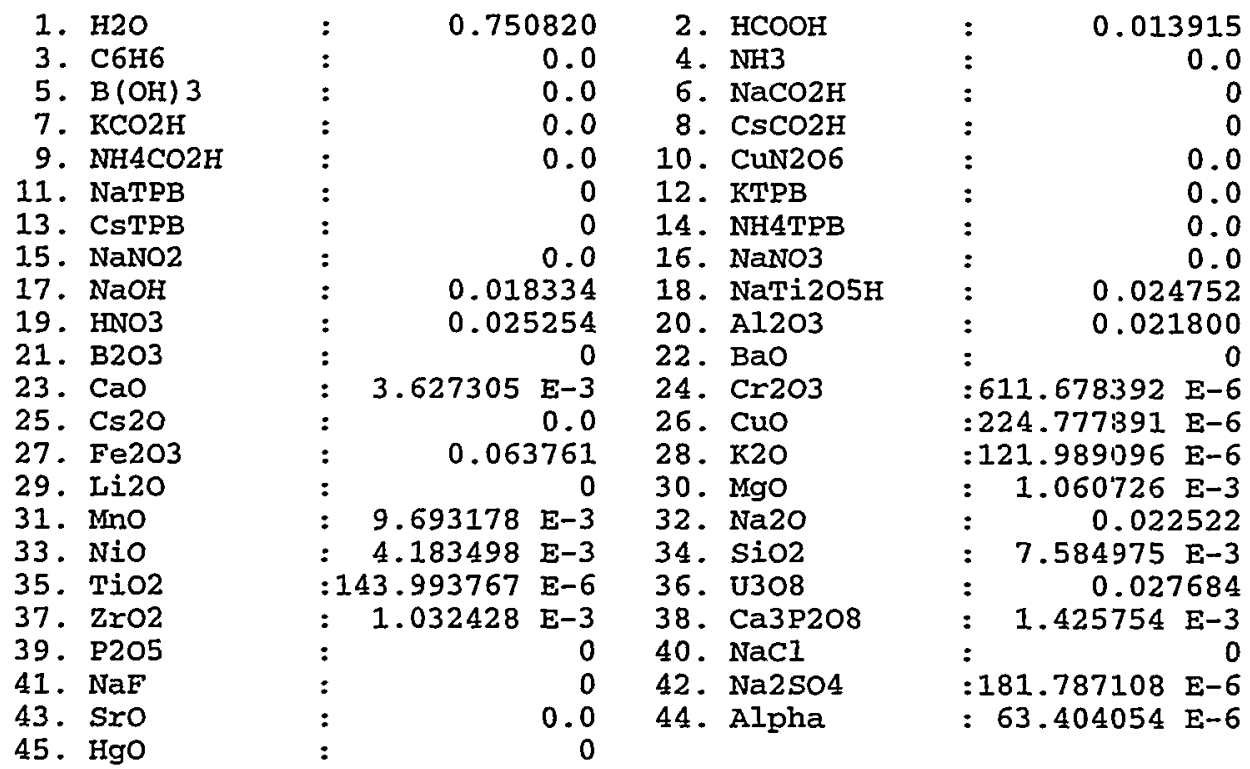

SME : Output Mass Fractions

$$
\text { stream density : } \quad 9.934030 \text { (1bm/gal) }
$$

\begin{tabular}{|c|c|c|c|c|c|c|}
\hline 1. $\mathrm{H} 2 \mathrm{O}$ & $:$ & 0.515687 & 2. $\mathrm{HCOOH}$ & $:$ & 0.014 & 4469 \\
\hline 3. c $6 \mathrm{H} 6$ & : & -0.0 & 4. $\mathrm{NH} 3$ & $:$ & & 0.0 \\
\hline $\mathrm{B}(\mathrm{OH}) 3$ & : & $3.676647 \mathrm{E}-6$ & 6. $\mathrm{NaCO} 2 \mathrm{H}$ & : & & 0 \\
\hline $\mathrm{KCO} 2 \mathrm{H}$ & : & $3.970718 E-6$ & 8. $\mathrm{CsCO} 2 \mathrm{H}$ & : & & 0 \\
\hline $\mathrm{NH} 4 \mathrm{CO} 2 \mathrm{H}$ & : & 0.0 & 10. Cun206 & : & 1.484 .668 & $\mathrm{E}-6$ \\
\hline NaTpB & : & 0 & 12. KTPB & : & & 0.0 \\
\hline CsTPB & : & 0 & 14. NH4TPB & : & & 0.0 \\
\hline NaNO2 & : & 0.0 & 16. NaNO3 & : & & 0.0 \\
\hline $\mathrm{NaOH}$ & : & 0.014382 & 18. NaTi205H & : & 0.019 & 9418 \\
\hline HNO3 & : & 0.019816 & 20. A1203 & : & 0.017 & 7108 \\
\hline $\mathrm{B} 203$ & 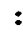 & 0.034223 & 22. BaO & : & & 0 \\
\hline $\mathrm{CaO}$ & : & $2.846601 \mathrm{E}-3$ & 24. Cr2O3 & $:$ & 80.0141038 & $\mathbf{E}-6$ \\
\hline $\mathrm{Cs} 2 \mathrm{O}$ & : & 0.0 & 26. CuO & & .76 .402148 & $E-6$ \\
\hline Fe203 & : & 0.050037 & 28. $\mathrm{K} 2 \mathrm{O}$ & : & 95.732325 & E-6 \\
\hline Li20 & : & 0.014263 & 30. $\mathrm{MgO}$ & : & 6.535534 & $\mathbf{E}-3$ \\
\hline $\mathrm{MnO}$ & : $1+3010+$ & $7.606907 \mathrm{E}-3$ & 32. $\mathrm{Na} 2 \mathrm{O}$ & : & 0.049 & 9045 \\
\hline $\mathrm{NiO}$ & : & $3.283185 \mathrm{E}-3$ & 34. SiO2 & : & D. 205 & 5602 \\
\hline
\end{tabular}




$\begin{array}{llrllr}\text { 35. TiO2 } & : 112.951417 & \mathrm{E}-6 & 36 . \mathrm{U} 308 & : & 0.021722 \\ \text { 37. ZrO2 } & : 810.213416 & \mathrm{E}-6 & 38 . \mathrm{Ca} 3 \mathrm{P} 208 & : & 1.118840 \mathrm{E}-3 \\ \text { 39. P2O5 } & : & 0 & 40 . \mathrm{NaCl} & : & 0 \\ \text { 41. NaF } & : & 0 & 42 . \text { Na2SO4 } & : 142.7416 .27 \mathrm{E}-6 \\ \text { 43. SrO } & : & 0.0 & 44 . \text { Alpha } & : \text { 49.7727.55 E-6 } \\ \text { 45. HgO } & : & 0 & & & \end{array}$

MFT : Output Mass Fractions

stream density : 11.541768 (Ibm/gal)

\begin{tabular}{|c|c|c|c|c|c|c|}
\hline 1. $\mathrm{H} 2 \mathrm{O}$ & 0.515 & 5692 & 2. $\mathrm{HCOOH}$ & : & 0.014 & 4468 \\
\hline 3. $\mathrm{C} 6 \mathrm{H} 6$ & : & 0.0 & 4. $\mathrm{NH3}$ & : & & 0.0 \\
\hline 5. $\mathrm{B}(\mathrm{OH}) 3$ & : & 0.0 & 6. $\mathrm{NaCO} 2 \mathrm{H}$ & : & & 0.0 \\
\hline 7. $\mathrm{KCO} 2 \mathrm{H}$ & : & 0.0 & 8. $\mathrm{CsCO} 2 \mathrm{H}$ & : & & 0.0 \\
\hline 9. $\mathrm{NH} 4 \mathrm{CO} 2 \mathrm{H}$ & : & 0.0 & 10. CuN206 & : & & 0.0 \\
\hline 11. NaTPB & : & 0 & 12. KTPB & : & & 0.0 \\
\hline 13. CsTPB & : & 0 & 14. NH4TPB & : & & 0.0 \\
\hline 15. NaNO2 & : & 0.0 & 16. NaNO3 & : & & 0.0 \\
\hline 17. $\mathrm{NaOH}$ & 0.014 & 4397 & 18. NaTi205H & : & 0.019 & 9436 \\
\hline 19. $\mathrm{HNO} 3$ & 0.019 & 9821 & 20. AI203 & : & 0.017 & 7108 \\
\hline 21. $\mathrm{B} 203$ & 0.034 & 4220 & 22. $\mathrm{BaO}$ & : & & 0 \\
\hline 23. $\mathrm{CaO}$ & 2.846668 & $\mathbf{E}-3$ & 24. Cr203 & & 80.039212 & $E-6$ \\
\hline 25. Cs20 & : & 0.0 & 26. CuO & & 176.4031 .14 & $E-6$ \\
\hline $\mathrm{Fe} 2 \mathrm{O} 3$ & 0.050 & 0039 & 28. K2O & : & 95.735844 & $E-6$ \\
\hline 29. I 220 & 0.014 & 4261 & 30. $\mathrm{MgO}$ & : & 6.534877 & $E-3$ \\
\hline Mno & 7.607097 & $E-3$ & 32. Na2O & : & 0.049 & 9043 \\
\hline $\mathrm{NiO}$ & 3.283155 & $E-3$ & 34. SiO2 & : & 0.205 & 5576 \\
\hline 35. TiO2 & $: 113.065918$ & $E-6$ & 36. U308 & : & 0.021 & 1732 \\
\hline $\mathrm{ZrO2}$ & $: 810.238425$ & $E-6$ & 38. Ca3P208 & : & 1.118920 & $E-3$ \\
\hline P205 & $:$ & 0 & 40. $\mathrm{NaCl}$ & : & & 0 \\
\hline $\mathrm{NaF}$ & : & 0 & 42. Na2 $2 \mathrm{SO}_{4}$ & & 42.658940 & $E-6$ \\
\hline Sro & : & 0.0 & 44. Alp̌ha & : & 49.757776 & E-6 \\
\hline $\mathrm{HgO}$ & : & 0 & & & & \\
\hline
\end{tabular}

MELTER Output Mass Fractions

MELTER Output density:

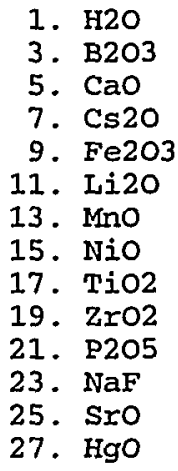

$21.938327 \mathrm{Ibm} / \mathrm{gal}$

$\begin{array}{rl}0 & 2 . \mathrm{Al2O} \\ 0.076909 & 4 . \mathrm{BaO} \\ 6.398310 \mathrm{E}-3 & 6 . \mathrm{Cr} 2 \mathrm{O3} \\ 0.0 & 8 . \mathrm{CuO} \\ 0.112471 & 10 . \mathrm{K} 20 \\ 0.032051 & 12 . \mathrm{MgO} \\ 0.017098 & 14 . \mathrm{Na} 2 \mathrm{O} \\ 7.379380 \mathrm{E}-3 & 16 . \mathrm{SiO} 2 \\ 0.035172 & 18 . \mathrm{U} 308 \\ 1.821132 \mathrm{E}-3 & 20 . \mathrm{Ca} \mathrm{P} 208 \\ 0 & 22 . \mathrm{NaCl} \\ 0 & 24 . \mathrm{Na} 2 \mathrm{SO} 4 \\ 0.0 & 26 . \mathrm{Alpha} \\ 0 & \end{array}$

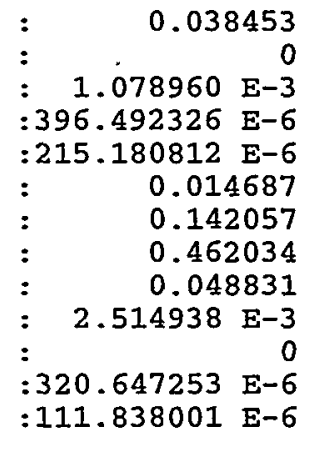

Recycle Mass Fractions

stream density : $\quad 8.411203$ (Ibm/gal)

\begin{tabular}{|c|c|c|c|}
\hline 1. $\mathrm{H} 2 \mathrm{O}$ & $:$ & 0.972625 & 2. $\mathrm{CO} 2 \mathrm{H} 2$ \\
\hline 3. $\mathrm{C} 6 \mathrm{H} 6$ & $:$ & 0.0 & 4. NH3 \\
\hline 5. ВО3 $\mathrm{H} 3$ & : & 0 & 6. $\mathrm{NaCO} 2 \mathrm{H}$ \\
\hline 7. $\mathrm{KCO} 2 \mathrm{H}$ & : & 0 & 8. $\mathrm{CsCO} 2 \mathrm{H}$ \\
\hline 9. $\mathrm{NH} 4 \mathrm{CO} 2 \mathrm{H}$ & $:$ & 0 & 10. CuN206 \\
\hline NaTPB & : & 0 & 12. KTPB \\
\hline CsTPB & : & 0 & 14. NH4TPB \\
\hline NaNO2 & $:$ & $3.082648 \mathrm{E}-3$ & 16. NaNO3 \\
\hline $\mathrm{NaOH}$ & : & 0.019915 & \\
\hline
\end{tabular}

$4.377542 \quad E-3$
0.0
0
0
0
0
0
0




\section{NOMENCLATURE}

\begin{tabular}{ll} 
AST & Alpha Sorption Tank \\
CIF & Consolidated Incineration Facility \\
CPES & Chemical Process Evaluation System \\
CPU & Central Processing Unit \\
CST & Crystalline Silicotitanate \\
DWPF & Defense Waste Processing Facility \\
EDI & External Data Interface \\
ESP & Extended Sludge Processing \\
ETF & Effluent Treatment Facility \\
FY & Fiscal Year \\
GMC & Glass Melter Condenser \\
HLW & High Level Waste \\
HLWIFM & High Level Waste Integrated Flowsheet Model \\
IFM & Integrated Flowsheet Model \\
ITP & InTank Precipation \\
IX & Ion Exchanger \\
MFT & Melter Feed Tank \\
MST & Monosodium Titanate \\
OE & Organic Evaporator \\
OWST & Organic Waste Storage Tank \\
PCCS & Process Composition and Control System \\
PR & Precipitate Reactor \\
PRBT & Precipitate Reactor Bottoms Tank \\
PRCD & Precipitate Reactor Condenser and Decanter \\
RCT & Recycle Collection Tank \\
RHLWE & Replacement High Level Waste Evaporator \\
SAS & Steam Atomized Scrubber \\
SME & Slurry Mix Evaporator \\
SMEC & Slurry Mix Evaporator Condenser \\
SRAT & Slurry Receipt and Adjustment Tank \\
SRATC & Slurry Receipt and Adjustment Tank Condenser \\
SRS & Savannah River Site \\
SRTC & Savannah River Technology Center \\
SSHT & Salt Solution Holding Tank \\
SSRT & Sludge Slurry Receipt Tank \\
STPB & Sodium Tetraphenylborate \\
TPB & Tetraphenylborate \\
WCS & Waste Composition System \\
& \\
\hline
\end{tabular}




\section{REFERENCES}

1.1 SPEEDUP “User Manual”, Aspen Technology, Inc., Cambridge, Massachusetts, 1993.

1.2 Beck, S. et al., Bases, Assumptions, and Results of the Flowsheet Calculations for the Initial Eighteen Salt Disposition Alternatives, WSRC-RP-98-00166, Revision 1.

1.3 Beck, S. et al., Bases, Assumptions, and Results of the Flowsheet Calculations for the Short List Salt Disposition Alternatives, WSRC-RP-98-00168, Revision 1, October 22, 1998.

2.1 Aull, J. E. et al., A Description of the High Level Waste Integrated Flowsheet Model (U), WSRCRP-94-567, Draft, September 1994.

2.2 Smith, III, F. G., "Modeling the Defense Waste Processing Facility with SPEEDUP," Advances in Environmental Research, 2 (3), 296-312, 1998.

2.3 Gregory, M. V. and Dimenna, R. A., "Parallel Computing Acceleration of the High Level Waste Integrated Flowsheet Model: First Quarterly Report," SRT-EMS-980001 (1998).

2.4 Dimenna, R. A. and Gregory, M. V., "Parallel Computing Acceleration of the High Level Waste Integrated Flowsheet Model: Second Quarterly Report," SRT-EMS-980007 (1998).

3.1 Hestèr, J. R., High Level Waste Characterization System (WCS), WSRC-TR-96-0264, Rev. 0, December 1996.

3.2 Smith, III, F. G., "A Simple Glass Blending Algorithm Including Uncertainties (U)," SRTCPCCA-96-0019, March 12, 1996.

4.1 M. V. Gregory and P. K. Paul, "Functional Overview of the Production Planning Model (ProdMod)," WSRC-TR-95-0386, Westinghouse Savannah River Company, September 1995.

4.2 N. R. Davis and M. N. Wells, "High Level Waste System Plan, Revision 9," HLW-OVP-970068, Westinghouse Savannah River Company, 1998.

4.3 J. M. Gillam, “DWPF Recycle Waste Generation Update (U)”, HLW-DEN-98-0012, February 10, 1998.

4.4 D. J. McCabe, Examination of Crystalline Silicotitanate Applicability in Removal of Cesium from SRS High Level Waste (U), WSRC-TR-97-0016, Rev. 0, April 1997.

4.5 D. D. Walker et al., Cesium Removal from Simulated SRS High-Level Waste Using Crystalline Silicotitanate (U), WSRC-TR-98-00344, Rev. 1, October 1998.

6.1 Leonard, R. A. and Regalbuto, M. C., "A Spreadsheet Algorithm for Stagewise Solvent Extraction," Solvent Extraction and Ion Exchange, 12(5), 909-930, 1994.

7.1 Bird, R.B., W.E. Stewart and E.N Lightfoot, Transport Phenomena, John Wiley \& Sons, 1960, pp. 702-705. 
7.2 Beck, S.B. “Ion Exchange Model for CST Column Sizing (U)," WSRC-RP-98-01953, September 1998.

7.3 Jacobs, R.A. "Inputs for CST SpeedUp Model," Memo to T. Hang dated 9/24/98. 


\section{APPENDIX}

Specifics of the above analyses may be found in the archived files in the Cray directory /archive/t4148/phaseIII/ small_tank, where the file edi_smalltank_0916.f contains the listing of the EDI logic, and the file small_fy2017_1001.speedup contains the complete model and input listing. 